\title{
The U.S. Geological Survey Peak-Flow File Data Verification Project, 2008-16
}
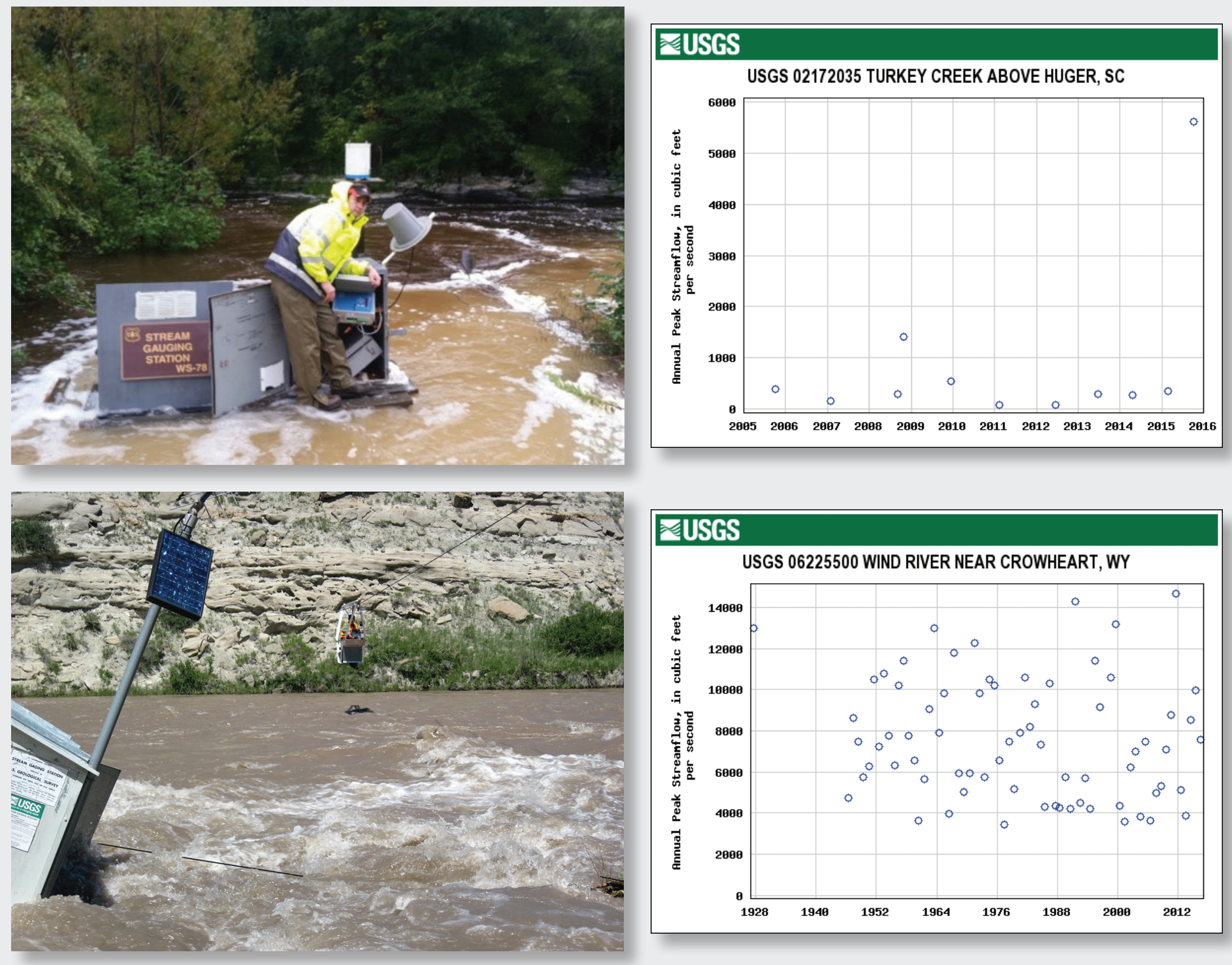

Scientific Investigations Report 2017-5119 
Front cover. Upper left:U.S. Geological Survey (USGS) hydrographer Chris Smith servicing streamgage 02172035, Turkey Creek above Huger, South Carolina, during flooding on October 4, 2015. Turkey Creek peaked the next day with a streamflow of 5,610 cubic feet per second ( $\left.\mathrm{ft}^{3} / \mathrm{s}\right)$ and the peak is qualified with a code 2, discharge is an estimate. Upper right: Plot of peak-flow values entries for streamgage 02172035 Turkey Creek above Huger, South Carolina. Lower left: USGS hydrographer Jerrod Wheeler (in cablecar) measures flood flows right before the gagehouse washes away; streamgage 06225500 Wind River near Crowheart, Wyoming, July 1, 2011; streamflow of 13,900 ft3 $/ \mathrm{s}$ (photograph by Glenn Laidlaw). The peak of record at this gage, $14,700 \mathrm{ft}^{3} / \mathrm{s}$, occurred the day before the photograph was taken. All of the peaks at this streamgage in the systematic period of record are qualified with a code 5 , discharge affected to unknown degree by regulation or diversion. Lower right: Plot of peak-flow values entries for streamgage 06225500 Wind River near Crowheart, Wyoming.

Back cover. Upper left: Equipment stored in a cooler and attached to a gage house roof in anticipation of a very large flood on the Souris River near Westhope, North Dakota, streamgage 05124000 , June 28,2011 . This was done to prevent failure of the electronics in the gage house. An electronics failure might result in having to qualify the peak with a code 8, discharge was actually greater than the indicated value (photograph by Nathan Stroh). Upper right: Plot of peak-flow values for streamgage 05124000 Souris River near Westhope, North Dakota. Lower left: USGS scientist Steve Hannes marking and measuring a high-water mark along the Colorado River after flooding from Harvey in Matagorda County, Texas, September 11, 2017 (photograph by Scott Green). 


\section{The U.S. Geological Survey Peak-Flow File Data Verification Project, 2008-16}

By Karen R. Ryberg, Burl B. Goree, Tara Williams-Sether, and

Robert R. Mason, Jr.

Scientific Investigations Report 2017-5119 


\title{
U.S. Department of the Interior \\ RYAN K. ZINKE, Secretary
}

\section{U.S. Geological Survey William H. Werkheiser, Acting Director}

\author{
U.S. Geological Survey, Reston, Virginia: 2017
}

For more information on the USGS - the Federal source for science about the Earth, its natural and living resources, natural hazards, and the environment-visit https://www.usgs.gov or call 1-888-ASK-USGS.

For an overview of USGS information products, including maps, imagery, and publications, visit https://store.usgs.gov.

Any use of trade, firm, or product names is for descriptive purposes only and does not imply endorsement by the U.S. Government.

Although this information product, for the most part, is in the public domain, it also may contain copyrighted materials as noted in the text. Permission to reproduce copyrighted items must be secured from the copyright owner.

Suggested citation:

Ryberg, K.R., Goree, B.B., Williams-Sether, Tara, and Mason, R.R., Jr., 2017, The U.S. Geological Survey Peak-Flow File Data Verification Project, 2008-16: U.S. Geological Survey Scientific Investigations Report 2017-5119, 61 p., https://doi.org/10.31333/sir20175119.

ISSN 2328-0328 (online) 


\section{Contents}

Abstract

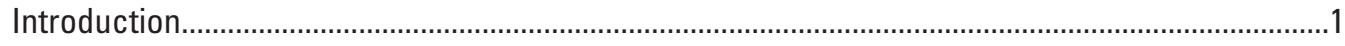

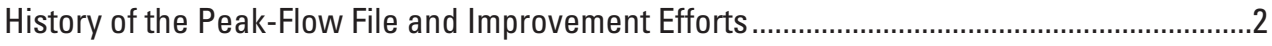

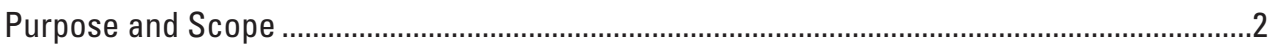

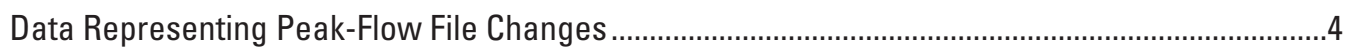

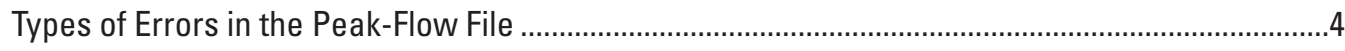

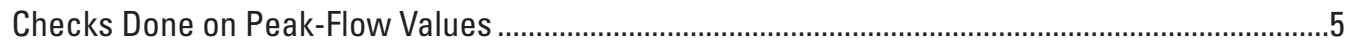

Peak Greater Than or Equal to Daily Mean Value (PGTDV).....................................................

Comparison to Annual Mean Values (AMV) ...............................................................................

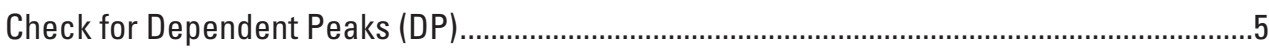

Linear Regression of Peak on Daily Mean Value (LRGPDV) .....................................................6

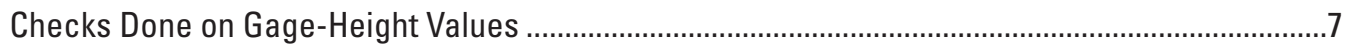

Check for Existence of Gage Height $(\mathrm{GH})$.................................................................................

Linear Regression of Gage Height on Peak Flow ................................................................

Peak-Flow File Qualification Codes ...............................................................................................

Peak-Flow Qualification Codes ..................................................................................................

Checks of the Peak-Streamflow Qualification Codes..................................................11

Check for Regulation Code Dropped after Initial Use (DropREG) ...........................11

Check for Missing Code 7 (Need7) ........................................................................11

Check for Incorrect Usage of Code 7 (Not7) ........................................................11

Check for Qualification of Inexact Dates (AB) ....................................................11

Check for Omission of Code C (DropC) .................................................................11

Information Reports................................................................................................11

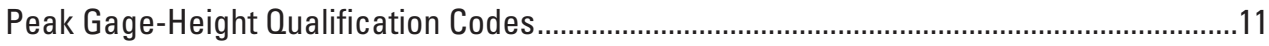

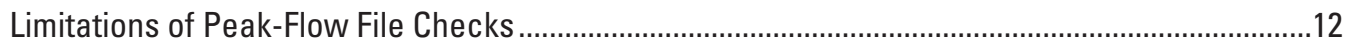

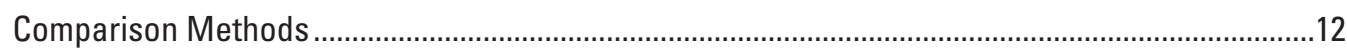

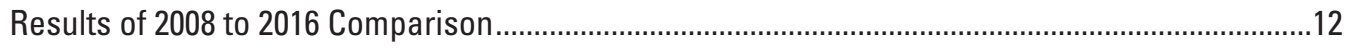

Changes to the Peak-Flow Value, Peak Date, or Peak-Flow Qualification Codes ...................13

Changes to the Gage Height or Gage-Height Qualification Codes...........................................13

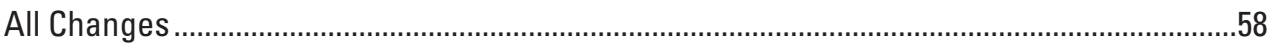

Summary

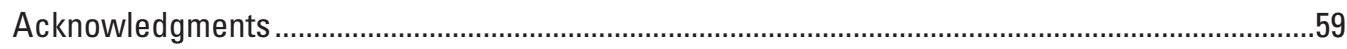

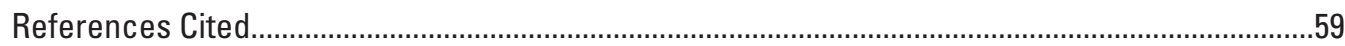

Appendix 1. U.S. Geological Survey Surface Water Branch Technical

Memorandum 69.11-Storage and Retrieval System for Annual

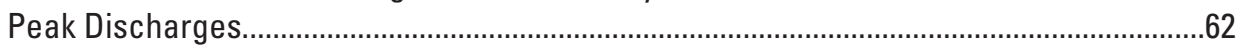

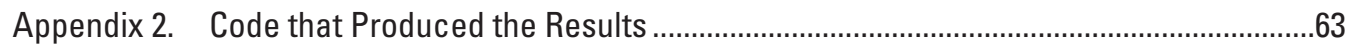

Reference Cited....................................................................................................................63 


\section{Figures}

1. Title pages from U.S. Geological Survey reports highlighting the history, geographic diversity, and uses of the peak-flow file.

2. Graph showing example of regression of peak streamflow on the daily mean values for the John Day River at McDonald Ferry, Oregon, U.S. Geological Survey streamgage 14048000 .

3. Graph showing example of regression of peak streamflow on the daily mean values for the Red River of the North, Fargo, North Dakota, U.S. Geological Survey streamgage 05054000 .

4. Cartograms of streamgages with absolute value of change in peak streamflow greater than 0 and less than or equal to 5 percent.

5. Cartograms of streamgages with absolute value of change in peak streamflow greater than 5 percent and less than or equal to 10 percent.

6. Cartograms of streamgages with absolute value of change in peak streamflow greater than 10 percent and less than or equal to 25 percent.

7. Cartograms of streamgages with absolute value of change in peak streamflow greater than 25 percent and less than or equal to 50 percent.

8. Cartograms of streamgages with absolute value of change in peak streamflow greater than 50 percent and less than or equal to 100 percent.

9. Cartograms of streamgages with increases in peak streamflow greater than 100 percent and less than or equal to 500 percent and change in peak streamflow greater than 500 percent and less than or equal to 1,000 percent.

10. Cartograms of streamgages with increases in peak streamflow greater than 1,000 percent and less than or equal to 5,000 percent and change in peak streamflow greater than 5,000 percent and less than or equal to 10,000 percent.

11. Cartograms of streamgages with percent change in peak streamflow greater than 10,000 percent and less than or equal to 50,000 percent and change in peak streamflow greater than 50,000 percent

12. Graph showing count of changes to peak-streamflow values by water year.

13. Cartograms indicating streamgages with peak-streamflow qualification code 1 removed or added

14. Cartograms indicating streamgages with peak-streamflow qualification code 2 removed or added.

15. Cartograms indicating streamgages with peak-streamflow qualification code 3 removed or added.

16. Cartograms indicating streamgages with peak-streamflow qualification code 4 removed or added.

17. Cartograms indicating streamgages with peak-streamflow qualification code 5 removed or added

18. Cartograms indicating streamgages with peak-streamflow qualification code 6 removed or added.

19. Cartograms indicating streamgages with peak-streamflow qualification code 7 removed or added 
20. Cartograms indicating streamgages with peak-streamflow qualification code 8 removed or added.

21. Cartograms indicating streamgages with peak-streamflow qualification code 9 removed or added.

22. Cartograms indicating streamgages with peak-streamflow qualification code $A$ removed or added.

23. Cartograms indicating streamgages with peak-streamflow qualification code $B$ removed or added.

24. Cartograms indicating streamgages with peak-streamflow qualification code $C$ removed or added.

25. Cartograms indicating streamgages with peak-streamflow qualification code D removed or added.

26. Cartograms indicating streamgages with peak-streamflow qualification code $E$ removed or added.

27. Graph showing count of changes to peak-streamflow qualification codes by water year.

28. Cartograms indicating streamgages with changes to peak date and changes to peak date and peak-streamflow qualification code

29. Graph showing count of changes to peak date by water year.

30. Cartogram indicating streamgages with changes to peak streamflow, peak date, and peak-streamflow qualification code.....

31. Cartograms indicating streamgages with gage height removed or added

32. Cartograms indicating streamgages for which gage height existed in 2008 and 2016, but values differed, and streamgages with changes to gage height and gage-height qualification code

33. Graph showing count of changes to gage height by water year

34. Cartograms indicating streamgages with gage-height qualification code 1 removed or added.

35. Cartograms indicating streamgages with gage-height qualification code 2 removed or added.

36. Cartograms indicating streamgages with gage-height qualification code 3 removed or added.

37. Cartograms indicating streamgages with gage-height qualification code 4 removed or added.....

38. Cartograms indicating streamgages with gage-height qualification code 5 removed or added.

39. Cartograms indicating streamgages with gage-height qualification code 6 removed

40. Graph showing count of changes to gage-height qualification codes by water year

41. Graph showing count of changes to peak streamflow, peak date, peak-streamflow qualification code, gage height, or gage-height qualification code by water year 


\section{Tables}

1. Peak-streamflow qualification codes used in the U.S. Geological Survey National Water Information System.

2. Peak-streamflow qualification codes used by the U.S. Geological Survey program PeakFO

3. Gage-height qualification codes used in the U.S. Geological Survey National Water Information System

4. Peak streamflows with percent change in peak-streamflow value greater than 1,000 percent and less than or equal to 5,000 percent.

5. Peak streamflows with percent change in peak-streamflow value greater than 5,000 percent and less than or equal to 10,000 percent.

6. Peak streamflows with percent change in peak-streamflow value greater than 10,000 percent and less than or equal to 50,000 percent

7. Peak streamflows with percent change in peak-streamflow value greater than 50,000 percent .

8. Peak streamflows with qualific ation code 3 removed ……..........................................31

9. Peak streamflows with qualification code A removed .......................................................39

10. Peak streamflows with qualification code $D$ removed

\section{Conversion Factors}

U.S. customary units to International System of Units

\begin{tabular}{lcl}
\hline \multicolumn{1}{c}{ Multiply } & By & \multicolumn{1}{c}{ To obtain } \\
\hline foot $(\mathrm{ft})$ & Length & \\
\hline & 0.3048 & meter $(\mathrm{m})$ \\
\hline cubic foot per second $(\mathrm{ft} / \mathrm{s})$ & Flow rate & \\
\hline & 0.02832 & cubic meter per second $\left(\mathrm{m}^{3} / \mathrm{s}\right)$ \\
\hline acre-foot per square mile $\left(\right.$ acre-ft $\left./ \mathrm{mi}^{2}\right)$ & 476.2 & cubic meters per square $\mathrm{kilometer}\left(\mathrm{m}^{3} / \mathrm{km}^{2}\right)$ \\
\hline
\end{tabular}

\section{Supplemental Data}

A water year is the 1-year period that begins 0 ctober 1 and ends September 30 and is designated by the calendar year in which the period ends. 


\section{Abbreviations}

$\begin{array}{ll}\text { cSV } & \text { comma separated values } \\ \text { DV } & \text { daily mean value } \\ \text { EMA } & \text { Expected Moments Algorithm } \\ \text { GH } & \text { gage height } \\ \text { NWIS } & \text { National Water Information System } \\ \text { OSW } & \text { Office of Surface Water } \\ \text { PFF } & \text { peak-flow file } \\ \text { USGS } & \text { U.S. Geological Survey } \\ \text { WRD } & \text { Water Resources Division } \\ \text { WSC } & \text { Water Science Center }\end{array}$





\title{
The U.S. Geological Survey Peak-Flow File Data Verification Project, 2008-16
}

\author{
By Karen R. Ryberg, Burl B. Goree, Tara Williams-Sether, and Robert R. Mason, Jr.
}

\section{Abstract}

Annual peak streamflow (peak flow) at a streamgage is defined as the maximum instantaneous flow in a water year. A water year begins on October 1 and continues through September 30 of the following year; for example, water year 2015 extends from October 1, 2014, through September 30, 2015. The accuracy, characterization, and completeness of the peak streamflow data are critical in determining floodfrequency estimates that are used daily to design water and transportation infrastructure, delineate flood-plain boundaries, and regulate development and utilization of lands throughout the United States and are essential to understanding the implications of climate and land-use change on flooding and high-flow conditions.

As of November 14, 2016, peak-flow data existed for 27,240 unique streamgages in the United States and its territories. The data, collectively referred to as the "peak-flow file," are available as part of the U.S. Geological Survey (USGS) public web interface, the National Water Information System, at https://nwis.waterdata.usgs.gov/usa/nwis/peak. Although the data have been routinely subjected to periodic review by the USGS Office of Surface Water and screening at the USGS Water Science Center level, these data were not reviewed in a national, systematic manner until 2008 when automated scripts were developed and applied to detect potential errors in peak-flow values and their associated dates, gage heights, and peak-flow qualification codes, as well as qualification codes associated with the gage heights. USGS scientists and hydrographers studied the resulting output, accessed basic records and field notes, and corrected observed errors or, more commonly, confirmed existing data as correct.

This report summarizes the changes in peak-flow file data at a national level, illustrates their nature and causation, and identifies the streamgages affected by these changes. Specifically, the peak-flow data were compared for streamgages with peak flow measured as of November 19, 2008 (before the automated scripts were widely applied) and on November 14, 2016 (after several rounds of corrections). There were 659,332 peak-flow values in the 2008 dataset and 731,965 peak-flow values in the 2016 dataset. When compared to the 2016 dataset, 5,179 ( 0.79 percent) peak-flow values had changed; 36,506 (5.54 percent) of the peak-flow qualification codes had changed; 1,938 ( 0.29 percent $)$ peak-flow dates had changed; 18,599 ( 2.82 percent) of the peak-flow gage heights had changed; and 20,683 (3.14 percent) of the gage-height qualification codes had changed - most as a direct result of the peak-flow file data verification effort led by USGS personnel. The various types of changes are summarized and mapped in this report. In addition to this report, a corresponding USGS data release is provided to identify changes in peak flows at individual streamgages. The data release and the procedures to access the data release are described in this report.

\section{Introduction}

Annual peak streamflow (peak flow) at a streamgage (a point on a stream where streamflow is systematically monitored) is defined as the maximum instantaneous flow in a water year. A water year begins on October 1 and continues through September 30 of the following year; for example, water year 2015 extends from October 1, 2014, through September 30, 2015. This definition of a water year is used because it most often results in higher flows in the middle of the year and lower flows at the beginning and end of the year. Peak flows can range from zero flow in very dry basins to flows that barely exceed the natural streambanks and have small effects on ecosystems or property to flows that inundate vast areas beyond the flood plain and can cause extensive damage.

Peak-flow frequency estimates are used daily to design water and transportation infrastructure, delineate flood-plain boundaries, and regulate development and utilization of lands throughout the Nation and are essential to understanding the implications of climate and land-use change on flooding and high-flow conditions. Accuracy, characterization, and completeness of the U.S. Geological Survey (USGS) peak-flow file (PFF) data are critical to quality flood-frequency estimates. Data in the PFF are available as part of the USGS National Water Information System (NWIS) at https://nwis.waterdata. usgs.gov/usa/nwis/peak (U.S. Geological Survey, 2017b). This high-profile database reflects and highlights the broad utility of USGS water-data collection programs. As of November 14,2016 , a total of 731,965 entries of peak flow have been made in the USGS PFF for 27,240 unique streamgages in the 
United States and its territories for periods of record from 1 to 176 years (U.S. Geological Survey, 2017b). A primer on streamgaging with an emphasis on annual peak flow and the PFF is available in appendix 1 of Asquith and others (2017).

Although the peak-flow data have been routinely subjected to periodic review by the USGS Office of Surface Water (OSW) and screening at the USGS Water Science Center (WSC) level, these data were not reviewed in a national, systematic manner until 2008 when a computer program, PFReports (Ryberg, 2008), was developed to facilitate efficient and thorough review and correction of data. Checks embedded in the program were recommended as part of a more comprehensive assessment of peak-flow data that might also include examination of possible geographic or temporal variations in flood magnitude, timing, and frequency. Among other benefits, cleaning up the database may improve at-site flood-frequency estimates for specific locations and increase the likelihood of more accurate regional flood-frequency equations. Graphical and numerical examples of the checks and examples of specific errors are in Ryberg (2008).

\section{History of the Peak-Flow File and Improvement Efforts}

The USGS mission is to provide reliable, impartial, timely information that is needed to understand the water resources in the Nation. The compilation of information about the location, extent, quality, and flux of water in the United States is an essential element of this mission. The USGS operates an extensive network of streamgages (over 8,000 in 2017, U.S. Geological Survey, 2017a) that monitor streamflow through the full range of hydrologic conditions including droughts and floods, as well as thousands of partial-record streamgages that focus on specific flow regimes (such as annual peak flows). The resulting records, generally including a listing of annual peak-flow values, were summarized and published in several USGS publications dating from 1906 to 1960 (examples in fig. 1). In the 1960s, the annual peak-flow data, their dates, gage heights, and qualifying information and limitations, as well as supplementary peak flows, were compiled into a series of USGS water-supply papers (Barnes and Golden, 1966; Green, 1964; Patterson, 1966; Patterson and Gamble, 1968; Speer and Gamble, 1964a; Speer and Gamble, 1964b; Speer and Gamble, 1965; Tice, 1968; Wiitala, 1965).

In 1969, data contained in these publications were entered into a computer database (Roland Carter, U.S. Geological Survey, written commun., 1969; appendix 1). This database and its successors have been supplemented with the entry of additional peak flows published in annual water-data reports from 1960 to 2012 (use search term 'wdr' at https://pubs.er.usgs.gov/; one example is shown in fig. 1). Limitations of the computer storage technology in 1969 required substantial compression of the qualifying information into single character letters and numbers, which often failed to fully and unambiguously convey the circumstances that limit the full utility of some of the data or the special circumstances through which they were obtained. More complete information may be available in the USGS publications cited above as well as in the unpublished station records maintained by the USGS offices servicing the streamgages.

As with any other database, the PFF has been subject to a variety of human errors. Over the years, local and regional PFF data verification efforts have been made, usually prompted by State-level flood-frequency regionalization studies (such as the one for Alaska in fig. 1; Curran and others, 2016). These efforts were subject to individual interpretation of qualification codes and were completed on a piecemeal basis, only addressing those streamgages used within specific studies. In addition, investigators faced several challenges that included a cumbersome user interface, a lack of tools for efficiently detecting errors, inadequately articulated definitions for qualification codes, and insufficient guidance for resolving a variety of issues related to documenting annual peak flows.

In 2008, a PFF data verification project, which applied systematic and consistent screening methods to identify questionable data, began (PFReports; Ryberg, 2008). The effort also involved a new user interface, PKEntry, to facilitate corrections and document the changes and the reasoning for changes (U.S. Geological Survey, 2008). These tools provided national guidance and a phased approach.

Webinars were given to WSC personnel on December 5, 2008, and on January 5, 2009, to explain the need to improve the PFF and acquaint them with the new tools for making these improvements. In conjunction with the webinars, the USGS OSW (a technical office, previously called the Surface Water Branch, that, through fiscal year 2017, provided national leadership in the science of surface-water hydrology, hydraulics, and fluvial geomorphology and ensured the consistency and quality of these activities) issued OSW Technical Memorandum 09.01 (U.S. Geological Survey, 2008). The memorandum described the purpose and scope of the data verification effort and outlined the types of errors in the PFF and requirements for making and documenting error corrections.

Since then, many changes have been made to peak flows, gage heights, and qualification codes. The script that checks the peak-flow file for errors was modified in 2014 to facilitate more efficient review of the PFF through the elimination of some false positives and reduction in the dependence on repetitive reviews (Ryberg and Nielsen, 2014). Updated results were made available to all WSCs; checks are routinely rerun as part of the normal USGS technical reviews and when requested by a WSC.

\section{Purpose and Scope}

The purpose of this report is to provide a summary of the changes made to the PFF since the formal nationwide data verification project began in 2008. This document describes the checks and changes made to the PFF from November 19, 2008, through November 14, 2016. Coverage 


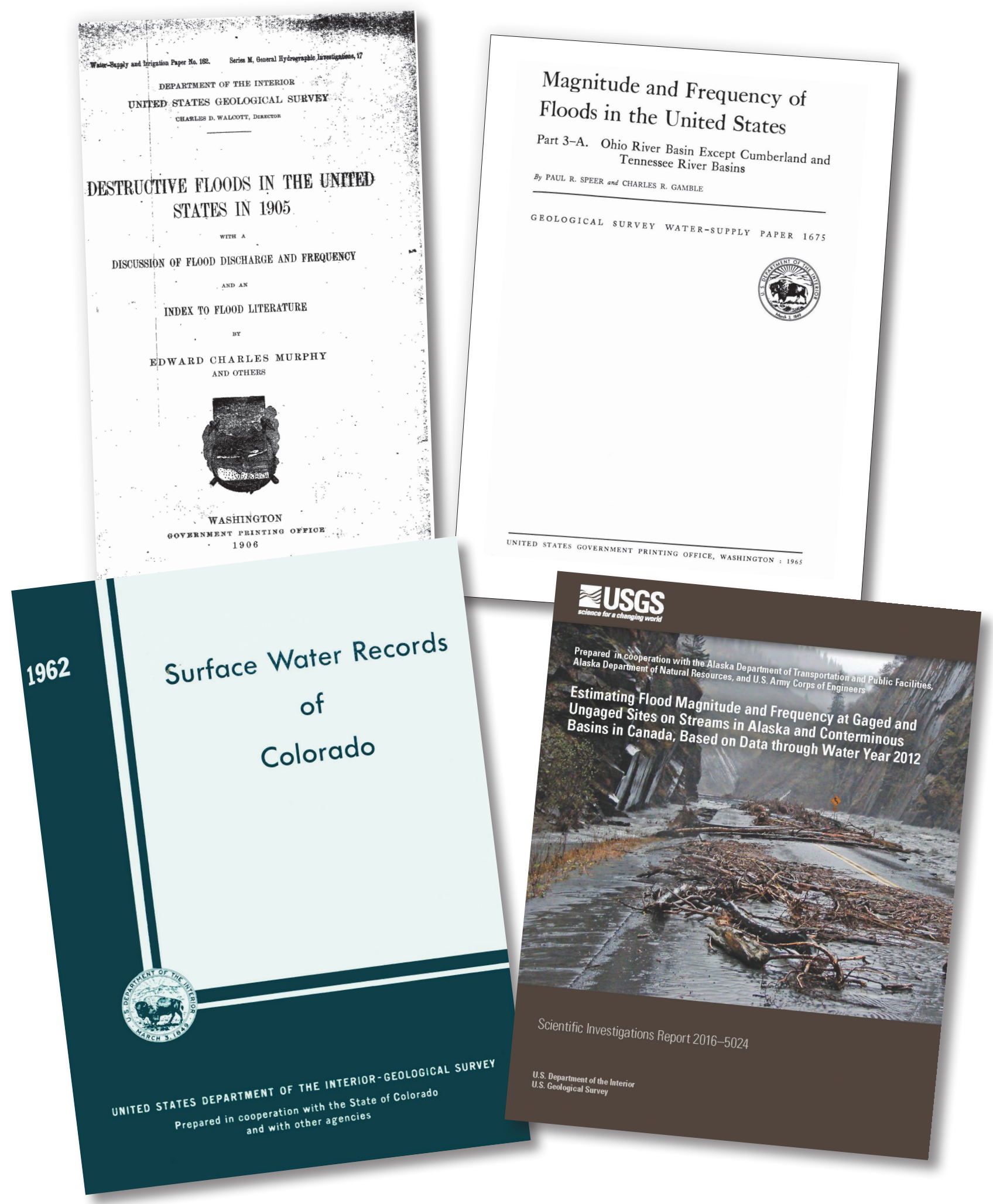

Figure 1. Title pages from U.S. Geological Survey reports highlighting the history, geographic diversity, and uses of the peak-flow file. Top left: 1906 U.S. Geological Survey Water-Supply Paper documenting 1905 floods (Murphy, 1906). Top right: cover of water-supply paper from 1965 that presented results of flood-frequency analysis and published flood data that had been collected at streamgages within the Ohio River Basin (with the exception of the Cumberland and Tennessee River Basins; Speer and Gamble, 1965). Bottom right: cover of annual water-data report for Colorado surface water in water year 1962 (U.S. Geological Survey, 1962). Bottom left: cover of report documenting a recent (2016) flood study in Alaska (Curran and others, 2016). 
includes peak-flow streamgages in all 50 States, Washington D.C., American Samoa, Guam, Micronesia, Northern Mariana Islands, Palau, Puerto Rico, and the U.S. Virgin Islands. General summaries of the number and type of changes and cartograms illustrating the locations of streamgages where data have been changed are provided. The accompanying USGS data release (Williams-Sether and others, 2017) provides snapshots of the PFF as it existed in 2008 and 2016. These data were used to generate cartograms and numerical summaries and provide the prechange and postchange data for users to make their own comparisons.

\section{Data Representing Peak-Flow File Changes}

The entire USGS PFF was retrieved on November 19, 2008, and on November 14, 2016. Limitations of the datasets include that there are no secondary peaks in the database and that all gage-height only records were removed (some entries have been made to the PFF for crest-stage gages or stage-only gages that have no peak-streamflow values); therefore, the numbers presented in the results reflect only those streamgages with at least one peak-flow value. A USGS data release (Williams-Sether and others, 2017) contains three files and their associated metadata files that provide a summary of the changes made to the USGS PFF since formal nationwide checking began in 2008. These data will allow users to reproduce the results presented here and complete their own investigations of changes. The files contained in the data release are described below.

Peak Flow File November 19, 2008.-This comma separated values (csv) file is a snapshot of the USGS PFF on November 19, 2008. The file lists station identification, water year, peak date, peak time, peak values, peak-streamflow qualification codes, gage-height values, gage-height qualification codes, and year of last peak for all streamgages for which peak flow has been recorded.

Peak Flow File November 14, 2016.-This csv file is a snapshot of the USGS PFF on November 14, 2016. The file lists, in the same order, the information contained in the PFF for November 19, 2008.

Percentage Differences Streamflow.-This csv file is a snapshot of percent difference in peak-flow values between November 19, 2008, and November 14, 2016. The file lists station identification, water year, original (2008) peak value, current (2016) peak value, and percent difference calculated per water year. The percent difference was calculated as the absolute value of ([current peak value-original peak value]/ [original peak value] $\times 100$ ).

The latitude and longitude describing the locations of the peak-flow streamgages were not checked as part of this process but were used for some of the results that follow. Latitude and longitude for a given streamgage may be obtained by visiting https://nwis.waterdata.usgs.gov/nwis/ peak?site_no=XXXXXXXX, where "XXXXXXXX" is the USGS station identification number, such as 05054000 (https://nwis.waterdata.usgs.gov/nwis/peak?site no $=05054000$ ). For the streamgages depicted here, decimal latitude and longitude were retrieved using the readNWISsite() function of the R package dataRetrieval (Hirsch and De Cicco, 2015).

It is important for readers to note that the most current and definitive source of peak-flow data is the PFF in NWIS, available at https://nwis.waterdata.usgs.gov/usa/nwis/peak (U.S. Geological Survey, 2017b). New peaks have been added since the November 14, 2016, snapshot and additional changes to past peaks may have been made.

\section{Types of Errors in the Peak-Flow File}

Webinars regarding the need to improve the PFF and the tools available for making these improvements were given to WSC personnel on December 5, 2008, and January 5, 2009. The nature and extent of documentation that would be needed to describe changes to the PFF were described. Three main categories of possible errors were discussed:

- data-entry errors,

- data-processing errors, and

- data-collection errors.

Data-entry errors include clerical and transcription errors, misplaced decimal points, and transposed digits. They are the most common and the easiest to find and correct. Changes for these types of errors did not require documentation unless the changes resulted in a need to revise published records (Novak, 1985). It was encouraged (but not required) that WSC personnel provide minimum explanatory notes in the comment field in PKEntry (not publicly available), such as "corrected to match ADR" (meaning that the correct PFF value was published in the annual-data report and the suspect PFF entry was changed to match it).

Data-processing errors include mistakes in record computations and are more time consuming to correct because they likely involve looking at paper records, many of which are stored offsite in Federal Records Archives and maintained by the Federal government. Example documentation of changes might indicate "datum incorrectly surveyed" or that the wrong stage-discharge relation was applied or a correction (shift) was applied in the wrong direction. The last two examples might be described in internal USGS communications as "rating 1 used instead of the applicable rating 2" or "wrong sign applied to shift of June 2, 1999." Documentation for these changes often involves adding a memo to the record identifying who reviewed what, how it was fixed, or why it was not, as described in OSW Technical Memorandum 92.10 (U.S. Geological Survey, 1992). In addition to documenting 
any changes, the memo suggested that WSC personnel other than the person making the correction should independently check the work that went into the new data computation.

Examples of data-collection errors include the following:

1. outliers or otherwise suspicious peaks for which the original records cannot be found;

2. errors in field work or uncertain interpretation; or

3. questionable or inappropriate application of field conditions for indirect measurements to apply the one-dimensional models previously used to estimate the peak; for example,

- the slope was too severe,

- the bed was too mobile, or

- the hydraulics were too complex (expanding sections, extreme velocities, large roughness values, surge, or waves).

Some of these data-collection errors may be difficult to resolve and may be candidates for future follow-up efforts. In some situations, WSC personnel used an internal option to verify a peak as questionable. This option verified that they had investigated a peak and determined it was questionable but could not identify or conclusively determine a new, more reliable peak flow, stage, date, or qualification code. Some questionable peaks could be investigated in the future by requesting archived records that documented the original peak determination or by completing additional field investigations. Documentation of changes caused by data-collection errors, or the inability to make changes to questionable data, might include internal memos describing difficult issues or complex reviews that led to changes, an entry in PKEntry that verifies data as questionable (but unresolvable at this time), and comments sufficient to permit informed followup.

From November 19, 2008, to November 14, 2016, many changes were made to records in the PFF. Most changes were made because of the peak-flow data verification effort; however, some changes may have resulted from independent review by individual WSC personnel in the normal completion of an at-site flood-frequency analysis or as a result of public comment or inquiry. Most of these changes were for one element, either peak flow, the gage height associated with the peak flow, the date associated with peak flow, or a qualification code; however, multiple elements may have been modified in some of the changed records. Changes of peak date values might have been motivated by any of these three categories of changes. In addition to changes made to entries for individual peak flows, some checks were done on the site information, including checking if the drainage area and hydrologic unit code fields were populated. Checks and potential changes to the annual peak-flow values, gage-height values, and qualification codes are described in the following sections.

\section{Checks Done on Peak-Flow Values}

The logic and the mathematics of the automated dataverification checks that were done are described in Ryberg (2008). The most relevant procedures are summarized below with a description of the test as well as an abbreviation of the test to link it back to Ryberg (2008) and the test reports from PFReports that the WSCs received where the abbreviations were used.

\section{Peak Greater Than or Equal to Daily Mean Value (PGTDV)}

A common reason for change is that many peak-flow values that did not meet or exceed the daily mean value (DV) for the date of the peak were detected. This check flagged several issues: (1) sometimes the magnitude of the peak was correct but the date was wrong, and, therefore, the comparison was against the wrong DV, so the error in the date was determined and corrected; (2) when paper records were converted to electronic records in the NWIS database in 1969, data-entry errors were made, sometimes including the addition or deletion of a 0 on the end of the peak value; and (3) DVs are rounded and, although USGS reporting standards indicated that maximum streamflows should be reported to the same number of significant digits as DVs (Novak, 1985, p. 81 and 86), oftentimes, the peak flows were not rounded, which sometimes made them less than the DV. This check applies only to those streamgages/peaks for which DVs exist; therefore, some data-entry errors may have been missed.

\section{Comparison to Annual Mean Values (AMV)}

A check for the absence of peaks was done for streamgages and years that had a complete DV record for a water year. A complete DV record usually is accompanied by the presence of an annual mean value in NWIS. Peaks should be entered in the PFF for all streamgages for which sufficient record exists to compute annual statistics with complete DV records. The test did not apply for streamgages with less than 5 years of record. In 2014, this check was changed to examine only the last 30 years of record.

\section{Check for Dependent Peaks (DP)}

Consecutive peak-flow values were checked to verify that they were from independent events rather than a single flood that spanned 2 water years (such as when a peak flow that was measured on September 30, 2010, was the highest peak flow for the 2010 water year and the peak flow that was measured on October 1, 2010, was the highest value for the 2011 water year). According to the Water Resources Division (WRD) Data Reports Preparation Guide (Novak, 1985), two peaks are considered independent only when a well-defined 
trough between them is equal to or less than 75 percent of the instantaneous discharge of the lower peak. Instantaneous values are not available in NWIS before October 1, 1950, and many streamgages, even if they were operational before 1950 , have a much shorter period of instantaneous data availability in NWIS. Therefore, DV data were used to approximate the trough; thus, the test may be insensitive for some streamgages, and the test applied only to those streamgages for which DVs existed, so some dependent peaks may not be identified by the checks. For peaks identified as dependent, WSCs were instructed to examine the instantaneous data and, if peaks still met the dependent criteria, remove the lower of the two peaks from the PFF and replace it with the next highest peak for that water year.

The WRD Data Reports Preparation Guide (Novak, 1985) states three criteria for determining independent peaks. The first criterion is described above. The second criterion is, "for small, highly responsive watersheds, only the highest peak discharge resulting from an obvious single storm event should be reported regardless of the trough configuration or magnitude between peaks" (Novak, 1985, p. 93). The third criterion is, "for periods of diurnal peaks caused by snowmelt, report only the highest peak during each distinct period of melting, if such periods can be identified, even though other peaks may meet the preceding criteria. Identification of each distinct period of melting is largely a matter of individual judgment, but the principle, as explained in paragraph 1 above, for instantaneous discharges can be applied to daily discharges as an identification guide" (Novak, 1985, p. 93). The second and third criteria require some subjective judgment as to what constitutes a "highly responsive watershed" or "distinct melting periods;" therefore, these criteria were not tested in the checks for dependent peaks.

\section{Linear Regression of Peak on Daily Mean Value (LRGPDV)}

A regression of peak flow on the DV was completed at each streamgage, and outliers were identified (outlier definition and examples of peaks identified are in Ryberg, 2008). Some of the outliers could be corrected by fixing the previous peaks that were not greater than or equal to the DV; for example, a peak mistyped as 100 rather than 1,000 will be identified as a peak that is less than the corresponding DV and as an outlier in the linear regression. Corrections made based on the regression, additions made based on missing peaks with associated annual mean values, and the addition of new peaks will change subsequent linear regression relations and change the outcome of future applications of the test, including possibly identifying previously unidentified outliers. Outliers were listed by streamgage and date; were indicated on plots of DVs against peaks, water year against semi-studentized residuals (the residuals from the regression relation divided by the square root of mean-squared error, further described in Ryberg, 2008), log predicted peak against semi-studentized residual; and were shown on hydrographs of DVs 10 days before and after the identified outlier(s). The test was completed only on streamgages with at least 10 annual peaks that have associated DVs. An example from PFReports that identified two potential outliers for the John Day River at McDonald Ferry, Oregon, USGS streamgage 14048000, is shown in figure 2. The peak flow on May 17, 1908, was recorded as 11,700 cubic feet per second $\left(\mathrm{ft}^{3} / \mathrm{s}\right.$; natural $\log$ of $\left.9.34 \mathrm{ft}^{3} / \mathrm{s}\right)$, whereas the daily mean value was $2,260 \mathrm{ft}^{3} / \mathrm{s}$ (natural log of $7.72 \mathrm{ft}^{3} / \mathrm{s}$ ) - a large discrepancy. Similarly, on January 2, 2006, peak flow was recorded as $144,000 \mathrm{ft}^{3} / \mathrm{s}$ (natural log of $11.9 \mathrm{ft}^{3} / \mathrm{s}$ ), whereas the daily mean value was $12,200 \mathrm{ft}^{3} / \mathrm{s}$ (natural $\log$ of $9.41 \mathrm{ft}^{3} / \mathrm{s}$ ) — an even larger discrepancy. There were no qualification codes for the peaks that would indicate abnormal conditions. Investigation determined that the date was incorrect for the 1908 peak and was therefore being compared to the wrong DV. The date was subsequently changed
Figure 2. Example of regression of peak streamflow on the daily mean values for the John Day River at McDonald Ferry, Oregon, U.S. Geological Survey streamgage 14048000. Two potential outliers are identified by the red Xs, and 'Model' identifies the regression line of peak streamflow and daily mean values.

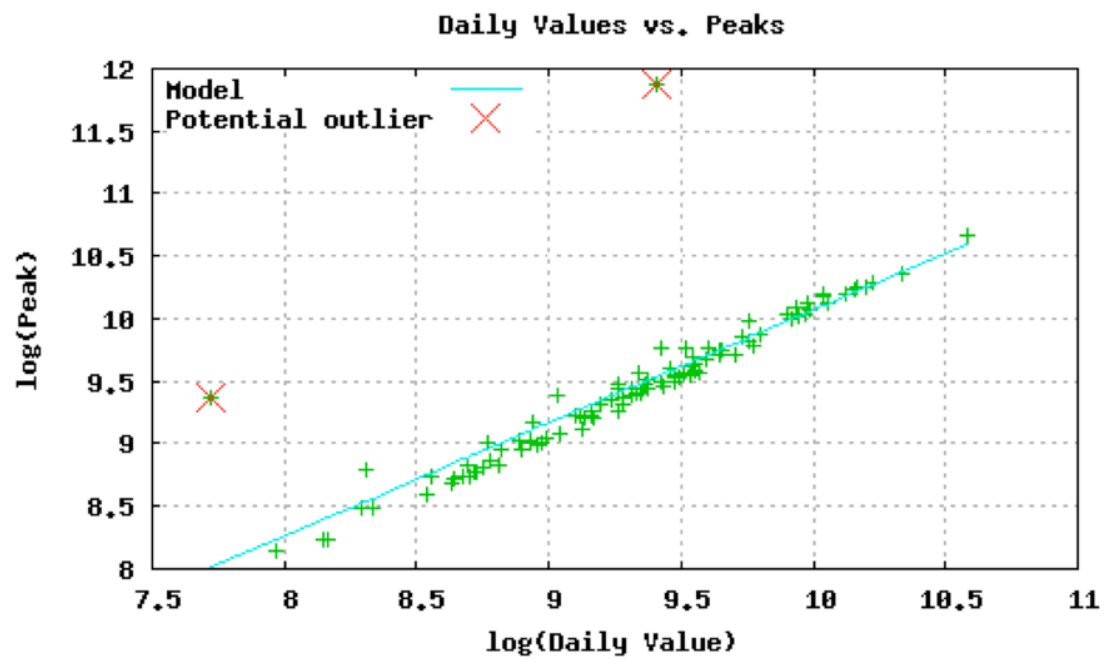


from May 17, 1908, to March 17, 1908. One can imagine that when paper records were entered into an electronic record a data-entry error was made, entering " 5 " for the month, instead of "3." The 2006 peak should have been entered as 14,400 but was entered as 144,000. Again, this was a data-entry error, and similar errors were common across the country.

In addition, reports were provided to WSCs that listed (1) all peaks with a streamflow value equal to zero (this is common in many western areas but uncommon in the more humid eastern United States, and WSCs in the eastern United States could use the report to investigate the validity of zero streamflow events), (2) those peaks verified as correct (the peak seems to be an outlier by some measures but there is a code or other justification for the value), and (3) those peaks verified as questionable (the peak is an outlier and unlikely, but there are no available records to justify a change).

\section{Checks Done on Gage-Height Values}

Although gage-height values are rarely used directly in flood-frequency analyses, they provide important historical information and key quality-assurance variables. Gage-height values were reviewed and, in some situations, corrected as part of the peak-flow data-verification project. In addition, gage-height data may have been changed for entirely different reasons; for example, if a new datum reference for the streamgage is developed, perhaps as a result of new topographic mapping. The comparison techniques used for this report cannot distinguish among the changes that resulted from such activities. Descriptions of the tests used to check gage height follow.

\section{Check for Existence of Gage Height (GH)}

Entries in PFF were checked for the existence of a gageheight value when the peak flow was greater than zero and the peaks had no qualification codes or qualification codes other than 1 or 2 (table 1; see "Peak-Flow File Qualification Codes" section). Generally, a gage height serves as the basis for a peak-flow determination and can help identify the stagestreamflow relation (rating curve) in use at the time of the peak; therefore, gage height should be in the database.

\section{Linear Regression of Gage Height on Peak Flow}

A regression test similar to that described for peak flows and DVs and documented in Ryberg (2008) was done using a regression of gage height on peak flow. The sensitivity of this test is diminished by changes in the gage datum, the stage-discharge rating, or regulation, and such changes are often apparent in plots of the regression residuals against date. Outliers were identified for streamgages with at least 10 peaks. For some outliers, a qualification code was listed that justified the outlier condition; for others, the lack of an explanatory code prompted the addition of a code, whereas some were data-entry errors in either the peak flow or the gage height.

\section{Peak-Flow File Qualification Codes}

The USGS uses qualification codes to provide additional information pertaining to published peak-flow values. The codes often convey the limitations of specific data that might affect the interpretation or treatment of that data in a floodfrequency analysis completed through manual or automated flood-frequency algorithms such as PeakFQ (Flynn and others, 2006). These codes are legacy implementations stemming from an era when computer storage was limited and costly and more complete data descriptions could not be accommodated regardless of their value; some codes had multiple uses depending on flood or site conditions and context. One or more codes may be assigned to annual peak-flow values, the gage height associated with specific peak-flow values, or the annual peak gage height associated with an observed peak flow that was not the peak flow of the year. One of the issues that complicates verifying code uses is varying code interpretations over time in and among WSCs. The OSW clarified and, in a few situations, redefined some of the codes in OSW Technical Memorandum 09.01 and required the WSCs to adopt and more uniformly use the new definitions (U.S. Geological Survey, 2008). These requirements resulted in a substantial number of changes to qualification codes in the PFF even when the peak-flow values were correct.

Qualification code definitions can be viewed in NWIS by visiting https://nwis.waterdata.usgs.gov/ nwis/peak? site_no $=$ XXXXXXXX\&format $=r d b$, where "XXXXXXXX" is the USGS station identification number, such as 05054000 (https://nwis.waterdata.usgs.gov/nwis/ peak?site_no $=05054000 \&$ format $=\mathrm{rdb}$ ).

Qualification code errors were divided into two categories:

1. data-entry errors (missing or unnecessary code entries), and

2. data-processing errors (inappropriate use of a code).

WSCs were given two rules for applying codes:

1. do not apply a code (or multiple codes) unless it is necessary to avoid misinterpretation of the data, and

2. document code assignments and their basis in the annual (internal) station analysis files.

As part of the PFF data verification process, or because of other WSC studies, numerous changes were made to peak-flow qualification codes and peak gage-height qualification codes, some of which could significantly affect floodfrequency computations. The following sections specifically describe the qualification codes, give guidelines for their 
usage, and provide additional information about how the codes affect flood-frequency computation.

\section{Peak-Flow Qualification Codes}

The qualification codes provide important information about the peaks and are used by flood-frequency programs to control processing of the peak discharges. Some codes may result in quantifiable computational effects; others may serve as generalized warnings that might prompt a user to gather more information. The peak-flow qualification codes defined in NWIS are shown in table 1. The peak-flow qualification codes and descriptions of how the USGS flood-frequency analysis program PeakFQ (Flynn and others, 2006) interprets the codes are shown in table 2.

The original definitions of the qualification codes were terse and, thus, subject to interpretation; therefore, the webinars describing the verification effort included a review of qualification codes (Larry Bohman, U.S. Geological Survey, oral and written commun., December 5, 2008, and January 5, 2009), and new definitions were distributed in appendix A of OSW Technical Memorandum 09.01 (U.S. Geological Survey, 2008). Combining the NWIS, PeakFQ, appendix A of OSW Technical Memorandum 09.01, and the webinar definitions creates the following text definitions of the peak-flow qualification codes.

Table 1. Peak-streamflow qualification codes used in the U.S. Geological Survey National Water Information System (U.S. Geological Survey, 2017b).

\begin{tabular}{|c|c|}
\hline $\begin{array}{l}\text { Peak-flow } \\
\text { qualification } \\
\text { code }\end{array}$ & Definition \\
\hline 1 & Discharge is a maximum daily average. \\
\hline 2 & Discharge is an estimate. \\
\hline 3 & Discharge affected by dam failure. \\
\hline 4 & $\begin{array}{l}\text { Discharge less than indicated value, which is mini- } \\
\text { mum recordable discharge at this site. }\end{array}$ \\
\hline 5 & $\begin{array}{l}\text { Discharge affected to unknown degree by regula- } \\
\text { tion or diversion. }\end{array}$ \\
\hline 6 & Discharge affected by regulation or diversion. \\
\hline 7 & Discharge is an historic peak. \\
\hline 8 & Discharge actually greater than indicated value. \\
\hline 9 & $\begin{array}{l}\text { Discharge due to snowmelt, hurricane, ice-jam or } \\
\text { debris dam breakup. }\end{array}$ \\
\hline A & Year of occurrence is unknown or not exact. \\
\hline B & $\begin{array}{l}\text { Month or day of occurrence is unknown or not } \\
\text { exact. }\end{array}$ \\
\hline $\mathrm{C}$ & $\begin{array}{l}\text { All or part of the record affected by urbanization, } \\
\text { mining, agricultural changes, channelization, } \\
\text { or other. }\end{array}$ \\
\hline $\mathrm{D}$ & Base discharge changed during this year. \\
\hline $\mathrm{E}$ & Only annual maximum peak available for this year. \\
\hline
\end{tabular}

Code 1.-Code 1 indicates that the discharge is a maximum daily average. This code should be used only if the instantaneous value cannot be estimated and is believed to be substantially larger than the DV. A code 1 implies that the peak is likely biased low. Code 1 should not be used if the DV is approximately equal to the instantaneous peak, like for large rivers or basins with little topographic relief. If possible, estimate instantaneous peak discharge, qualified by code 2 , if necessary, instead of using a DV. Peaks qualified with a code 1 are used by the USGS flood-frequency analysis program PeakFQ.

Code 2.-Code 2 indicates that discharge is an estimate. This code is used to characterize peak-flow values that are generally less accurate or less reliable than other values in the database. The peak still should be defensible and reasonable in light of available field evidence and current comprehension of flow hydraulics and processes. Examples of situations for which code 2 is appropriate include the following:

- the gage recorder malfunctioned or was destroyed during a flood and the peak gage height was determined afterward from a high-water mark,

- indirect measurement was made a distance from the streamgage or was rated less than fair,

- the rating curve had larger than recommended extensions,

- a routing/modeling technique did not involve measured stage-discharge relations at the streamgage, and

- stage-discharge relations were affected by ice.

Peaks qualified with code 2 are used by PeakFQ. Occasionally, unusual circumstances relating to the origin of the peak (such as failure of ice jams or a debris dam) require an estimate to be used. In these circumstances, the peak may also be accompanied by a code 9 .

Code 3.-Code 3 indicates that discharge was affected by dam failure - discharge affected by unplanned and uncontrolled release of stored water with concurrent destruction of the dam or other storage barrier. Code 3 should not be used to indicate glacial outbursts or debris dam failure (code 9), emergency reservoir releases (code 5 or 6 ), or partially failed dams where flow is computed assuming that the dam was intact at the peak and failed later. PeakFQ excludes code 3 peaks because they are unique events that do not represent future flood risk.

Code 4. - Code 4 indicates that discharge is less than the indicated value, which is the minimum recordable discharge at this site. This code typically is used for crest-stage gages set too high to record the peak during a low-runoff year. This code should only be used if it is likely that there was nonzero flow at some time during the year. If the stream was dry all year, a discharge of zero should be reported without qualification. Peaks qualified with this code are interpreted as defining the lower limit of the flood-frequency curve at this streamgage. In PeakFQ under Bulletin 17B methods (Interagency Advisory 
Table 2. Peak-streamflow qualification codes used by the U.S. Geological Survey program PeakF0. Modified from Flynn and others, 2006.

[NWIS, National Water Information System; PeakFQ, a program that performs statistical flood-frequency analysis of annual maximum peak flow]

\begin{tabular}{|c|c|c|}
\hline $\begin{array}{l}\text { Peak-flow } \\
\text { qualification } \\
\text { code in NWIS }\end{array}$ & PeakF0 interpretation & PeakF0 action \\
\hline 3 & Dam failure, nonrecurrent flow anomaly & Peak always excluded. \\
\hline 8 & Discharge greater than stated value & $\begin{array}{l}\text { Peak always excluded using Bulletin 17B methods or default } \\
\text { perception threshold and flow interval using expected mo- } \\
\text { ments algorithm (Veilleux and others, 2013). }\end{array}$ \\
\hline 4 & Discharge less than stated value & $\begin{array}{l}\text { Conditional-probability adjustment using Bulletin 17B meth- } \\
\text { ods or default perception threshold and flow interval using } \\
\text { expected moments algorithm (Veilleux and others, 2013). }\end{array}$ \\
\hline 6 or $\mathrm{C}$ & $\begin{array}{l}\text { Known effect of regulation, urbanization, or other } \\
\text { watershed change }\end{array}$ & $\begin{array}{l}\text { Peak excluded by default. Can be included by specifying "yes" } \\
\text { in the "Urban/Reg Peaks" field of the PeakFQ station specifi- } \\
\text { cations. }\end{array}$ \\
\hline $\begin{array}{l}1,2,5,9, \mathrm{~A} \\
\mathrm{~B}, \text { or } \mathrm{E}\end{array}$ & Codes are not considered by PeakFQ & Peak always included. \\
\hline
\end{tabular}

Committee on Water Data, 1982), all peaks less than or equal to the highest peak flagged with code 4 are treated as if they were flagged with a code 4 , which has the effect of setting them equal to zero. By default, these peaks are not included in Bulletin 17B PeakFQ frequency analysis, but the user may include these peaks by specifying a value lower than the lowest peak qualified with a code 4 value for the streamgage base discharge. Using the Expected Moments Algorithm (EMA) option in PeakFQ, code 4 peaks are used with default perception threshold and flow intervals that can be modified by the user (Andrea Veilleux, U.S. Geological Survey, written commun., 2017).

Codes 5 and 6.-Codes 5 and 6 indicate regulation; that is, human-made, planned (whether automated or manual) control of flow, including retention ponds, siphons, and reservoirs. The difference between code 5 (discharge affected to unknown degree by regulation or diversion) and code 6 (discharge affected by regulation or diversion) is admittedly fuzzy and subject to differing interpretations. The difference is mainly one of certainty that there is a regulation effect on the peak discharge. The use of code 5 or 6 should be consistent with regulation statements in past USGS annual water-data reports. These codes alert users that flows are not natural. These codes are not intended for natural storage conditions, such as beaver dams, lakes, or swamps. A major difference between these two codes is that PeakFQ uses peaks qualified with code 5 but excludes code 6 peaks unless otherwise specified by the user.
Regulation of one peak discharge does not necessarily imply regulation of succeeding peaks. Substantial regulation or diversion should be verified independently for each peak; however, once a stream is regulated or diverted sufficiently to affect the peak flow, peaks generally continue to be affected. Rarely, if a source of regulation has been removed or ceases to be effective, the coding could be discontinued, or a code 6 could be replaced with a code 5 if residual regulation from unidentified sources remains. PFReports checks for the consistent use of codes 5 and 6 ; that is, once 5 or 6 is applied, PFReports checks for code 5 or 6 in the subsequent years. There may be false positives in PFReports results where it is entirely appropriate to not qualify a peak with code 5 or 6 , even though past peaks were so qualified.

Code 5.-Code 5 indicates discharge affected to an unknown degree by regulation or diversion and should be used when the exact magnitude of a planned regulation or diversion is unknown and probably insubstantial (less than 10 percent of the peak discharge). The effect may be either to decrease or to increase the regulated peak. Minor overflows and emergency releases that sometimes are thought of as dam failures should be qualified with code 5 if the degree of effect is unknown but probably not substantial and if such operations have happened repeatedly in the past or are likely to recur in the future. At some streamgages, natural storage such as beaver dams, lakes, or swamps can affect some peaks. Code 5 is not intended to be applied in such situations. PeakFQ frequency analysis includes peaks qualified with a code 5 . 
Code 6.-Code 6 indicates discharge affected by regulation or diversion and should be used for storage effects caused by planned structures or operations in situations where at least 10 percent of the basin is controlled by regulation or when usable storage in the basin exceeds about 103 acre-feet per square mile (Benson, 1962, p. 7-8). The structural or operational effect may be either to decrease or to increase the regulated peak. It should be noted that regulation of one peak discharge does not necessarily imply regulation of succeeding peaks, and discontinuing code 6 or using it periodically may be appropriate. For example, the peaks of medium floods may be affected greatly by some smaller reservoirs, but a very large flood may involve a volume of water that fills reservoir storage without affecting the magnitude of the peak; thus, substantial regulation or diversion should be verified independently for each peak. Such verification might be done by comparing upstream and downstream hydrographs or examining the stability of reservoir contents during a flood (inflow equals outflow).

Minor overflows and emergency releases that sometimes are thought of as dam failures should be qualified with code 6 if the effect is substantial and if such operations have happened repeatedly in the past or are likely to recur in the future. At some streamgages, natural storage such as beaver dams, lakes, or swamps can affect some peaks. Code 6 is not intended to be applied in such circumstances. Code 6 serves as a criterion for excluding regulated peaks from a homogeneous statistical sample of natural-flow peaks. By default, PeakFQ excludes peaks qualified with code 6 from the frequency analysis; the user may include these peaks by indicating "yes" for urbanized/regulated peaks.

Code 7.-Code 7 indicates that the peak is a historical peak; however, a better term is a nonsystematic peak. This has been subject to misinterpretation across the Nation. Many peaks of a historically unprecedented magnitude have been incorrectly qualified with this code. Code 7 is for peaks outside the systematic gaging record; that is, peaks determined before or after continuous data collection at a streamgage or during extended breaks (for example, there may be a gap in the record of a streamgage because of a lack of funding; however, there was a large flood during that gap and the peak was determined and recorded in the database; that is, a nonsystematic peak). These types of peaks are qualified because they are biased toward large floods; generally, they would not have been recorded except for the fact that there was a flood of large magnitude. Some of these peaks may have been opportunistic peaks; that is, other work was being done in the area, so the peak was documented because of convenience and not necessarily because it was a large peak. The PFF does not make a distinction between opportunistic peaks and the nonsystematic peaks that are biased toward large events, such as quantification of a nonsystematic peak based on a search of historical newspaper records for large floods. Peaks coded with a 7 are excluded from PeakFQ analyses using Bulletin 17B methods, unless the user specifies a Bulletin 17B (Interagency Advisory Committee on Water Data, 1982) historical record adjustment.
Using the EMA method in PeakFQ, the peak is included by default with a perception threshold and flow interval that can be modified by the user (Andrea Veilleux, U.S. Geological Survey, written commun., 2017).

Code 8.-Code 8 indicates that the discharge was actually greater than the indicated value. This code should be used only if the actual discharge cannot be estimated but is much larger than the peak-flow value recorded (for example, an overtopped streamgage for which high-water marks were not available). If there is any way to estimate the discharge, a code 2 should be used. Peaks qualified with code 8 are excluded from frequency analyses using PeakFQ Bulletin 17B methods because they may grossly understate the actual peak flow. Using the EMA method in PeakFQ, the peak is included with a default perception threshold and flow interval that can be modified by the user (Andrea Veilleux, U.S. Geological Survey, written commun., 2017).

Code 9.-Code 9 indicates that discharge was caused by hydrometeorological processes different from the predominant flood-generating mechanism for the specific streamgage but which are still common enough to represent overall future flood risk at this streamgage. The definition of different or unusual mechanisms varies from region to region and can include snowmelt, hurricanes, ice jams, or debris dam breakup. Where code 9 is used to a substantial degree, particularly when it is used to create subsamples of flood peak data, the WSC should explain in flood-frequency regionalization reports the process that it used to assign code 9 to individual peaks. At some streamgages, beaver dams, lakes, or swamps may affect all peaks, so code 9 is not used. PeakFQ uses code 9 peaks.

Codes $A$ and B. - Codes A and B indicate uncertainty about the date of the peak. Code A indicates that the year is unknown or not exact. Code B indicates that the month or day is unknown or not exact. If a month is not reported, the year reported should be the water year the peak happened in. The peak flow is used in frequency computations, not the date; therefore, PeakFQ uses peaks qualified with codes A and B, although the uncertainty evidenced by the unknown date may necessitate another code indicating uncertainty about the peak.

Code C.-Code C indicates that the peak is affected by urbanization, mining, agricultural changes, wildfire deforestation (land-cover changes), or channelization. Once applied, this code should continue to be applied until land use and drainage characteristics of the basin revert to natural conditions. PeakFQ excludes peaks with a code C; however, the user may change this when needed, such as when doing an urban flood-frequency study.

Code D. - Code D indicates that base discharge changed during the year. The "base" is a threshold above which peaks are determined (the annual peak and secondary or partial peaks). The best base level is not known at the outset; it may change and affect whether or not the previous peaks (annual and partial) are incomplete or some may need to be removed. If internal adjustments of past records are made, this code is not needed. PeakFQ uses code D peaks. 
Code E. - Code E indicates that only the annual maximum peak exceeded the flood base during that water year and, therefore, indicates years in which there are no other secondary or partial peaks above the flood base. This code should not be used to inform the user that the type of streamgage is a partial-record crest-stage gage. PeakFQ uses code E peaks. The determination of the flood base is beyond the scope of this report; however, readers may find additional details in Novak (1985, p. 91-93).

\section{Checks of the Peak-Streamflow Qualification Codes}

Checks were done for situations in which consistency or appropriateness of codes could be programmatically defined. The checks are summarized below with a description of the test as well as an abbreviation of the test to link it back to Ryberg (2008) and the reports from PFReports that the WSCs received.

\section{Check for Regulation Code Dropped after Initial Use (DropREG)}

Peaks were checked for the consistent use of codes 5 and 6 , including inadvertent omission or change of codes for regulation and diversion. After a peak code of 5 is first used, any subsequent peak that does not have a code of 5 or 6 is flagged. Once a peak code of 6 is used, any subsequent peak that does not have a code of 6 is flagged. After a streamgage is qualified with a code 5 or 6 , the test flags any subsequent peaks that omit the regulation or diversion code, even though it is possible that regulation may end or decrease in effect. There may be false positives in PFReports results where it is entirely appropriate not to qualify a peak with code 5 or 6 , even though past peaks were so qualified.

\section{Check for Missing Code 7 (Need7)}

Peaks were checked for potentially missing historical (nonsystematic) peak code 7. Peaks may be nonsystematic if they happen before systematic streamgaging begins, after it ends, or during a break in systematic gaging, unless the peak was observed and recorded in anticipation of near-term initiation of streamgaging or its resumption. This test was done on streamgages with at least five peak-flow values to avoid recommending code 7 for new streamgages.

\section{Check for Incorrect Usage of Code 7 (Not7)}

Peaks also were checked for incorrect usage of historical (nonsystematic) peak code 7. Peaks qualified with code 7 but that occurred at the beginning of, during, or at the end of what seems to be a systematic period of data collection were listed as peaks that might incorrectly be qualified with code 7 , and WSCs were instructed to investigate the appropriateness of the code.

\section{Check for Qualification of Inexact Dates (AB)}

Peaks were checked for omitted or inconsistent use of A or B qualification codes. The reports listed peaks that lack code A or B but have an invalid or missing month or day (examples include peak dates of 1978, 1978-04, 1978-04-00, or 1978-00-00), and peaks that have code A but have a valid month and day. Listed peaks were reviewed against original records by WSCs. Peaks with code A and a valid date most likely should be recoded with code B or the month and day should be removed. Peaks with a year but no month or day should be reviewed to determine if a code A or B is appropriate.

\section{Check for Omission of Code C (DropC)}

Peaks were checked for inadvertent omission of a code C, which identifies unusual land use or channel characteristics. Once a streamgage is affected by these conditions, the conditions usually remain indefinitely.

\section{Information Reports}

In addition to the checks described above, information reports documenting the use of the code were provided for peaks with codes 2 (and no gage height), 3, 4, 8, 9, A, B, $\mathrm{D}$, and $\mathrm{E}$. Using their institutional knowledge, WSCs could make sure known events, such as dam failures (code 3), were documented.

\section{Peak Gage-Height Qualification Codes}

In addition to the peak-flow qualification codes, there are gage-height qualification codes. These codes are less prominent because gage height is not used in flood-frequency computations; however, they are important indicators of conditions associated with the peaks. In NWIS, the peak gageheight qualification codes are defined as shown in table 3. These qualification codes were not directly checked as part of the checking process; however, investigation of entries in the PFF may have prompted changes to the gage-height qualification codes.

Table 3. Gage-height qualification codes used in the U.S. Geological Survey National Water Information System (U.S. Geological Survey, 2017b).

\begin{tabular}{cl}
$\begin{array}{c}\text { Gage-height } \\
\text { qualification } \\
\text { code }\end{array}$ & \multicolumn{1}{c}{ Definition } \\
\hline 1 & Gage height affected by backwater. \\
2 & Gage height not the maximum for the year. \\
3 & Gage height at different site and (or) datum. \\
4 & Gage height below minimum recordable elevation. \\
5 & Gage height is an estimate. \\
6 & Gage datum changed during this year. \\
\hline
\end{tabular}




\section{Limitations of Peak-Flow File Checks}

All checks were done on annual peaks only (secondary or partial peaks were not included). Some of the tests do not check every peak; for example, regression was done only when there were at least 10 nonzero peaks with associated DVs or gage heights. Checks that used DVs, such as making sure the peak flow was greater than or equal to the DV, were effective in finding data-entry errors in the peak value or date but would have missed such errors for peaks for which no DVs were available.

The Florida and North Dakota WSCs were early users of the results and helped refine the script that does the checking; therefore, not all changes made in Florida or North Dakota as part of this effort are represented in these results because some changes were made before the November 2008 snapshot of the PFF (U.S. Geological Survey, 2017b).

The automated process used is subject to false positives (identification of an outlier when the hydrologic conditions were unique and correctly recorded) and false negatives (not finding problems that actually do exist in the database), and these error rates are unquantified. An example of a false positive is shown in figure 3 , which presents a linear regression of the logarithm of peak flow on the logarithm of the daily mean value at the Red River of the North, Fargo, North Dakota (U.S. Geological Survey streamgage 05054000). Three outliers are indicated. The outlier in the lower left-hand corner indicates a peak on July 4, 1977. The peak value was $878 \mathrm{ft}^{3} / \mathrm{s}$; however, the daily mean value was $299 \mathrm{ft}^{3} / \mathrm{s}$. This is a large discrepancy, so weather records for the day were investigated. This peak happened during a period of very low streamflow and seems to have been caused by sudden urban runoff from a summer thunderstorm (Gregg Wiche, U.S. Geological Survey, oral commun., 2008). The peak was verified as correct. Some refinements were made to the tests in 2014 to decrease the false positive rate by eliminating peaks with particular codes from some of the checks and filtering out peaks already verified as correct for some of the checks (Ryberg and Nielsen, 2014).

\section{Comparison Methods}

The 2008 and 2016 PFF datasets were imported into the statistical software R (R Core Team, 2016), and values were compared in the two files using the code provided in appendix 2. Users of the PFF may visually inspect the files presented in the data release (Williams-Sether and others, 2017) for differences or import them into Access, R, or other software programs, and compare fields of records with matching station identification numbers and water years. The changes to the PFF are summarized in the following sections.

\section{Results of 2008 to 2016 Comparison}

The following numerical summaries and cartograms provide a broad overview of the extent of changes to the PFF. The list below highlights the number of changes and the percent of peak changes. All percent values are in relation to the number of peaks in 2008.

- Number of peaks in 2008 retrieval=659,332.

- Number of peaks in 2016 retrieval $=731,965$.
Figure 3. Example of regression of peak streamflow on the daily mean values for the Red River of the North, Fargo, North Dakota, U.S. Geological Survey streamgage 05054000 . Three potential outliers are identified by the red Xs, and 'Model' identifies the regression line of peak streamflow and daily mean values. The red $X$ in the lower left-hand corner was investigated and determined to be a correct value.

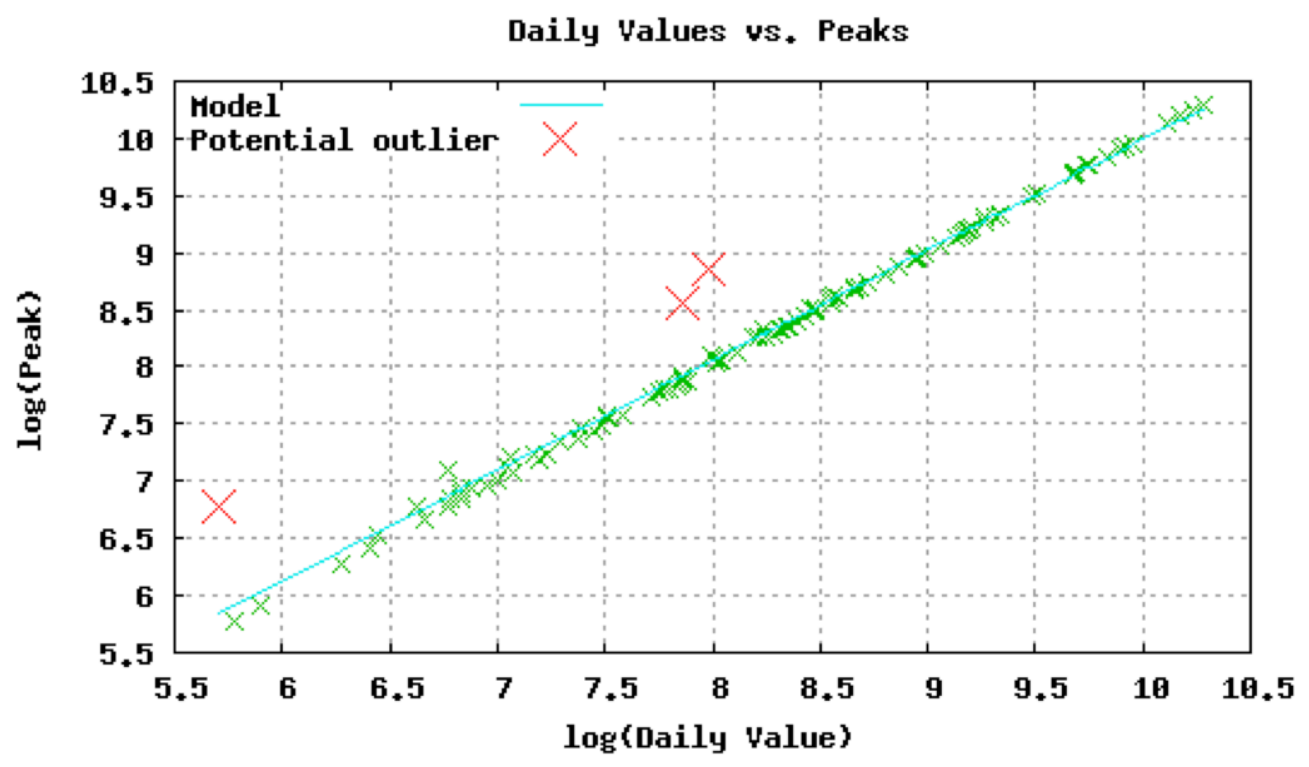


- Number of changed peak-flow values $=5,179$ (0.79 percent).

- Changes resulting in smaller peak-flow values in $2016=2,638$ ( 0.40 percent $)$.

- Changes resulting in larger peak-flow values in $2016=2,541$ ( 0.39 percent).

- Number of changed peak-flow qualification codes $=36,506$ (5.54 percent).

- Number of changed peak-flow dates $=1,938$ (0.29 percent).

- Number of changed gage heights $=18,599$ (2.82 percent).

- Number of changed gage-height qualification codes $=20,683$ (3.14 percent).

More detailed information about changes is provided in the following sections, including cartograms of changes at streamgages in the 50 States, Puerto Rico, and the U.S. Virgin Islands. Streamgages in American Samoa, Guam, and the Northern Mariana Islands are not included on the cartograms; however, any PFF changes at those streamgages are included in the counts. The cartograms may raise some questions as to why some States or regions have more or fewer changes than others. Users of the PFF should direct questions to the USGS WSC maintaining the streamgages of interest. Electronic inquiries may be made through NWIS by visiting https:// nwis.waterdata.usgs.gov/nwis/peak?site_no $=$ XXXXXXXX, where "XXXXXXXX" is the USGS station identification number, such as 05054000 (https://nwis.waterdata.usgs.gov/ nwis/peak?site no $=05054000$ ) and clicking on the link in the lower left-hand corner of the page that says "Questions about sites/data?"

\section{Changes to the Peak-Flow Value, Peak Date, or Peak-Flow Qualification Codes}

The field of most concern for flood-frequency analyses is the peak-flow value. Errors included transposed numbers, one or more zeroes appended to the end of a number, or a dropped zero at the end of a number; however, some changes had no obvious transposition or order of magnitude problem error, such as a streamflow value changed from $38 \mathrm{ft}^{3} / \mathrm{s}$ to $741 \mathrm{ft}^{3} / \mathrm{s}$. Numeric and geographic summaries pertaining to those peaks that were greater than 0 in 2008 and had a different value in 2016 are shown in figures $4-11$. When the number of changes represented in the cartogram is 30 or less, tables 4-7 provide details about the changes made. Where more than 30 changes were made, readers may consult the data release (WilliamsSether and others, 2017). A timeline of changes indicating the count of changes per water year is shown in figure 12. In figure 12, and subsequent similar plots, there is a substantial drop in the number of changes in the final bar (2008). One possible reason for this drop is that many of the peaks for water year 2008 may not have been entered into the database as of November 19, 2008.

Changes to the peak-streamflow qualification codes affect how the peaks are interpreted, including the interpretation of the peaks in PeakFQ. Graphic and numeric summaries of the changes to the peak-streamflow qualification codes are provided in figures 13-26. Again, when 30 or fewer changes are shown on a cartogram, the changes are provided in a table (tables 8-10). The peak-streamflow qualification code most frequently added was code B, which indicates that the month or day is unknown or not exact. Many peaks had unknown or inexact dates, such as 1902-00-00, but did not have the accompanying qualifier, and the check process substantially increased the usage of this code. A timeline with the count of peak-flow qualification code changes per water year is provided in figure 27.

Changes to the date of a peak may be of interest to those studying changes in timing of peak flow. A visual summary of the extent of these changes to peak date and changes to peak date and qualification code is provided in figure 28. A timeline with counts of changes to peak flow date per water year is provided in figure 29. Finally, some streamgages have changes to the peak-flow value, peak date, and peak-streamflow qualification code; these streamgages are shown in figure 30.

\section{Changes to the Gage Height or Gage-Height Qualification Codes}

Because gage height is commonly the basis for determining streamflow, PFF entries were checked for a gage-height value in two situations: (1) the peak flow was greater than zero and did not have any peak-streamflow qualification codes and (2) the peak was greater than zero and had any peak-streamflow qualification codes other than 1 or 2 . Code 1 indicates that streamflow is a maximum daily average, and code 2 indicates that streamflow is an estimate. Both codes 1 and 2 indicate that some method other than gage height may have been used to determine the peak flow; therefore, a missing gage height is acceptable. Many gage heights were added to the PFF (fig. 31), perhaps because flood-frequency studies that prompted past verification efforts focused on streamflow and did not need gage height. Gage-height qualification codes were not directly checked as part of the automated checking process; however, sometimes adding a code 1 or 2 explained why the gage height was missing. Other times, review of the PFF entry prompted changes to the gage-height qualification code. The changes to gage heights and gage-height qualification codes are summarized in figures $31-40$. 

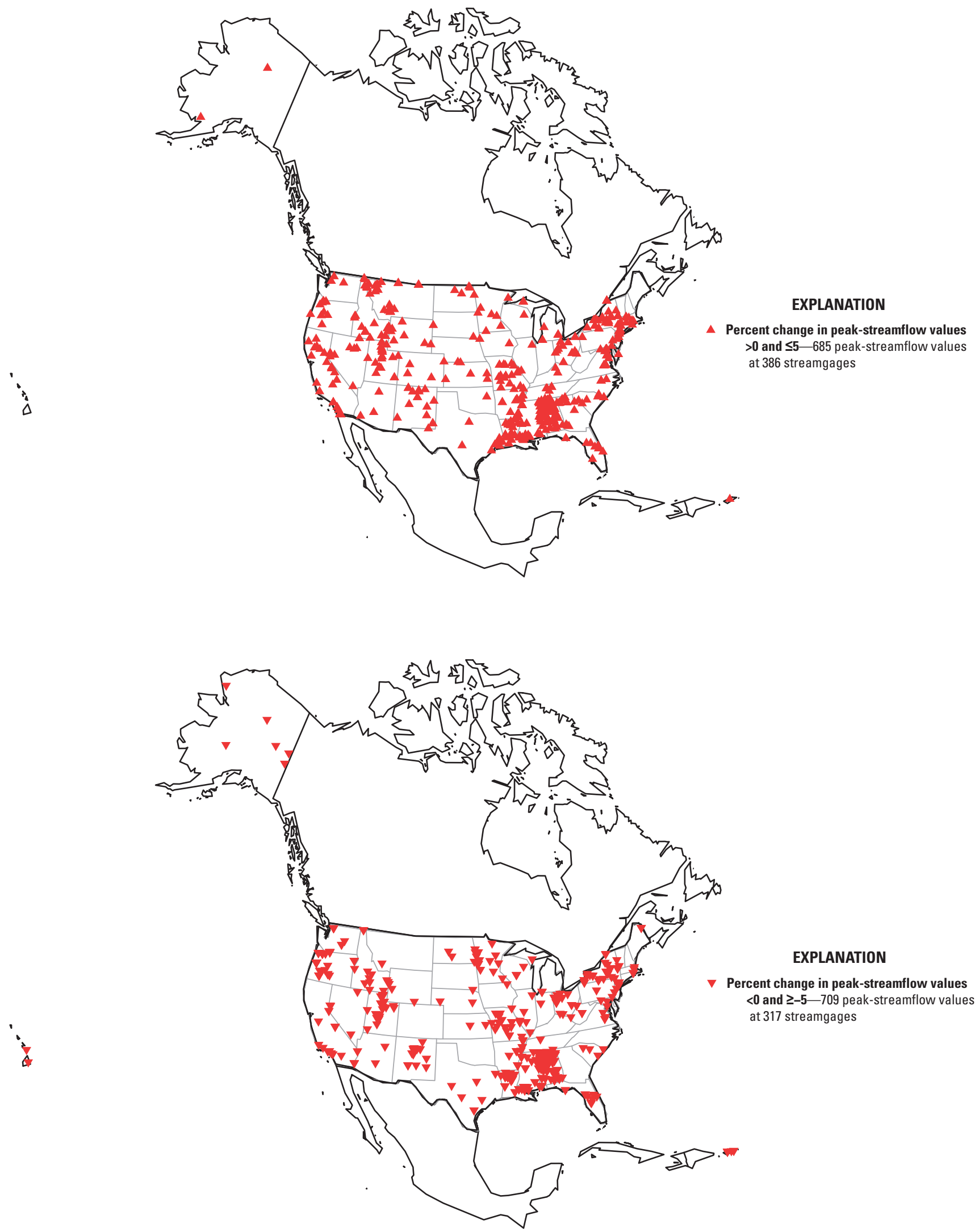

Figure 4. Cartograms of streamgages with absolute value of change in peak streamflow greater than 0 and less than or equal to 5 percent. Top cartogram shows streamgages with increases and bottom cartogram shows streamgages with decreases. 
$\Delta$
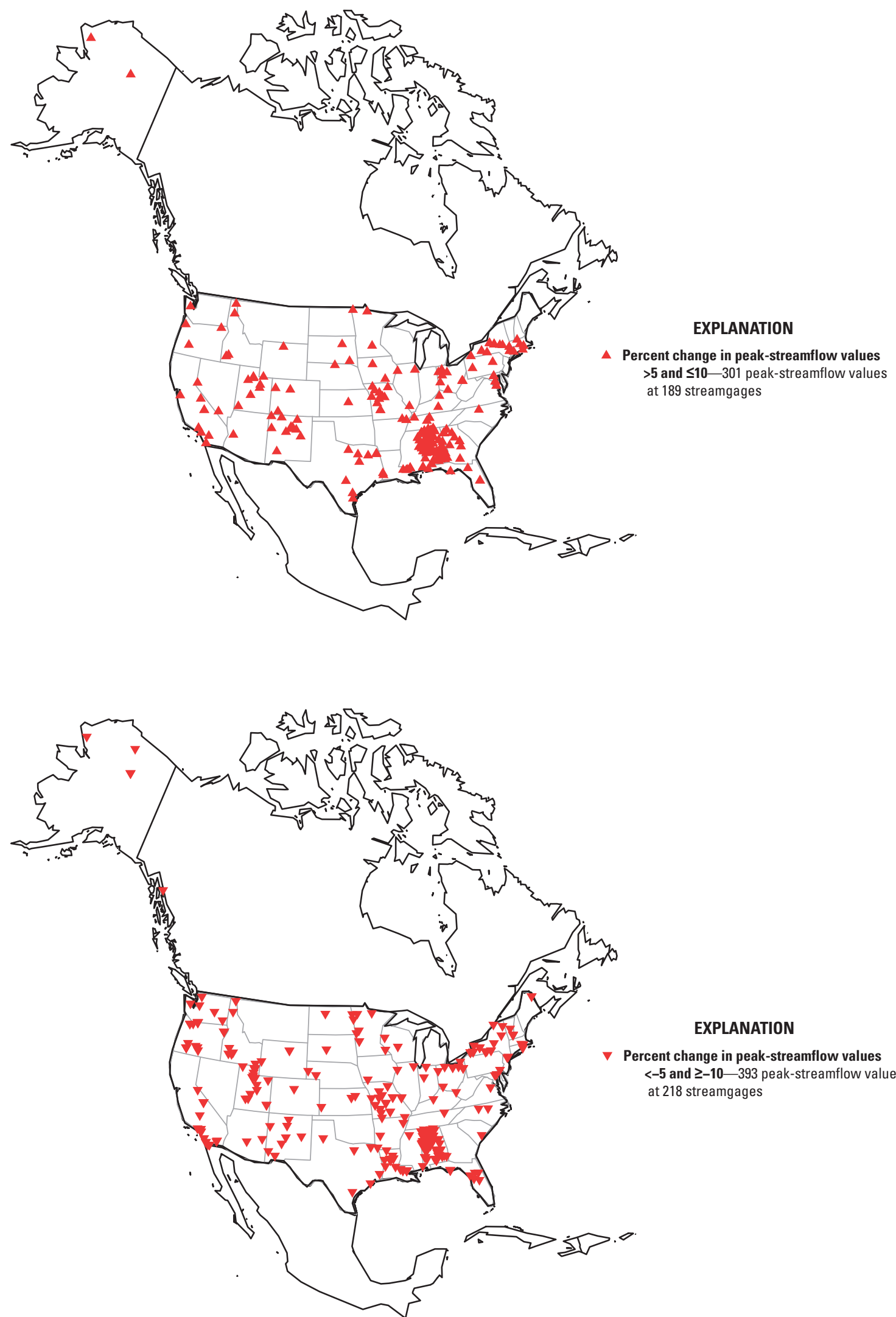

EXPLANATION

Percent change in peak-streamflow values $<-5$ and $\geq-10-393$ peak-streamflow values at 218 streamgages

i

Figure 5. Cartograms of streamgages with absolute value of change in peak streamflow greater than 5 percent and less than or equal to 10 percent. Top cartogram shows streamgages with increases and bottom cartogram shows streamgages with decreases. 
is
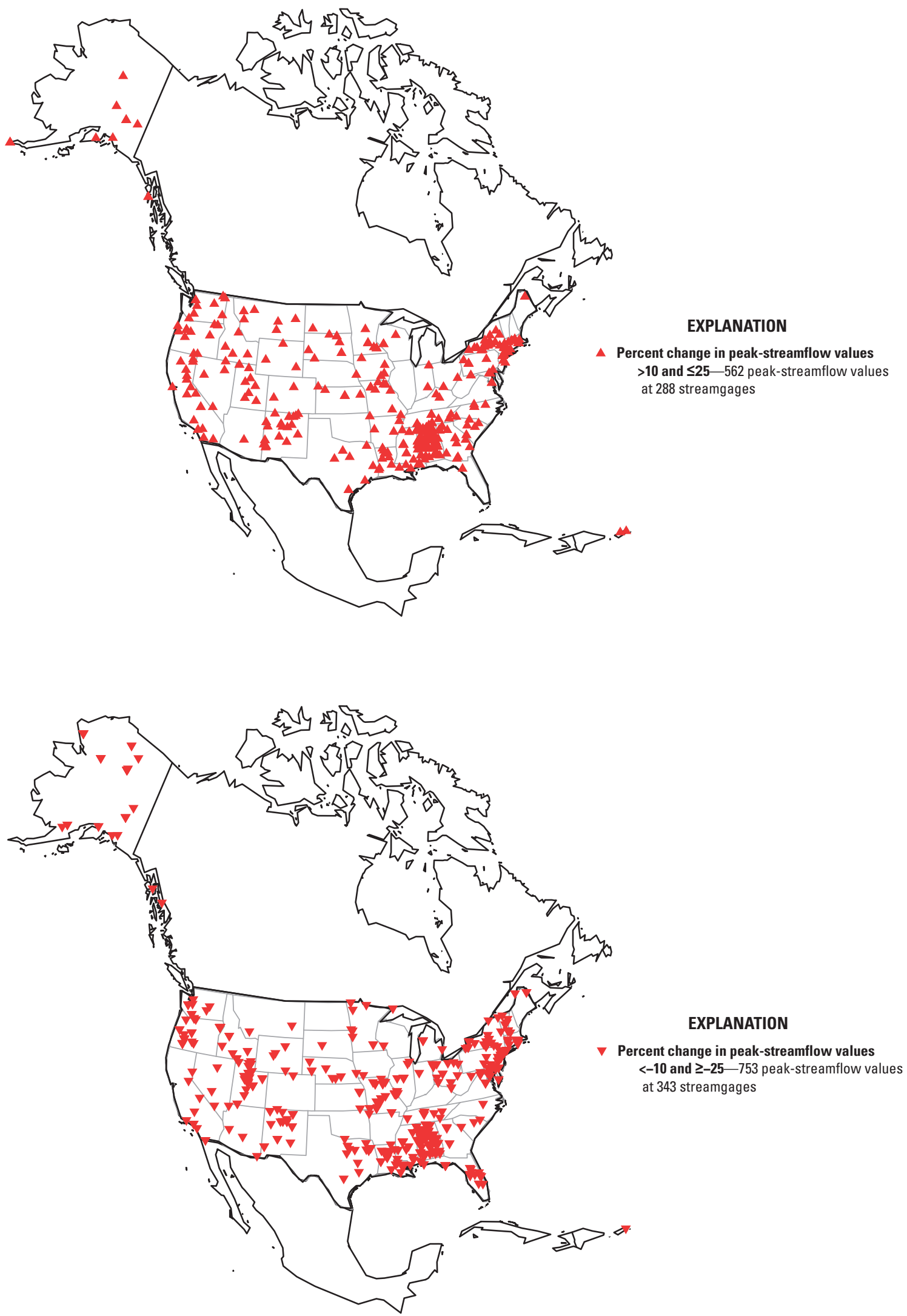

Figure 6. Cartograms of streamgages with absolute value of change in peak streamflow greater than 10 percent and less than or equal to 25 percent. Top cartogram shows streamgages with increases and bottom cartogram shows streamgages with decreases. 

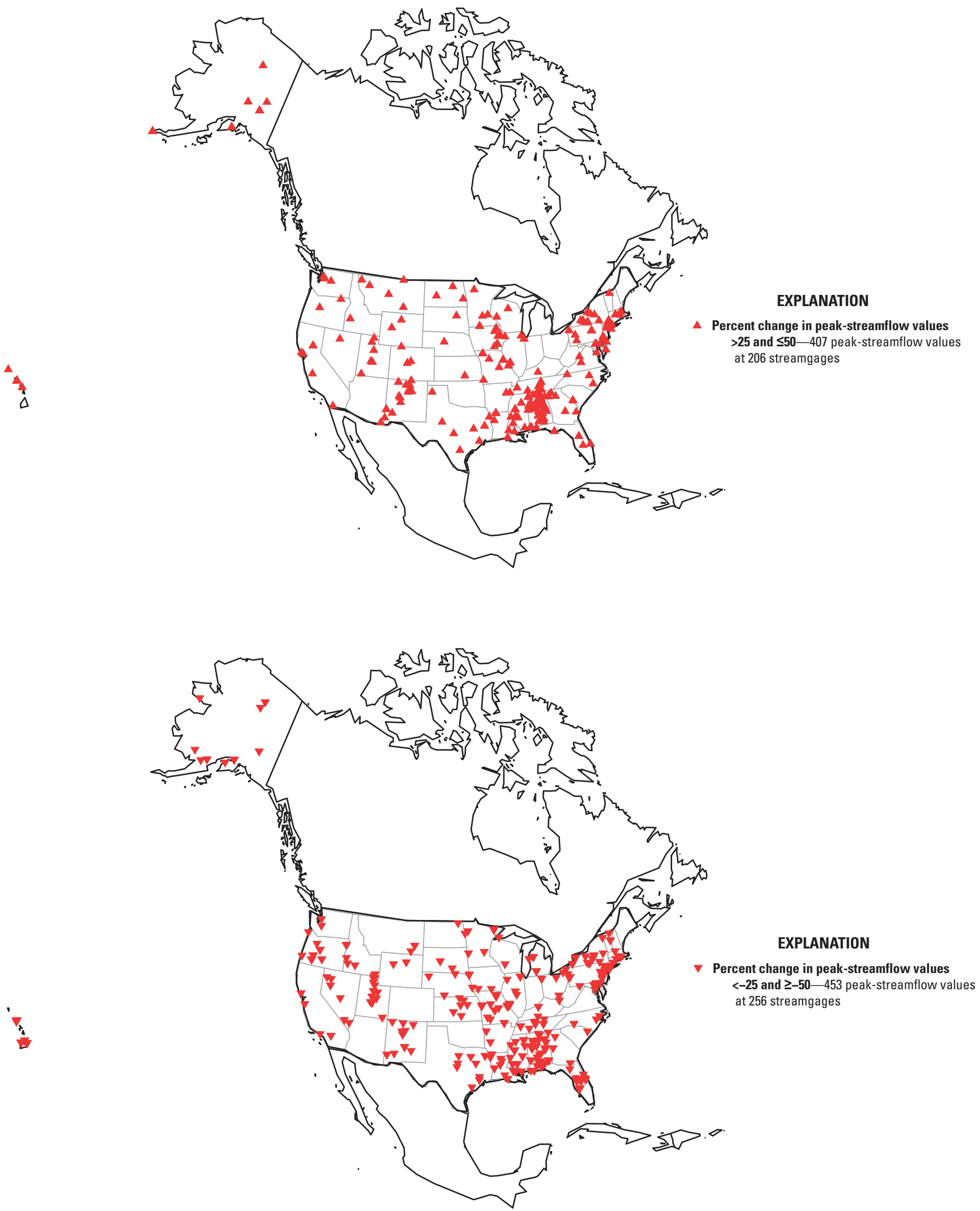

Figure 7. Cartograms of streamgages with absolute value of change in peak streamflow greater than 25 percent and less than or equal to 50 percent. Top cartogram shows streamgages with increases and bottom cartogram shows streamgages with decreases. 


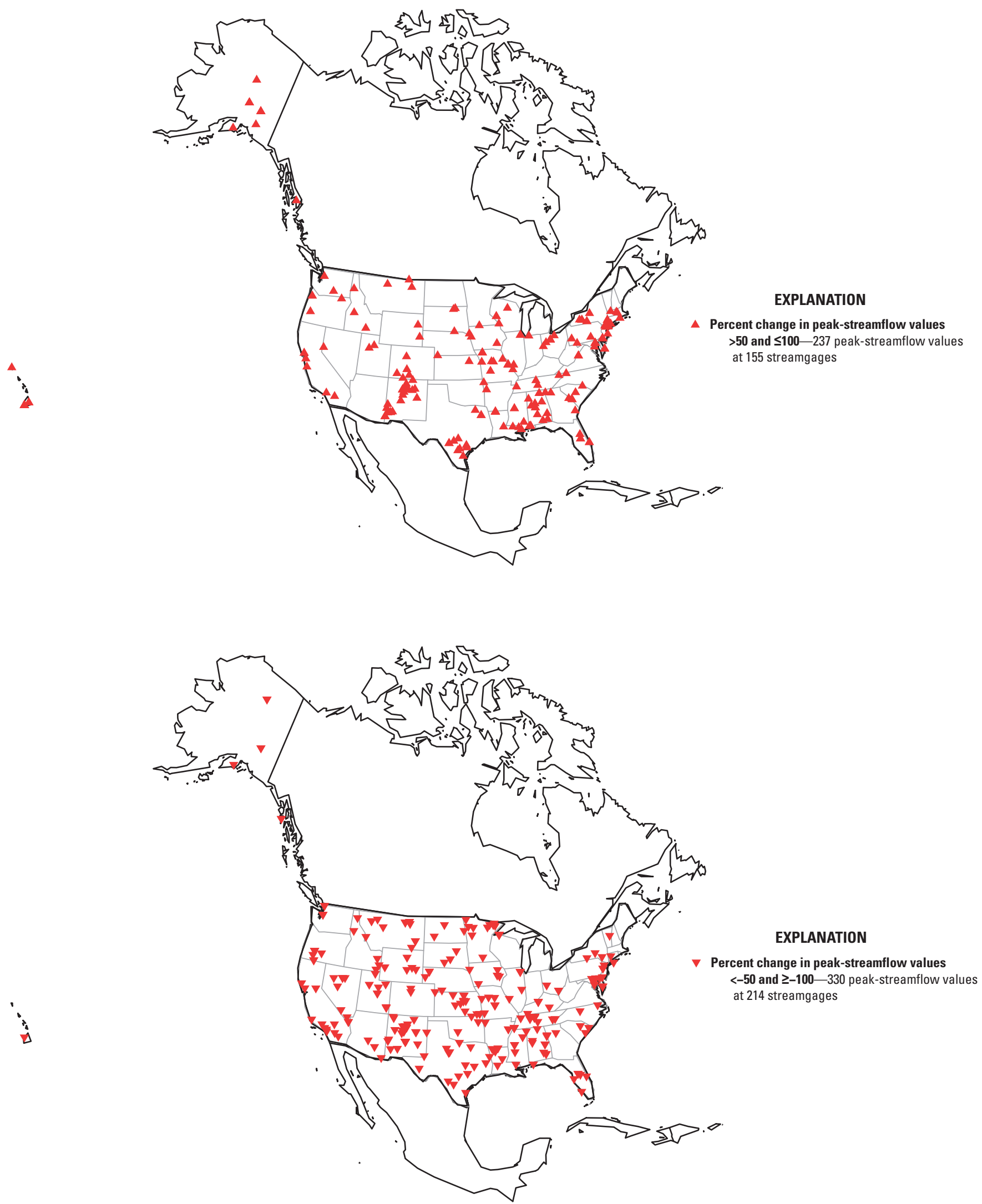

Figure 8. Cartograms of streamgages with absolute value of change in peak streamflow greater than 50 percent and less than or equal to 100 percent. Top cartogram shows streamgages with increases and bottom cartogram shows streamgages with decreases. 
i.

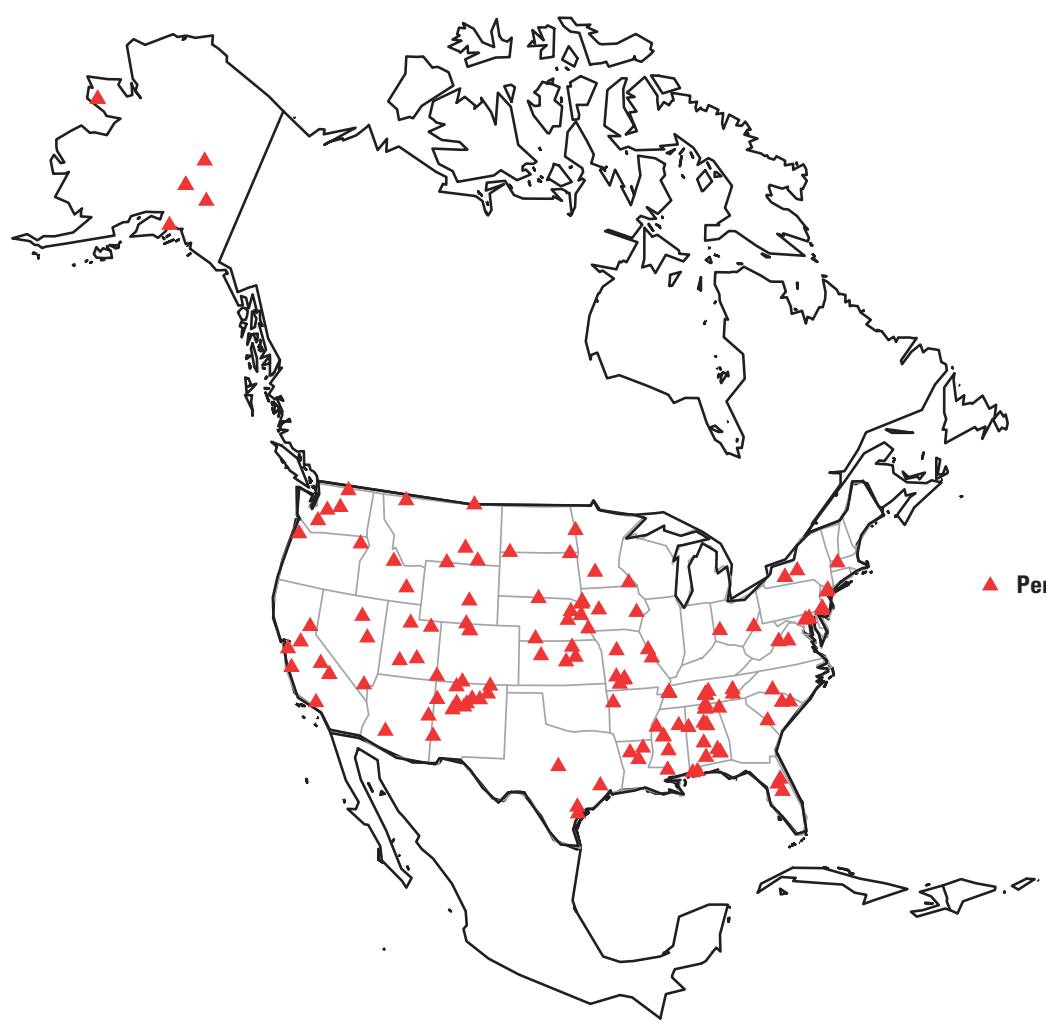

EXPLANATION

Percent change in peak-streamflow values $>100$ and $\leq 500-175$ peak-streamflow values at 135 streamgages

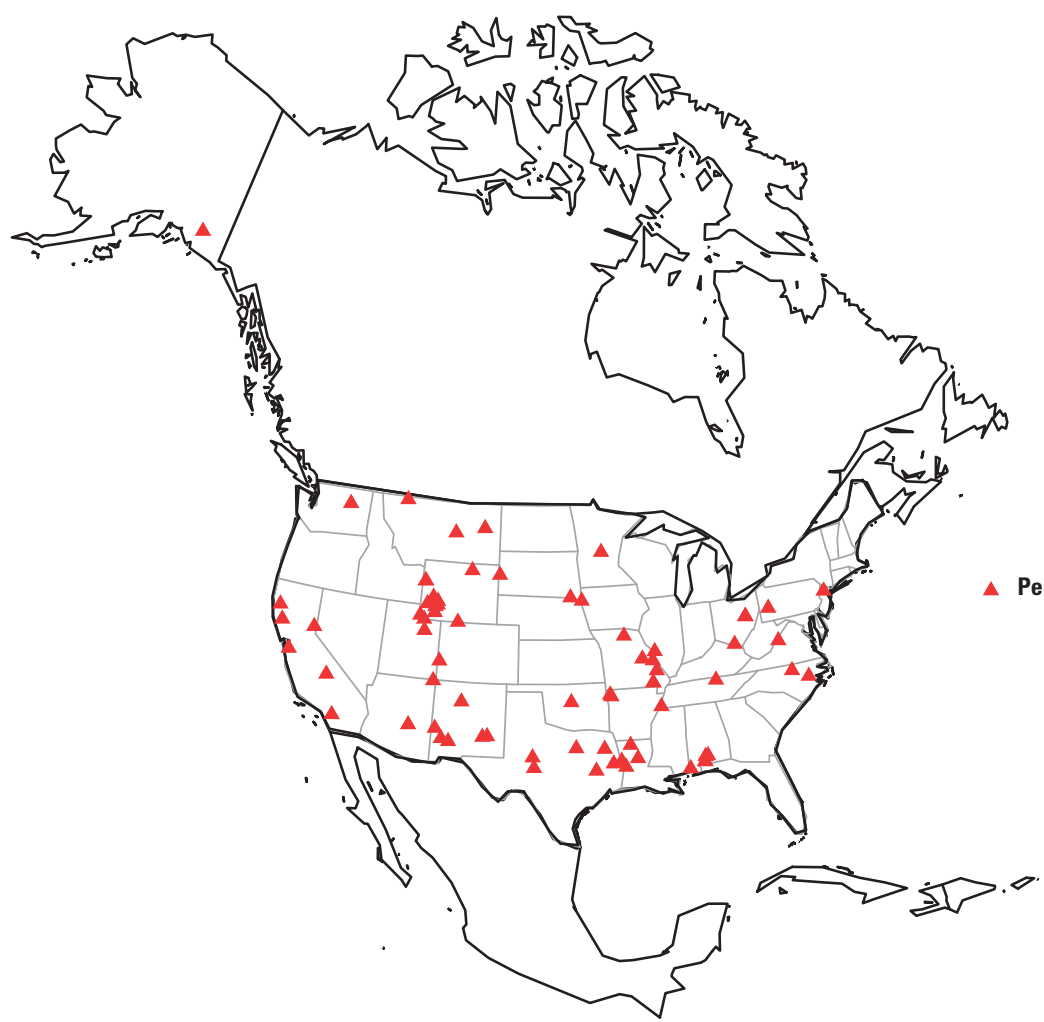

EXPLANATION

Percent change in peak-streamflow values $>\mathbf{5 0 0}$ and $\leq 1,000-73$ peak-streamflow values

$\because$ at 70 streamgages

Figure 9. Cartograms of streamgages with increases in peak streamflow greater than 100 percent and less than or equal to 500 percent and change in peak streamflow greater than 500 percent and less than or equal to 1,000 percent. 

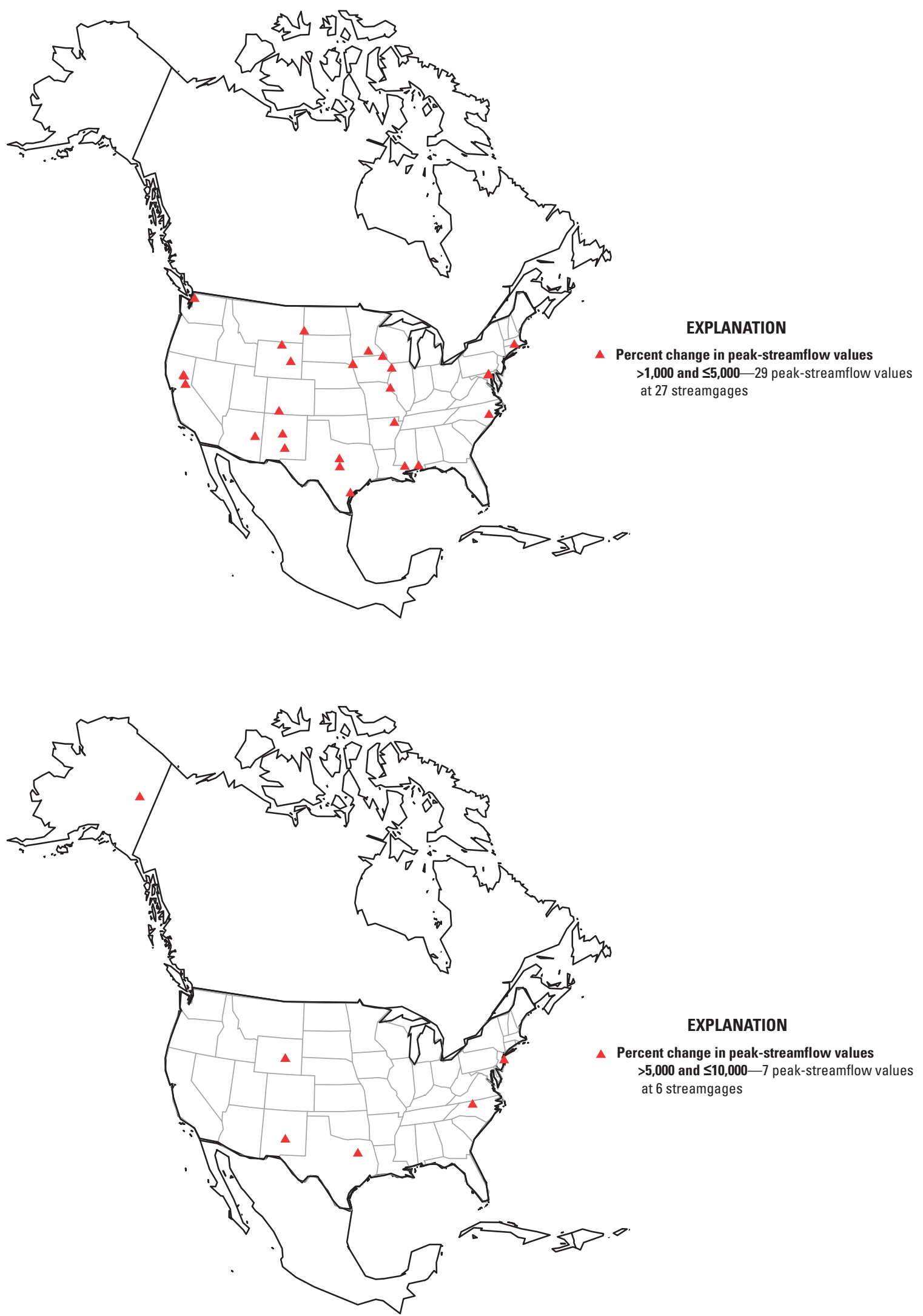

Figure 10. Cartograms of streamgages with increases in peak streamflow greater than 1,000 percent and less than or equal to 5,000 percent (see table 4) and change in peak streamflow greater than 5,000 percent and less than or equal to 10,000 percent (see table 5). 


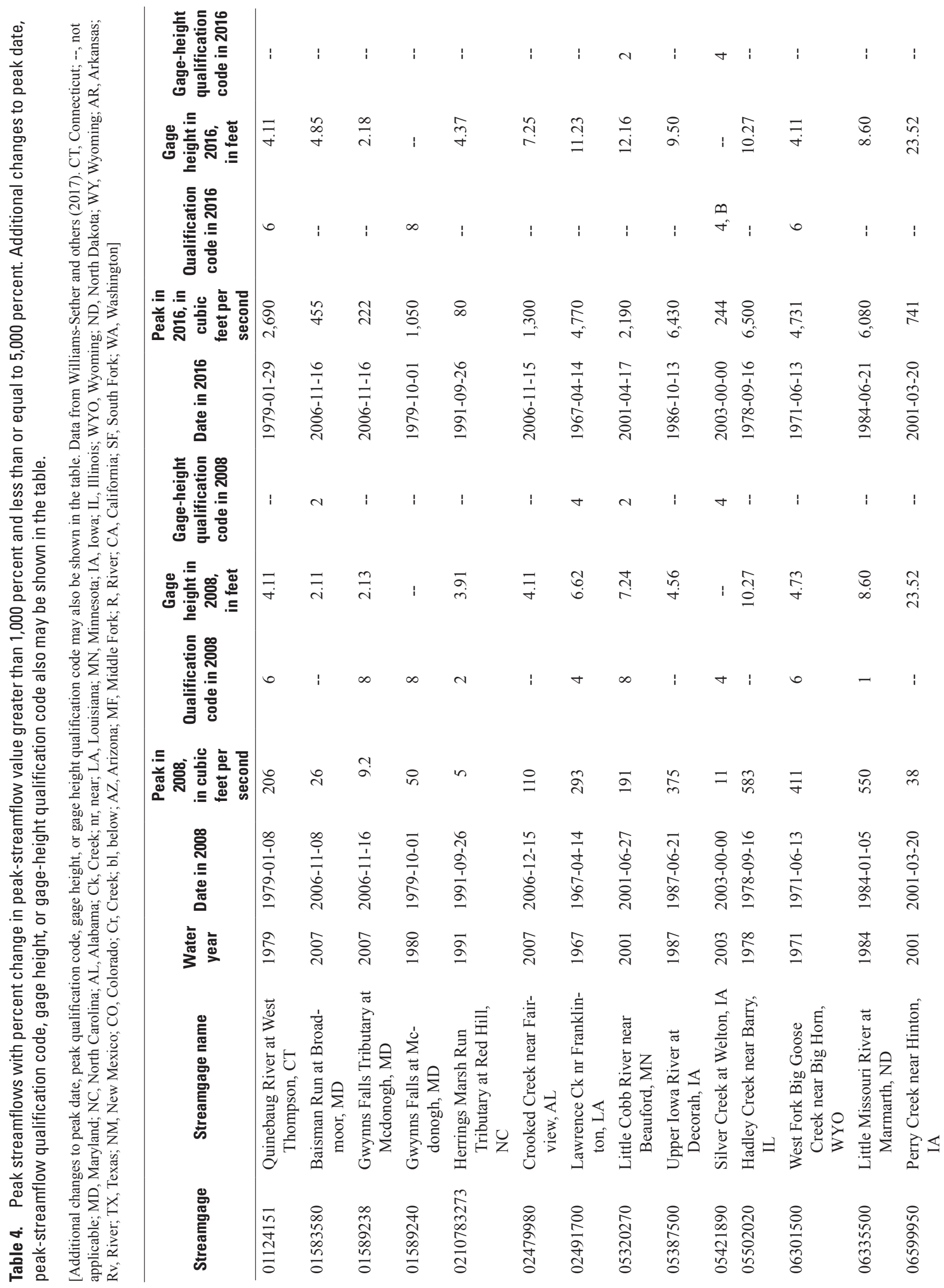




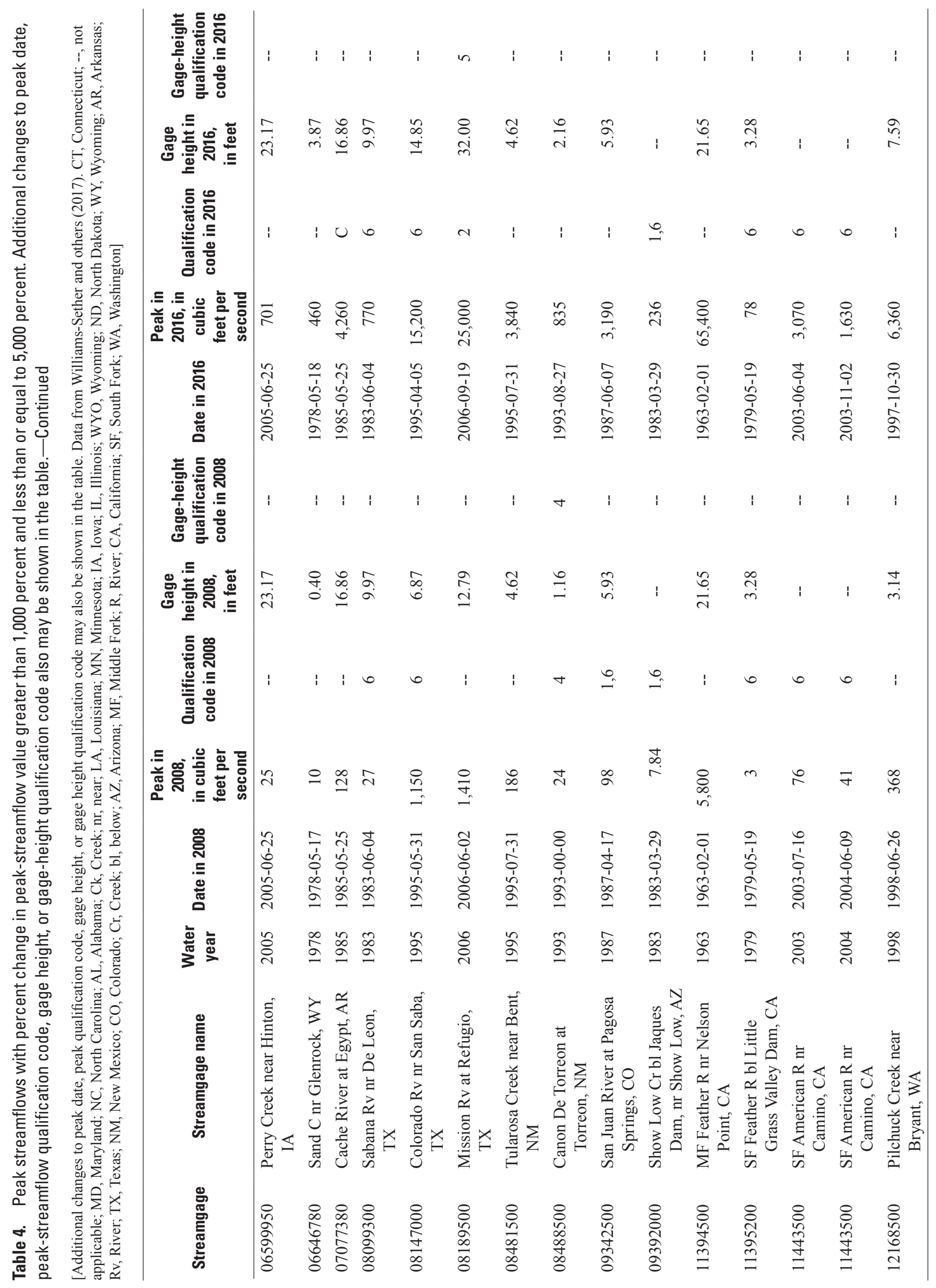




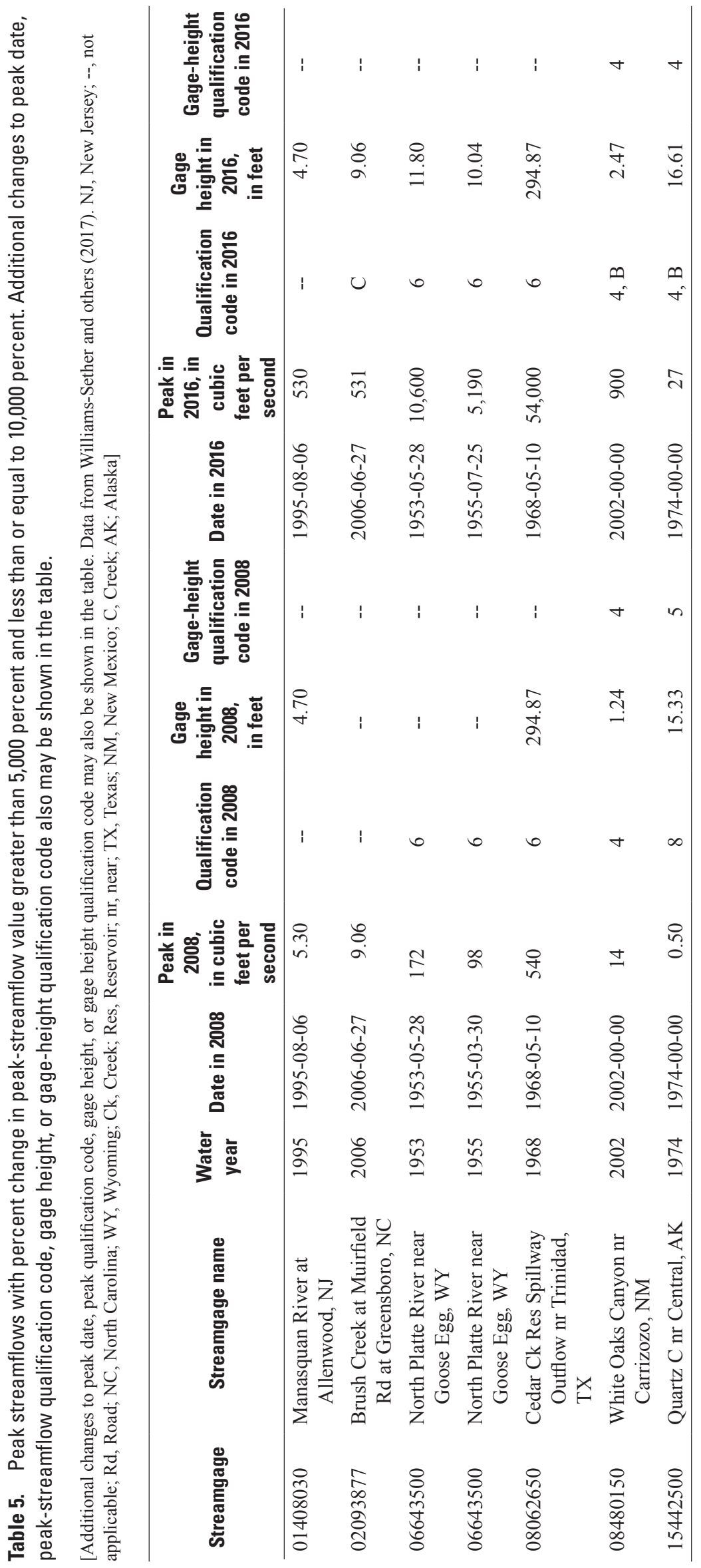



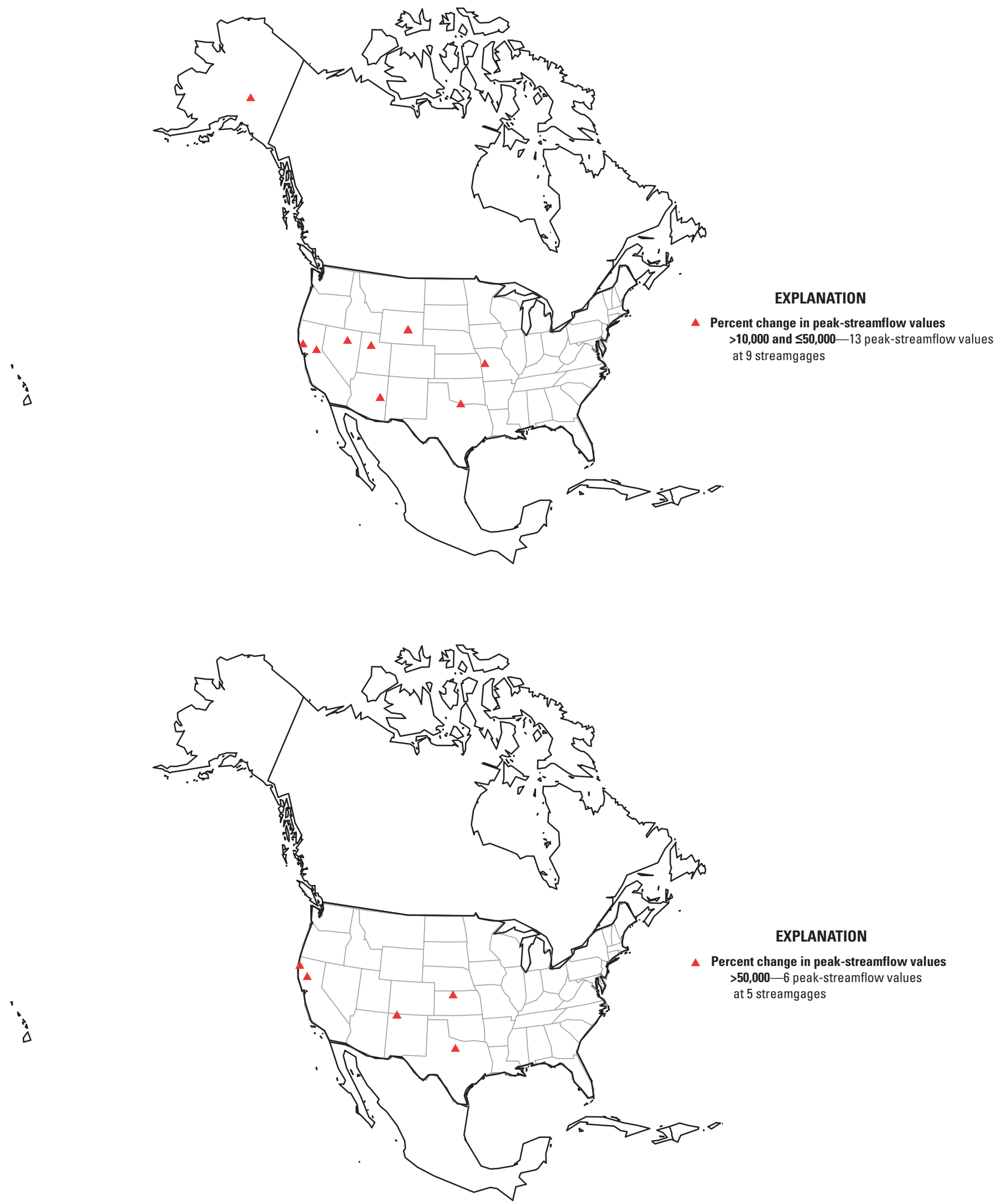

\section{EXPLANATION}

Percent change in peak-streamflow values $>\mathbf{5 0 , 0 0 0}-6$ peak-streamflow values at 5 streamgages

$\therefore$

Figure 11. Cartograms of streamgages with percent change in peak streamflow greater than 10,000 percent and less than or equal to 50,000 percent (see table 6) and change in peak streamflow greater than 50,000 percent (see table 7). 


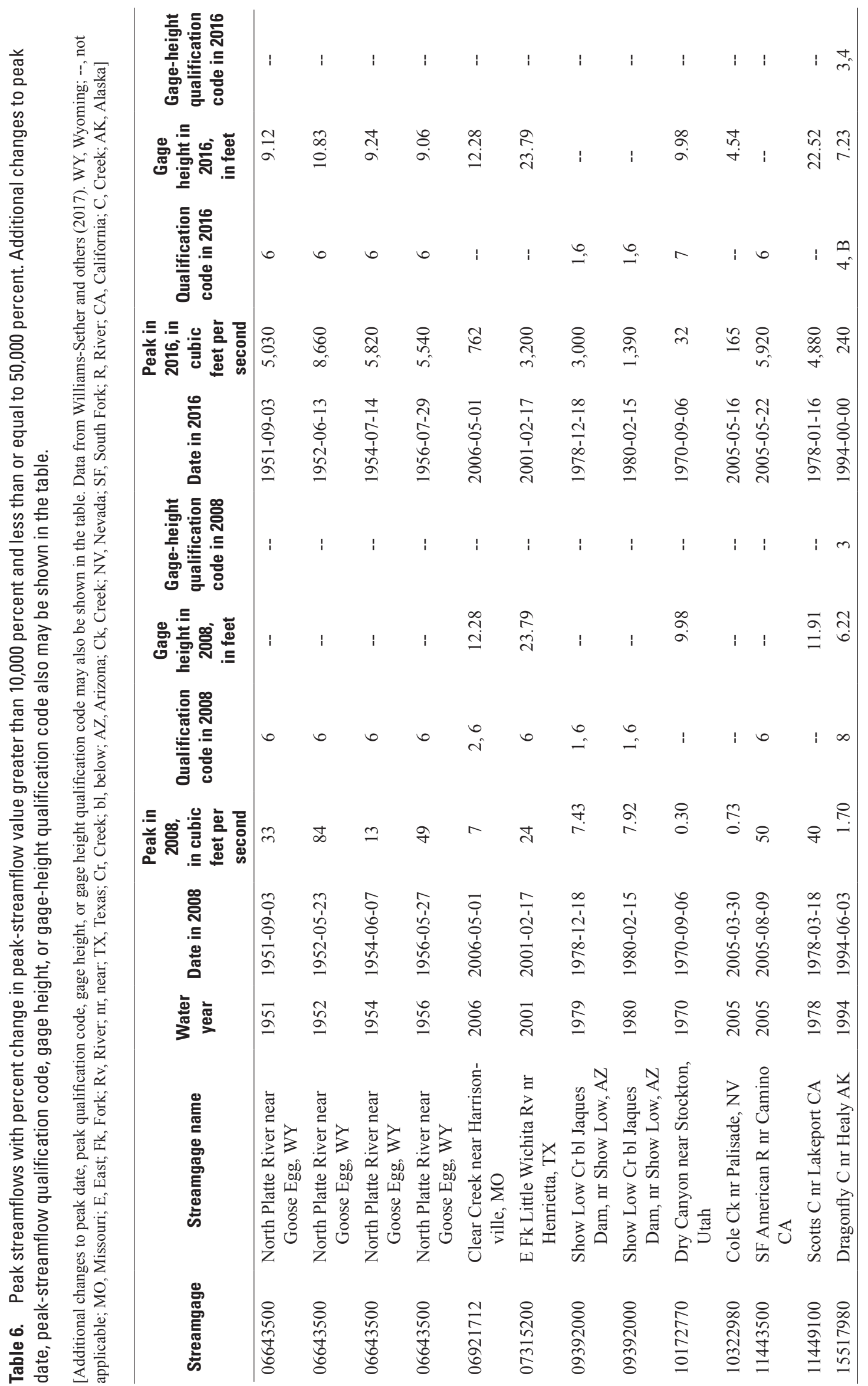




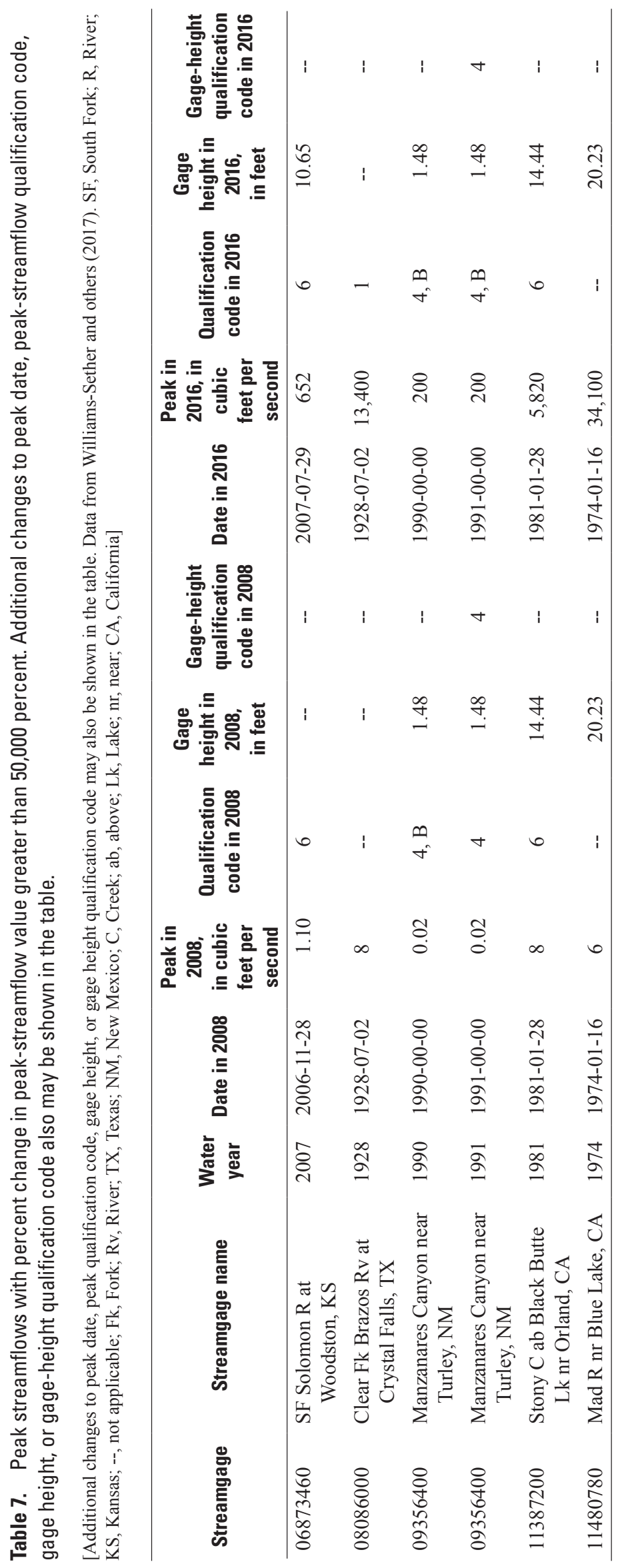




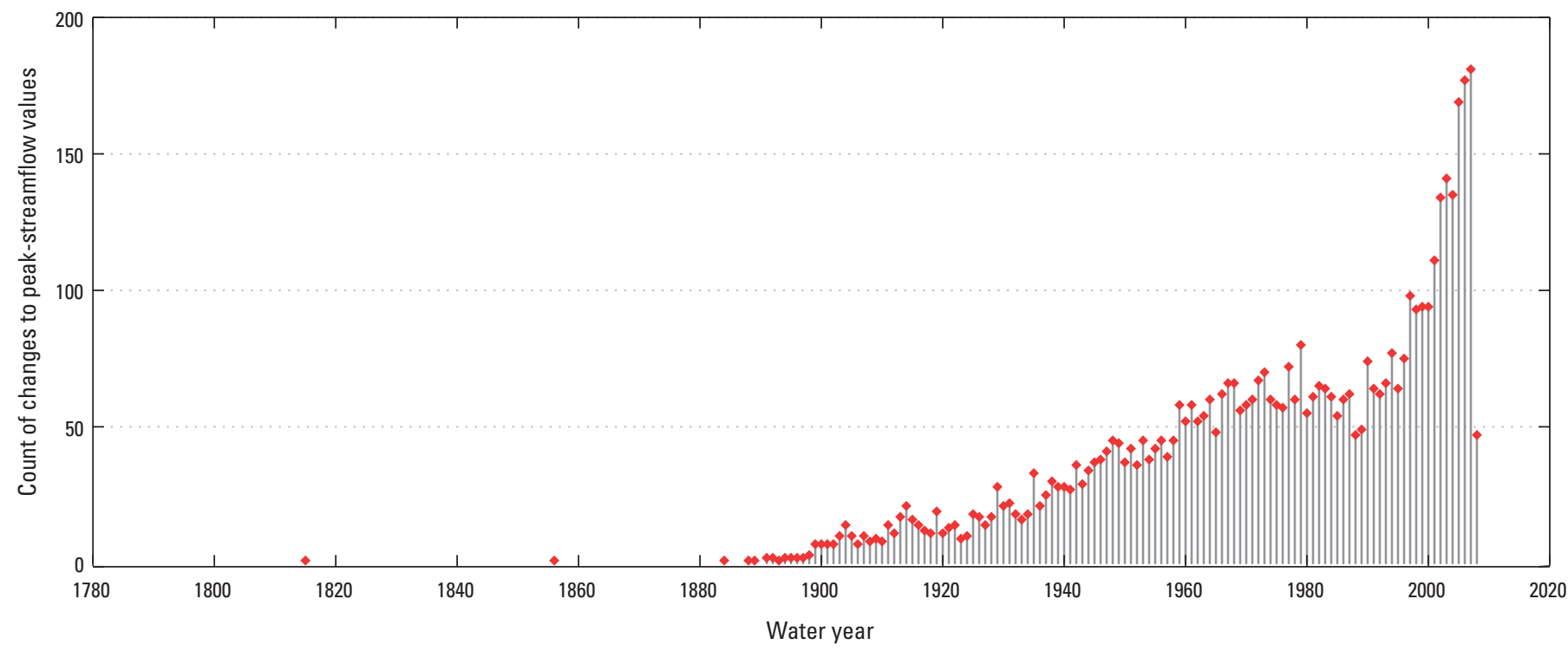

Figure 12. Count of changes to peak-streamflow values by water year. 

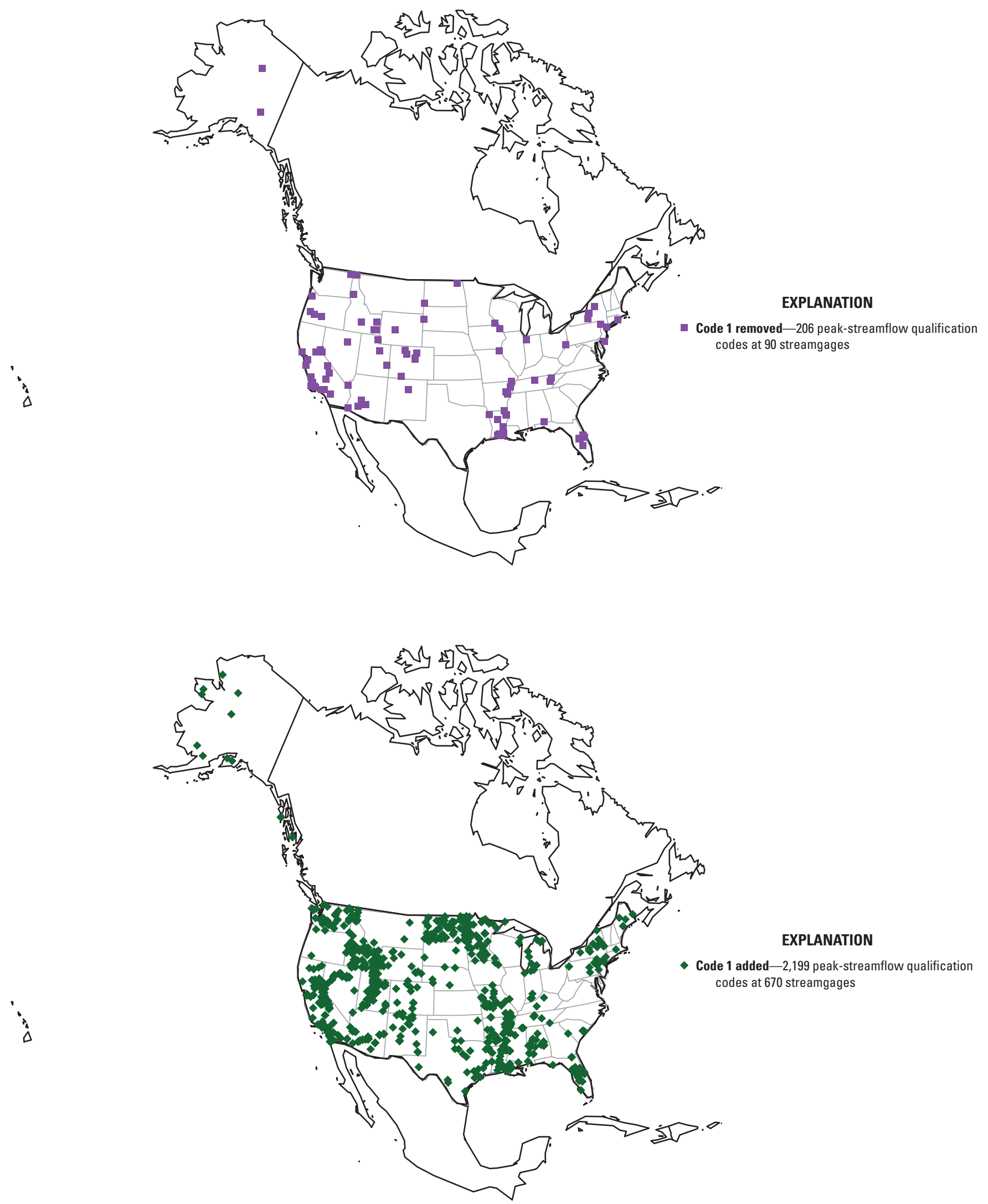

EXPLANATION

2,199 peak-streamflow qualification codes at 670 streamgages

Figure 13. Cartograms indicating streamgages with peak-streamflow qualification code 1 removed (purple squares) or added (green diamonds). 
$\Delta$
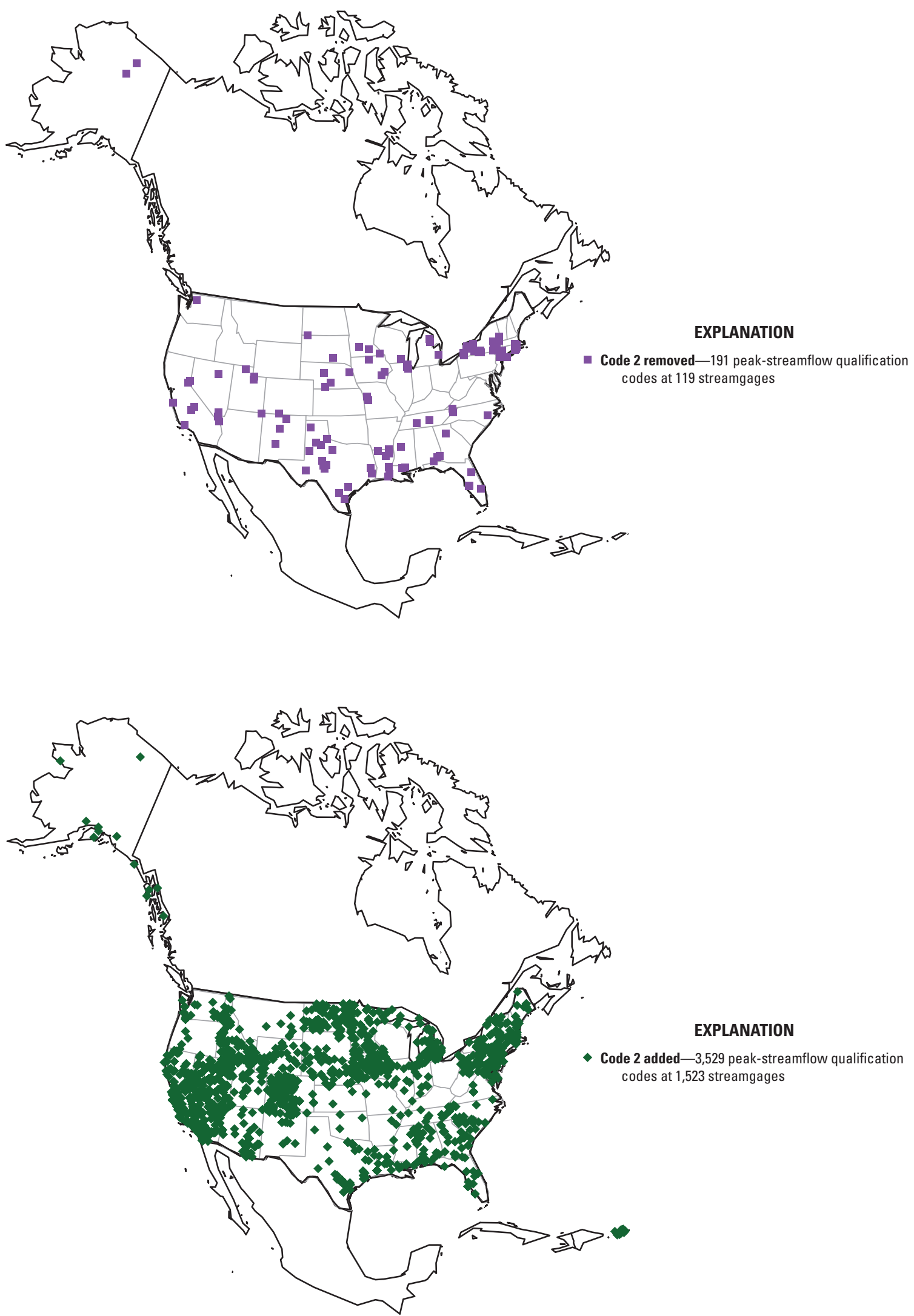

EXPLANATION

: 2 added-3,529 peak-streamflow qualification codes at 1,523 streamgages

Figure 14. Cartograms indicating streamgages with peak-streamflow qualification code 2 removed (purple squares) or added (green diamonds). 

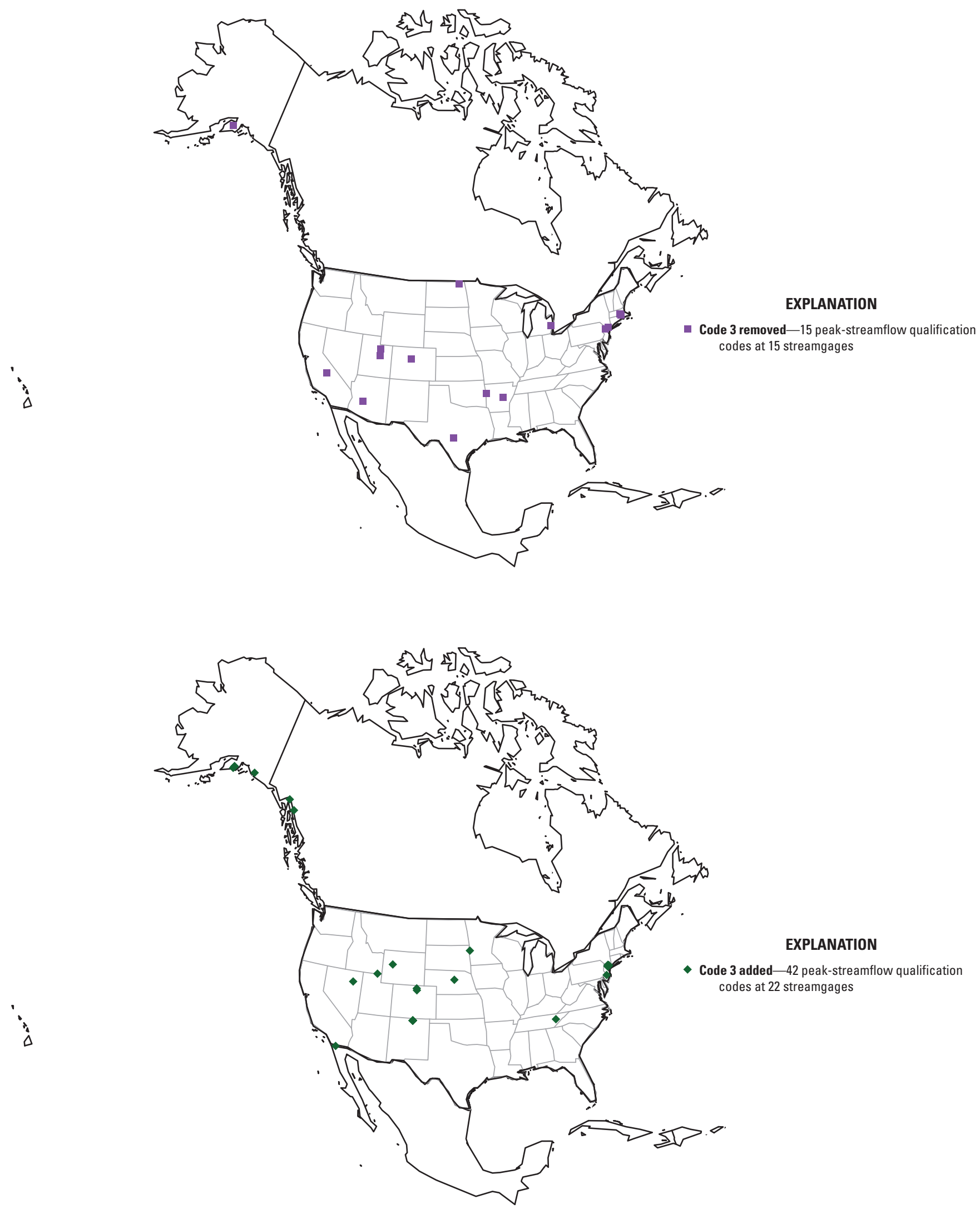

Figure 15. Cartograms indicating streamgages with peak-streamflow qualification code 3 removed (purple squares, see table 8) or added (green diamonds). 


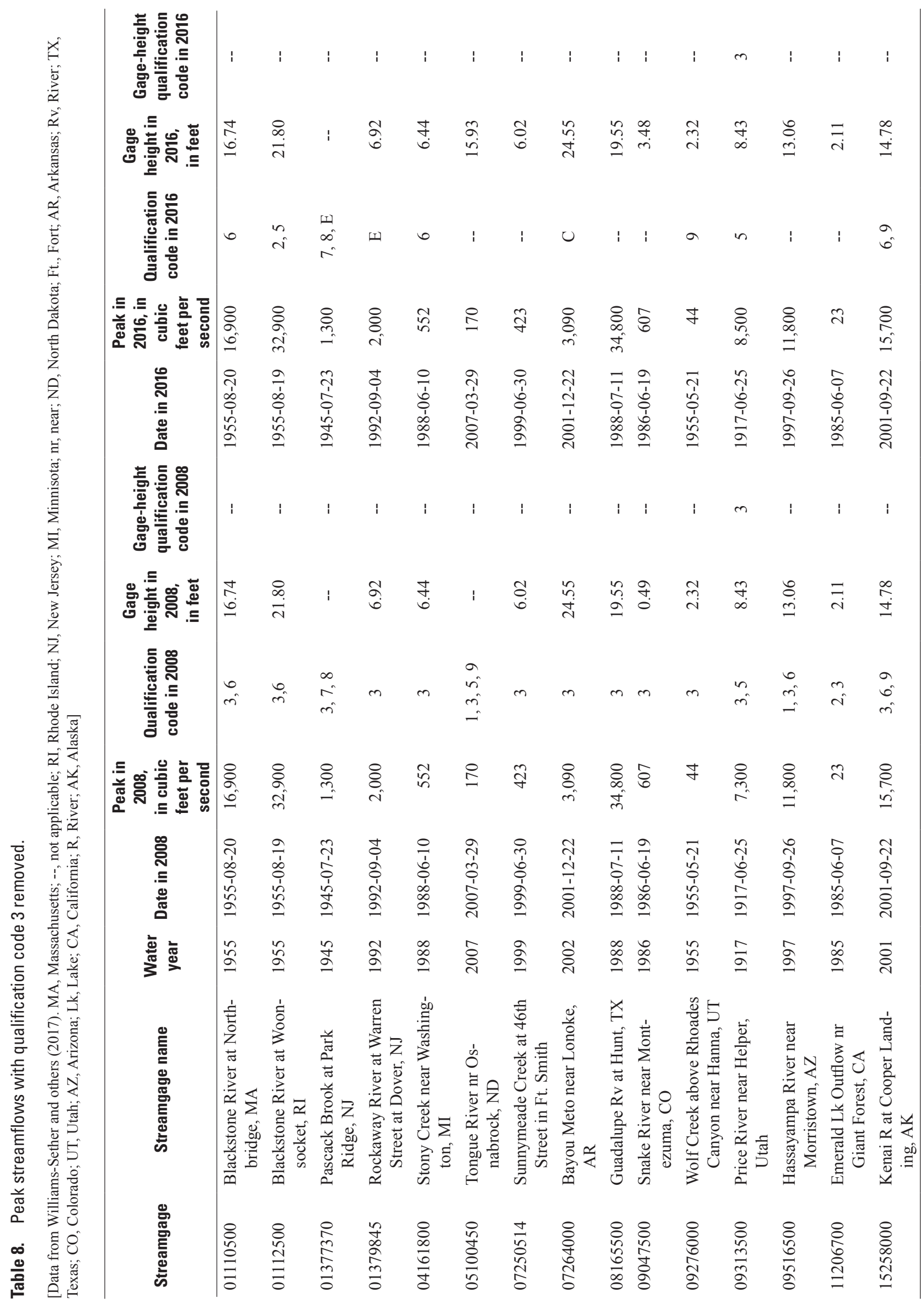



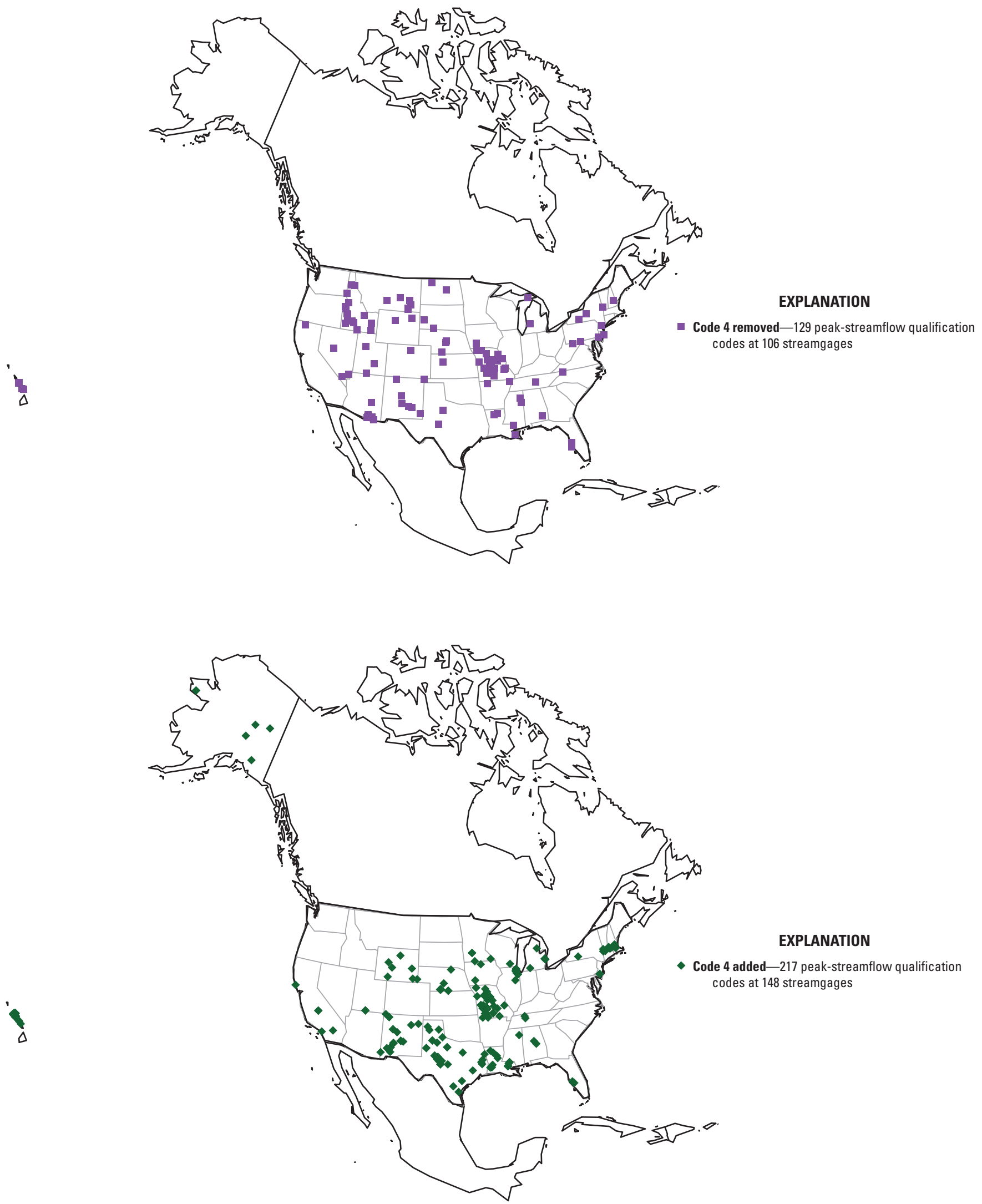

$\Delta$ codes at 148 streamgages

Figure 16. Cartograms indicating streamgages with peak-streamflow qualification code 4 removed (purple squares) or added (green diamonds). 


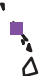
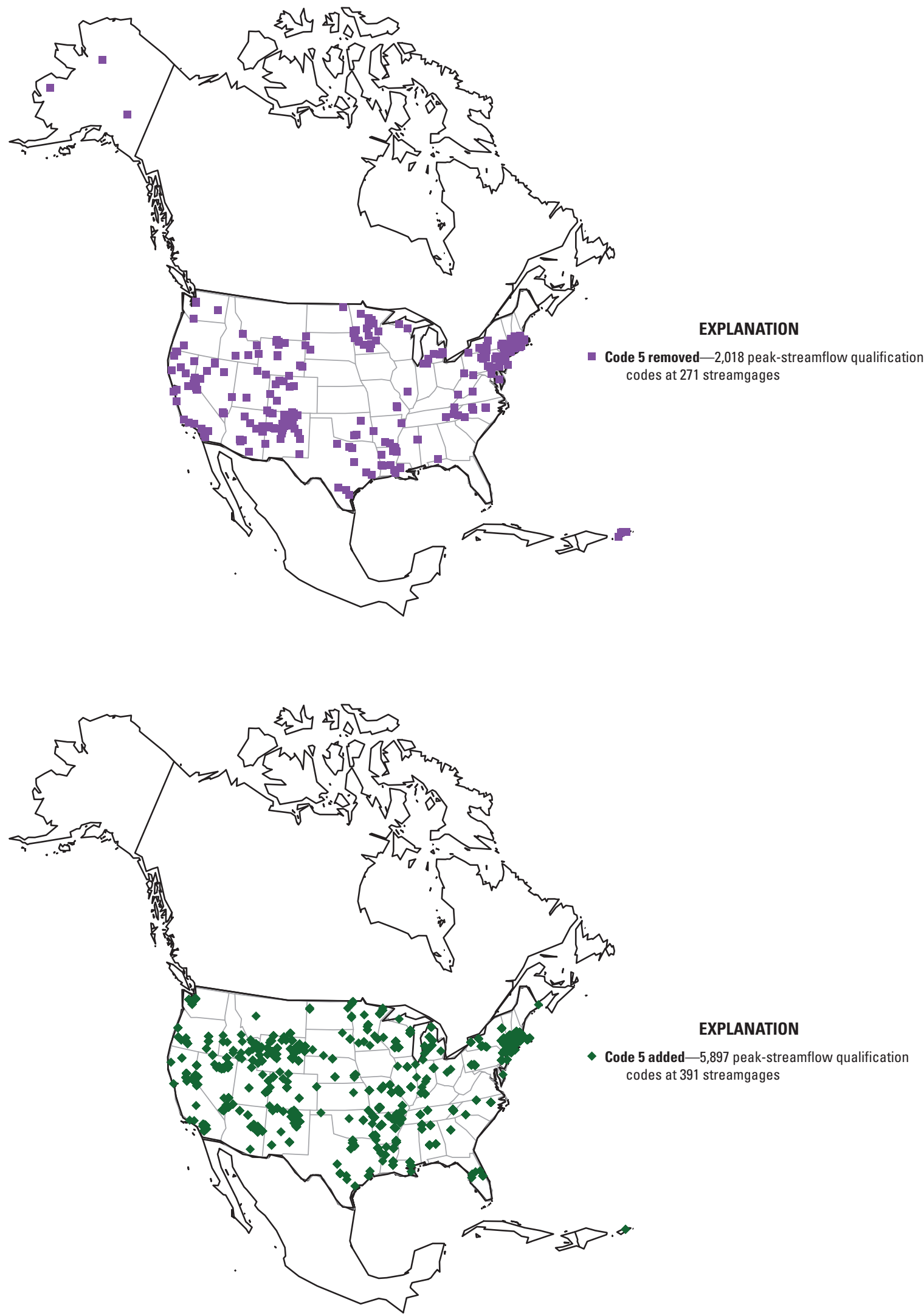

EXPLANATION

is codes at 391 streamgages

Figure 17. Cartograms indicating streamgages with peak-streamflow qualification code 5 removed (purple squares) or added (green diamonds). 

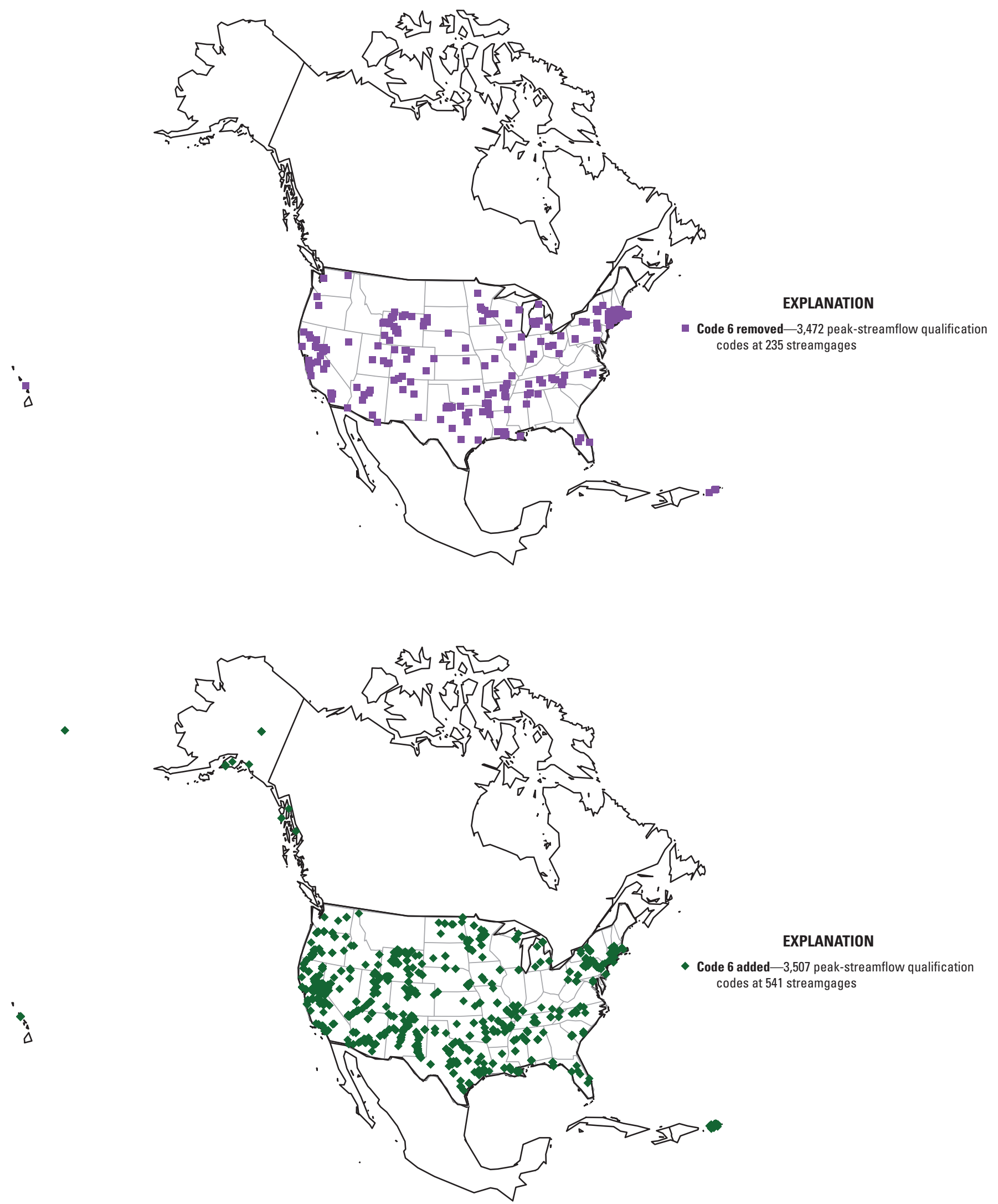

Figure 18. Cartograms indicating streamgages with peak-streamflow qualification code 6 removed (purple squares) or added (green diamonds). 
is
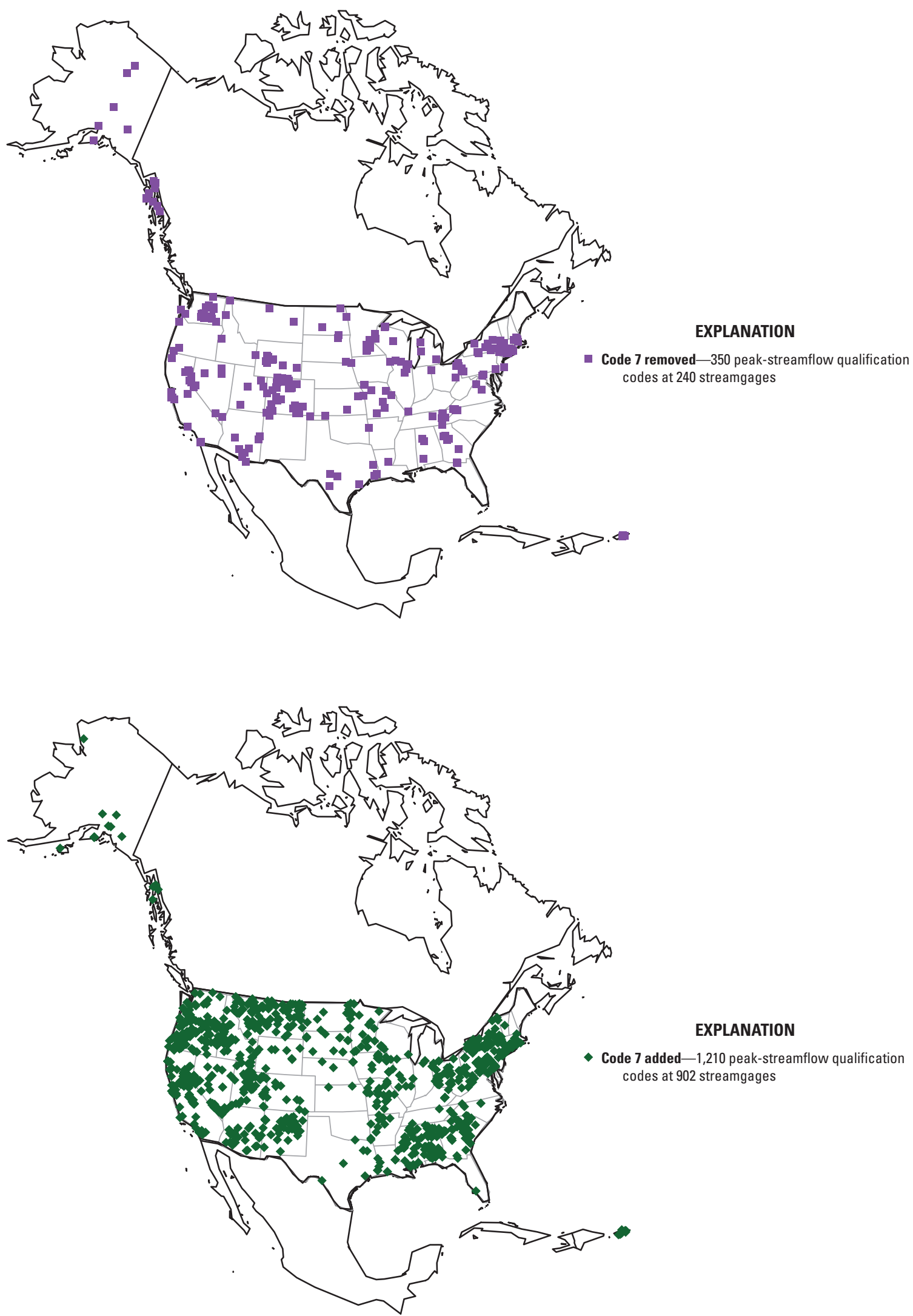

EXPLANATION

$\theta$ codes at 902 streamgages

Figure 19. Cartograms indicating streamgages with peak-streamflow qualification code 7 removed (purple squares) or added (green diamonds). 

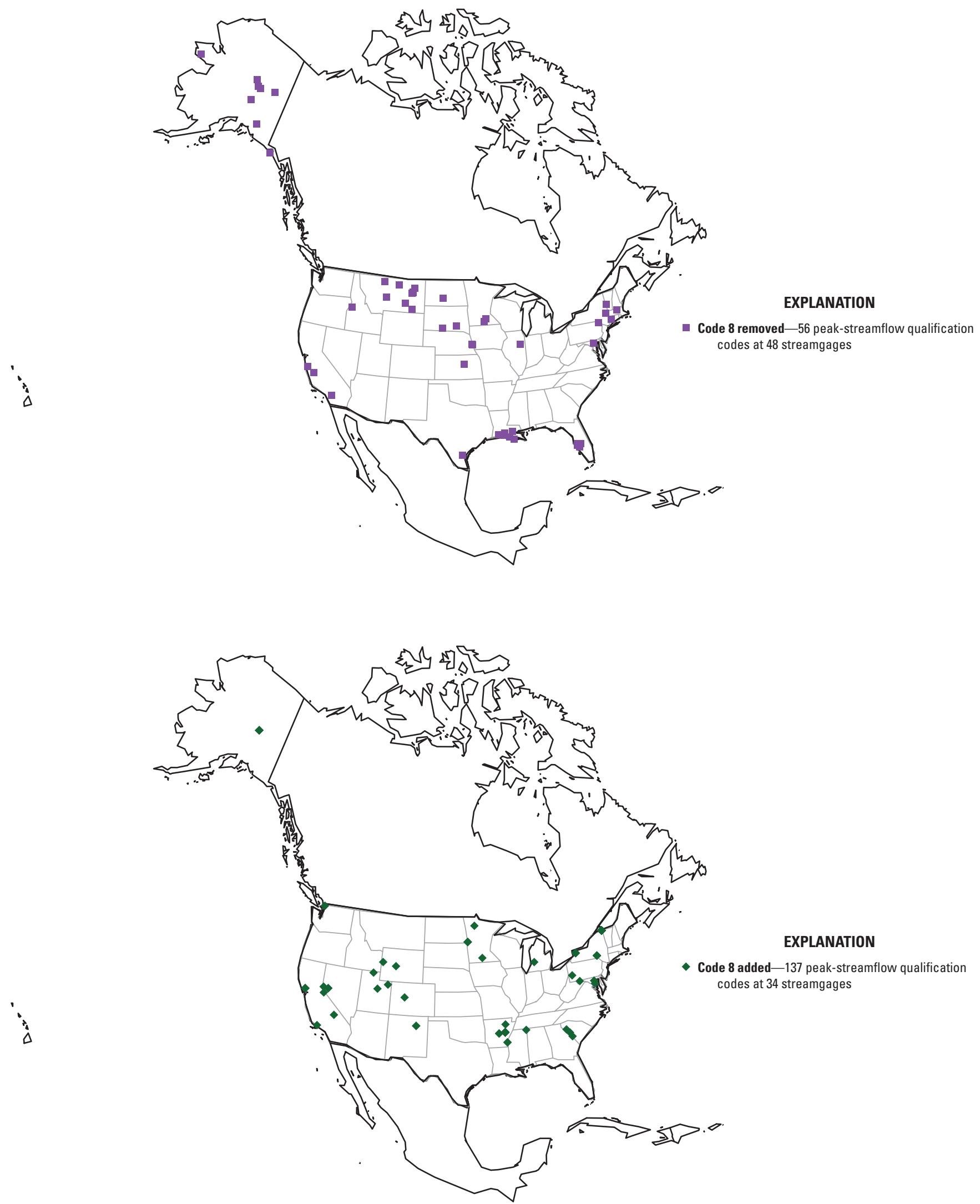

Figure 20. Cartograms indicating streamgages with peak-streamflow qualification code 8 removed (purple squares) or added (green diamonds). 
$\because$
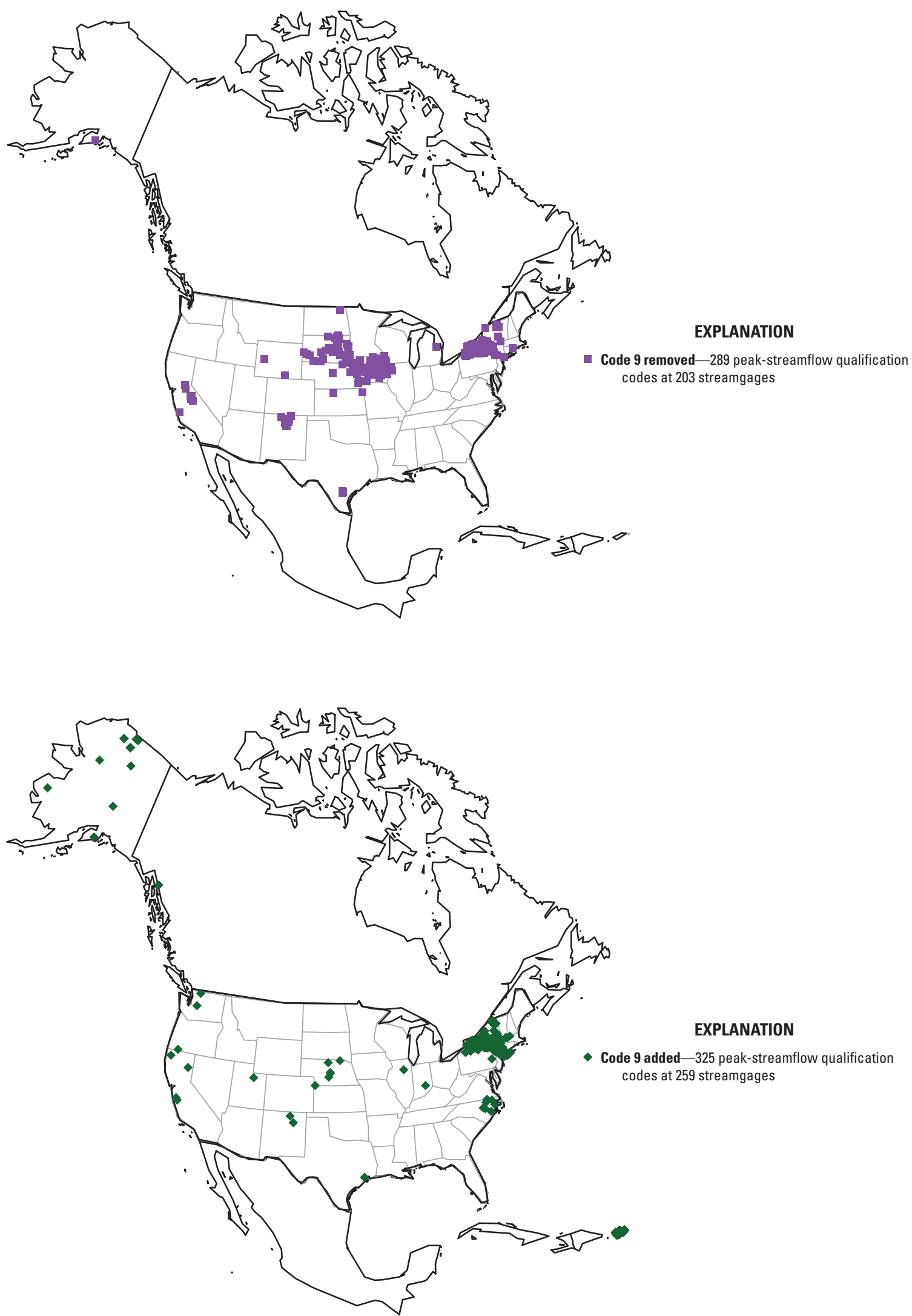

EXPLANATION

$\because$ codes at 259 streamgages

Figure 21. Cartograms indicating streamgages with peak-streamflow qualification code 9 removed (purple squares) or added (green diamonds). 


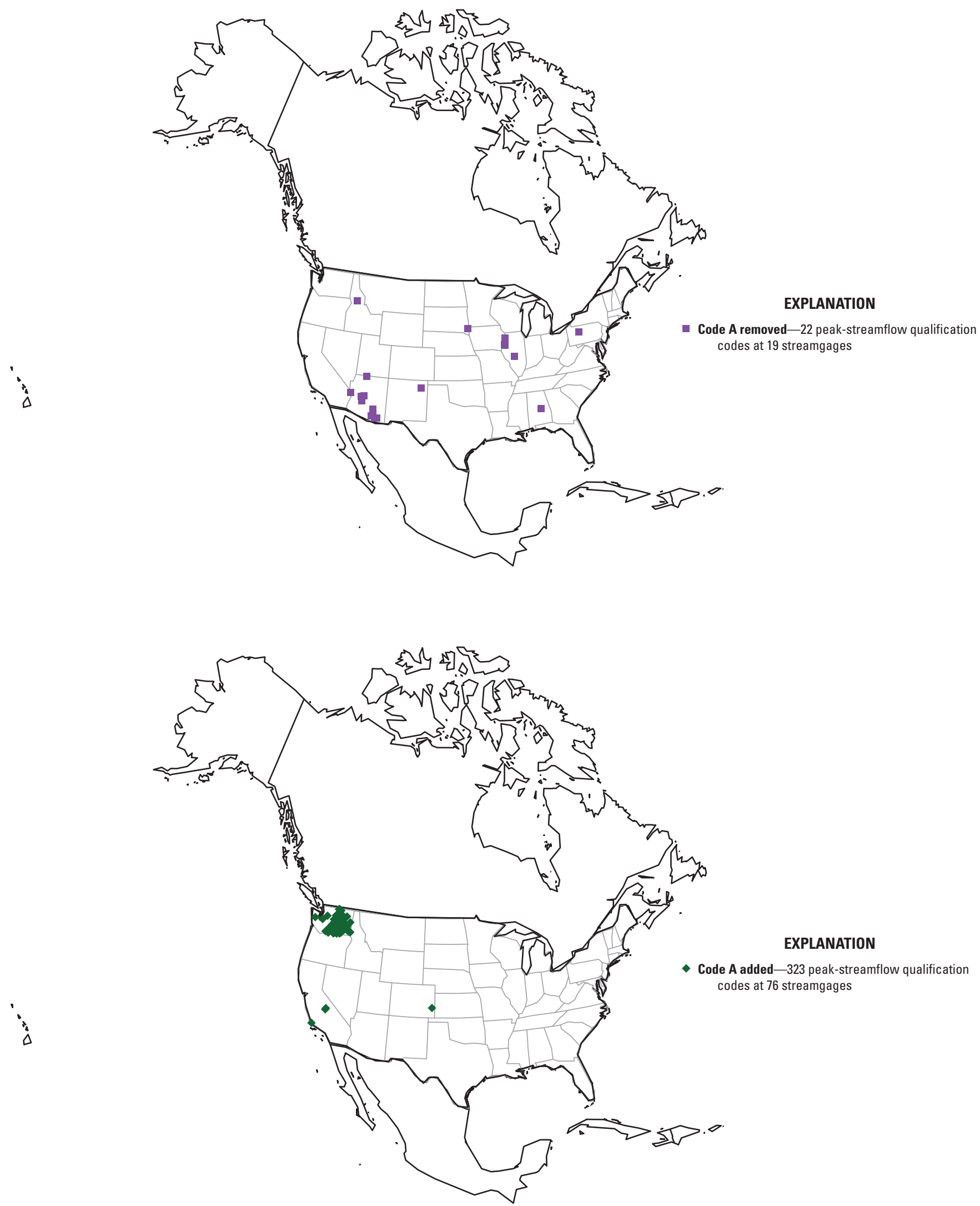

Figure 22. Cartograms indicating streamgages with peak-streamflow qualification code A removed (purple squares, see table 9) or added (green diamonds). 


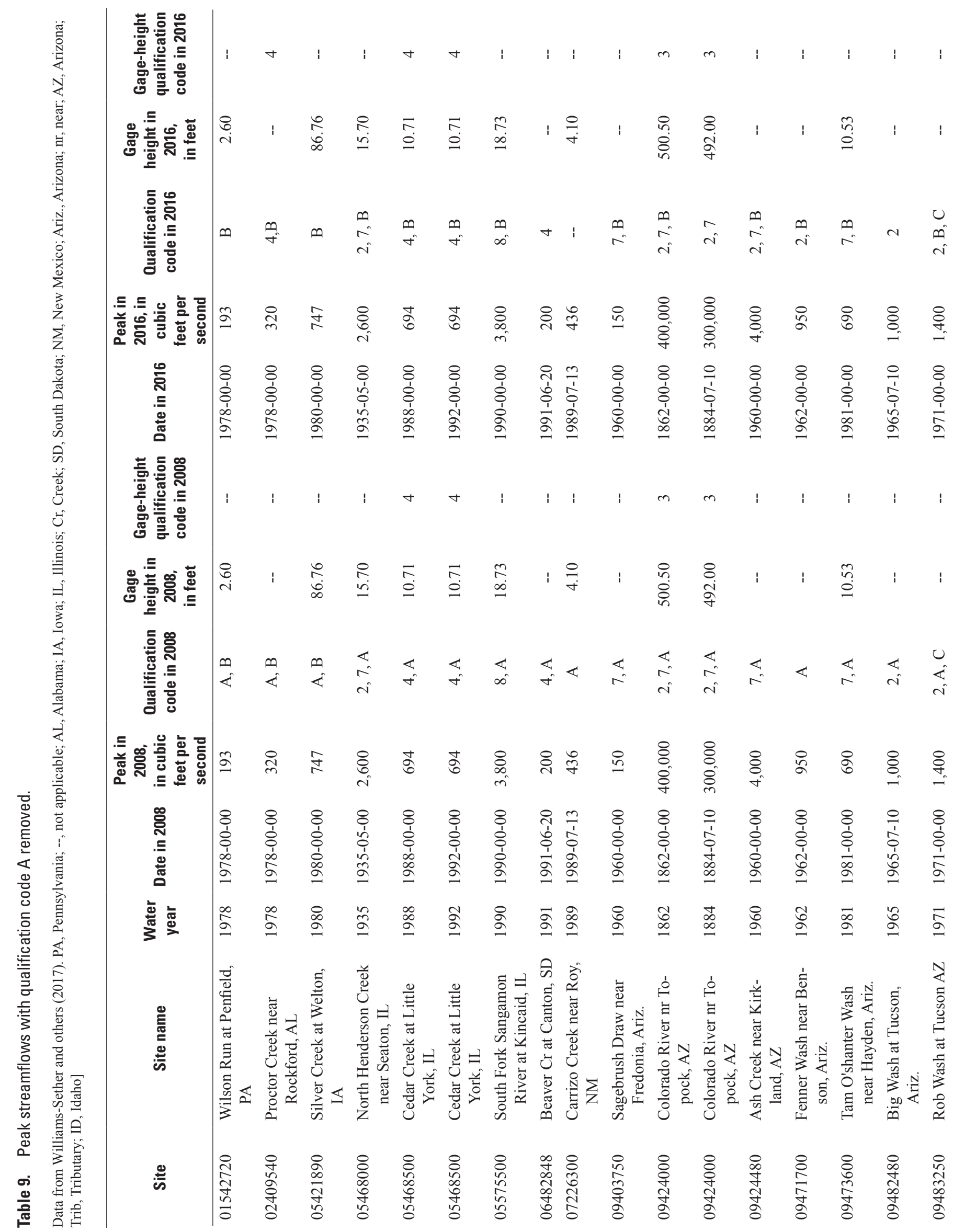




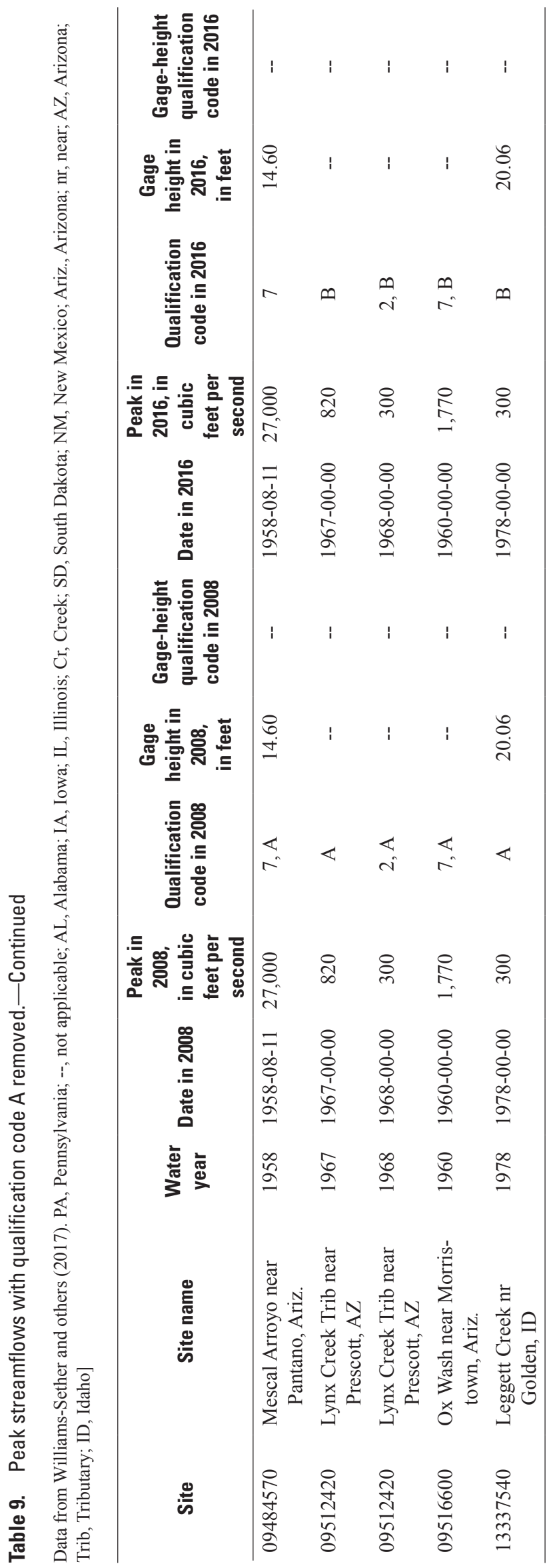


$\because$
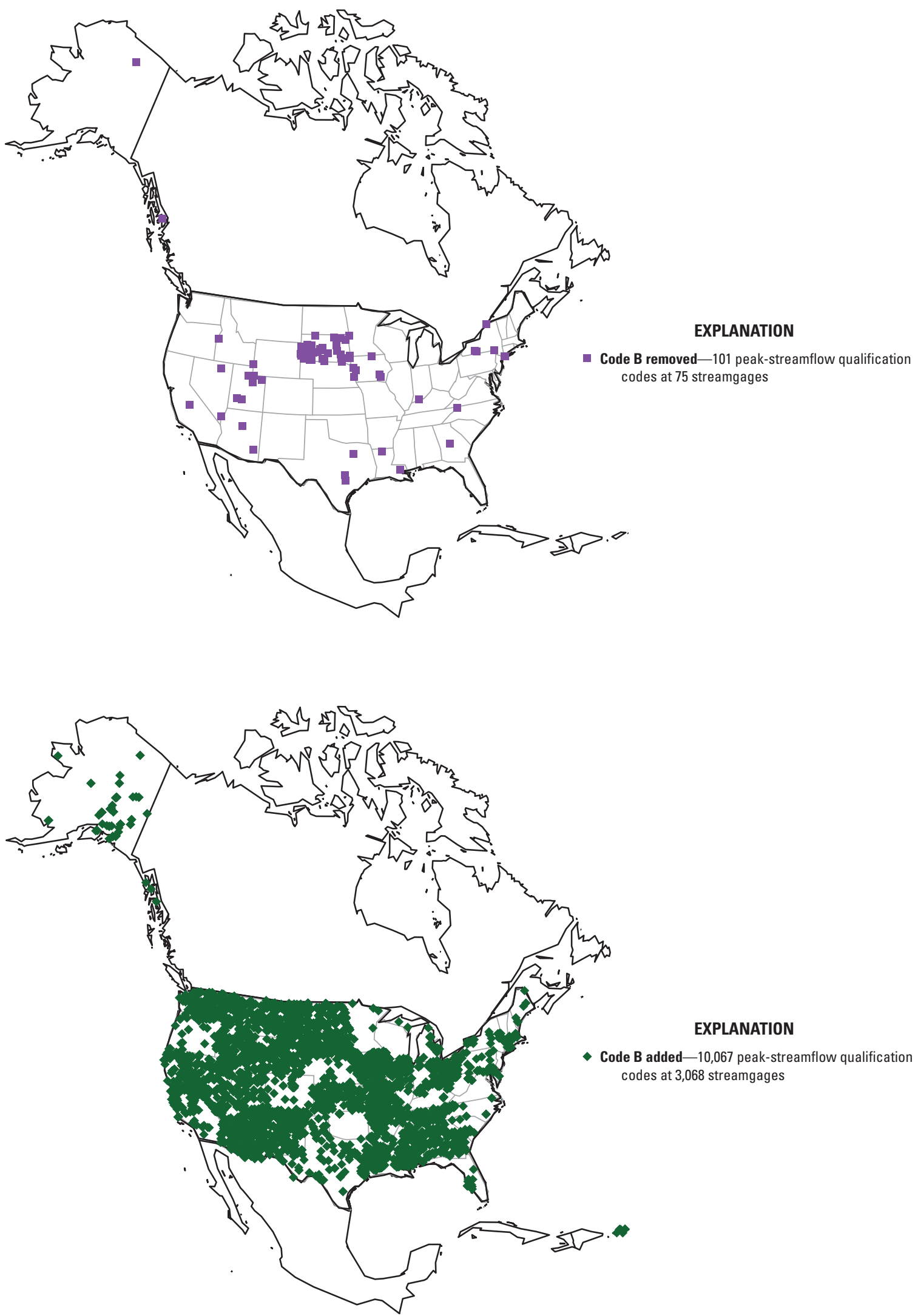

EXPLANATION codes at 3,068 streamgages

Figure 23. Cartograms indicating streamgages with peak-streamflow qualification code B removed (purple squares) or added (green diamonds). 

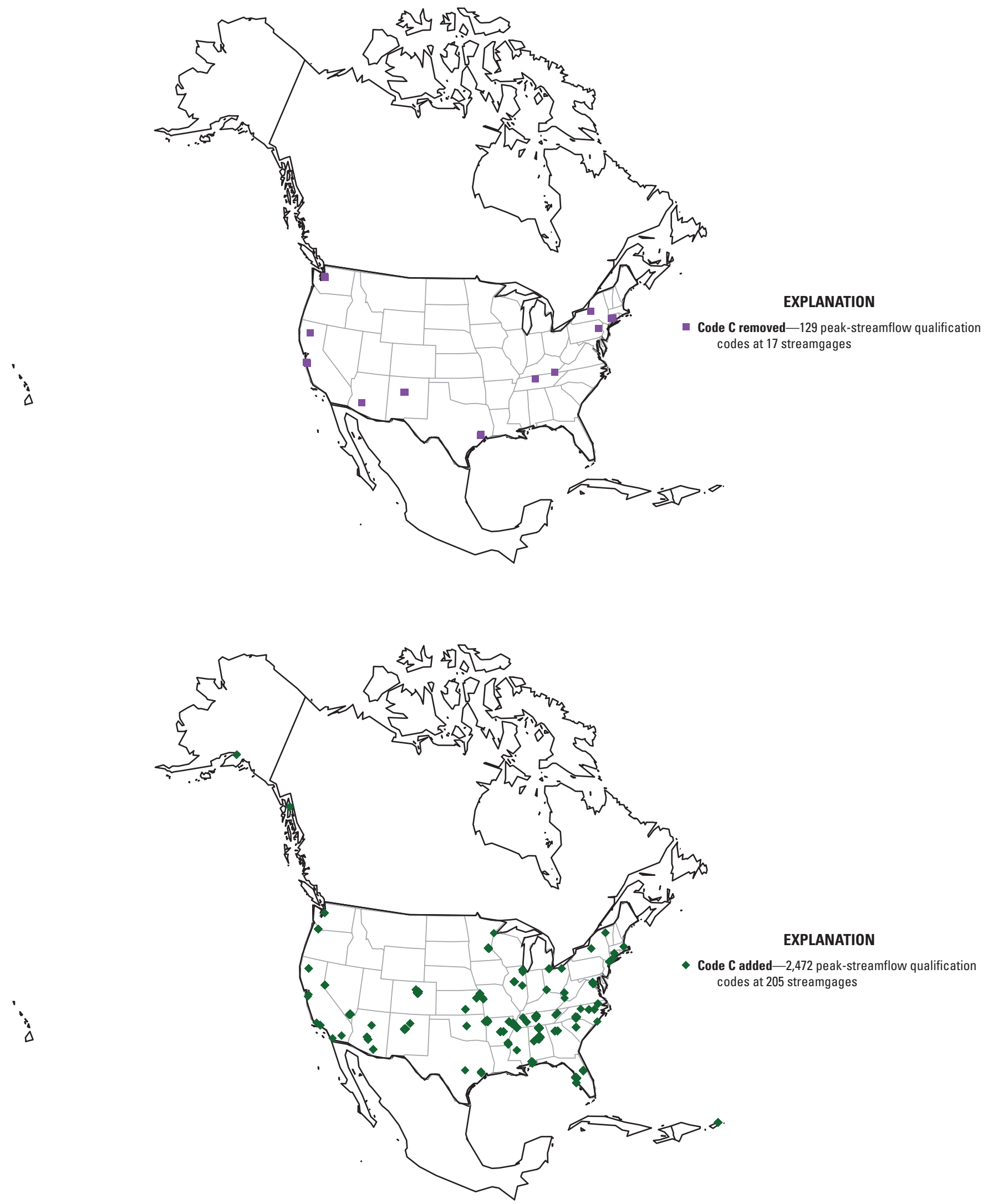

Figure 24. Cartograms indicating streamgages with peak-streamflow qualification code C removed (purple squares) or added (green diamonds). 

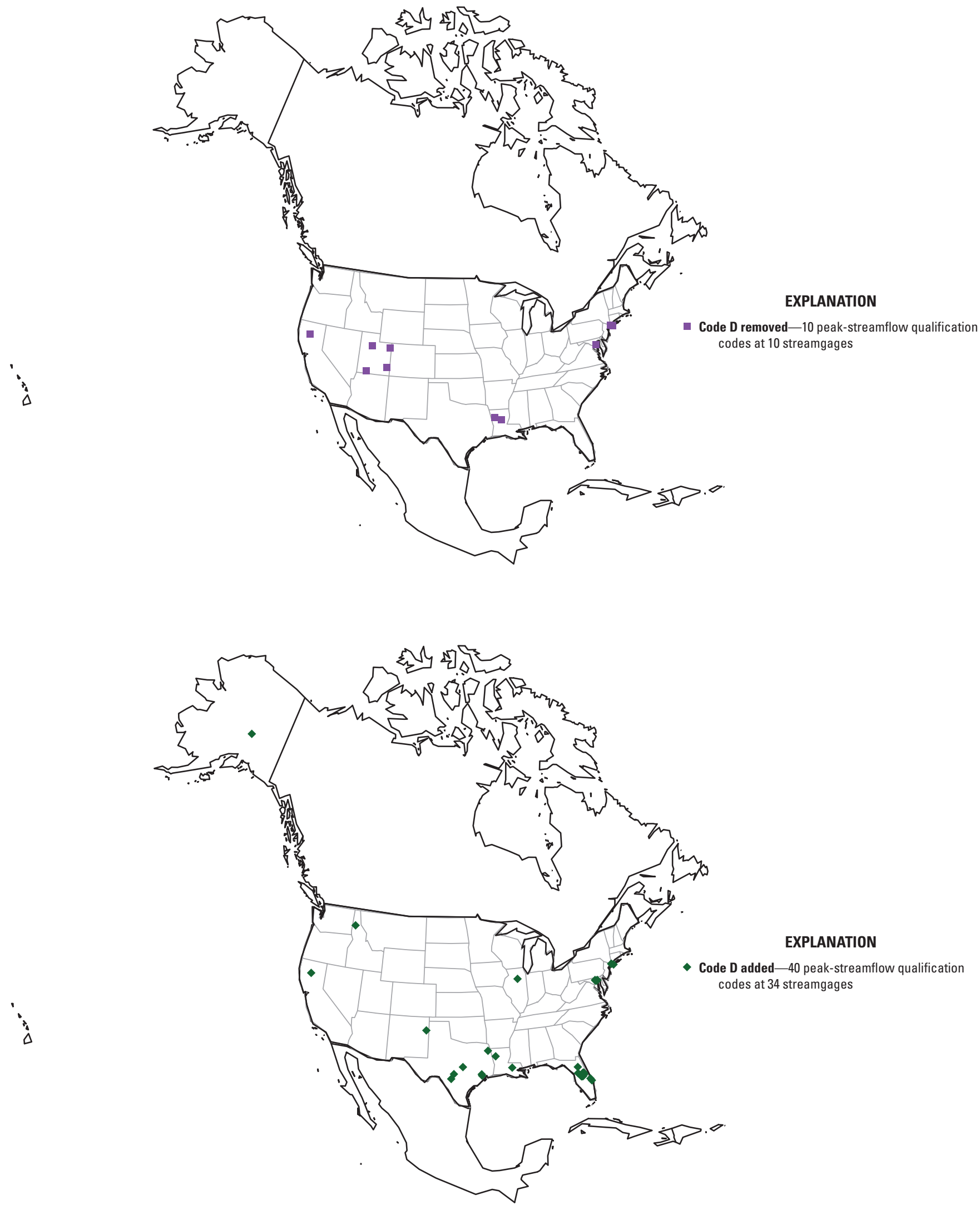

Figure 25. Cartograms indicating streamgages with peak-streamflow qualification code $D$ removed (purple squares, see table 10) or added (green diamonds). 


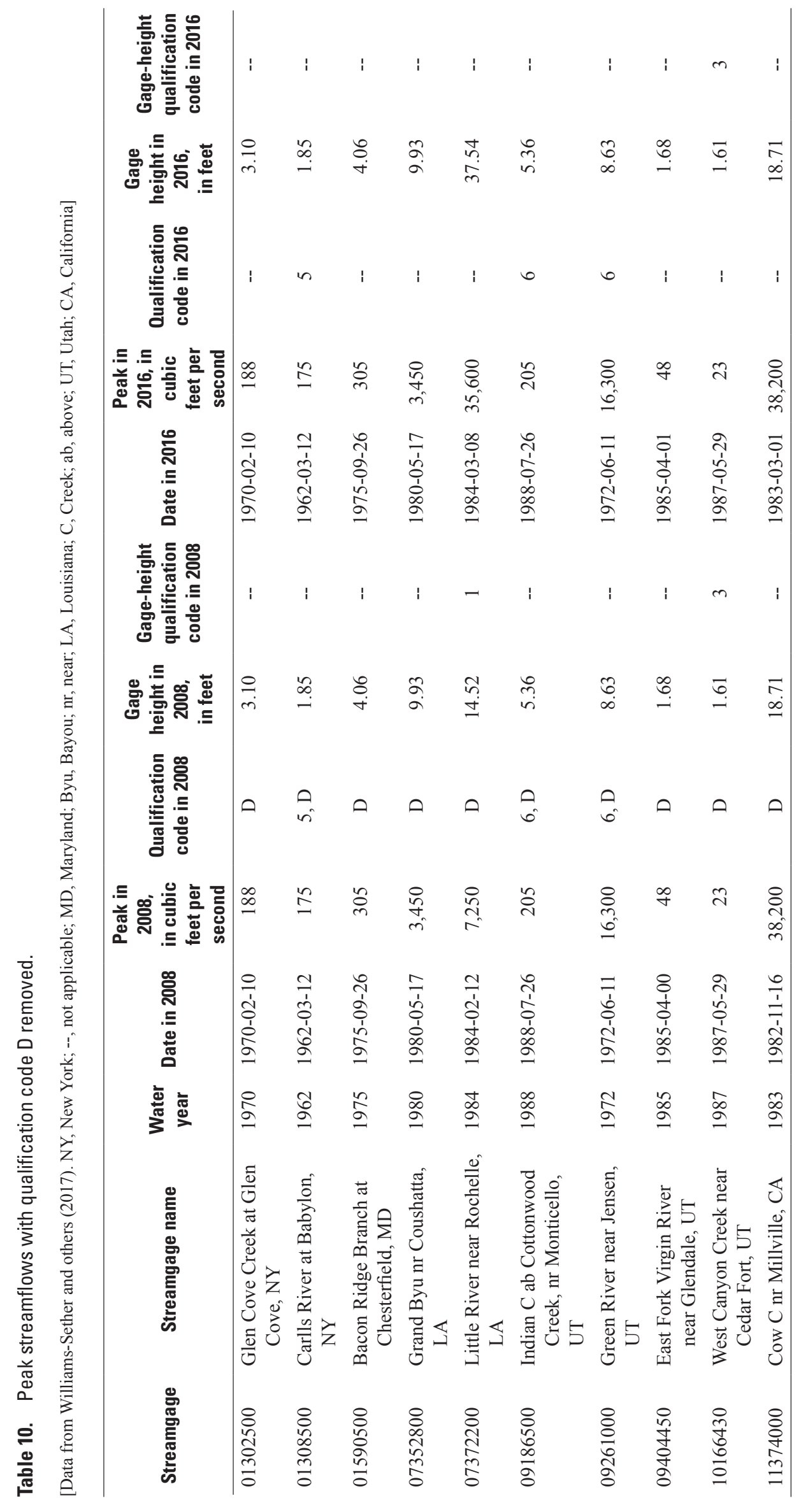


$\because$
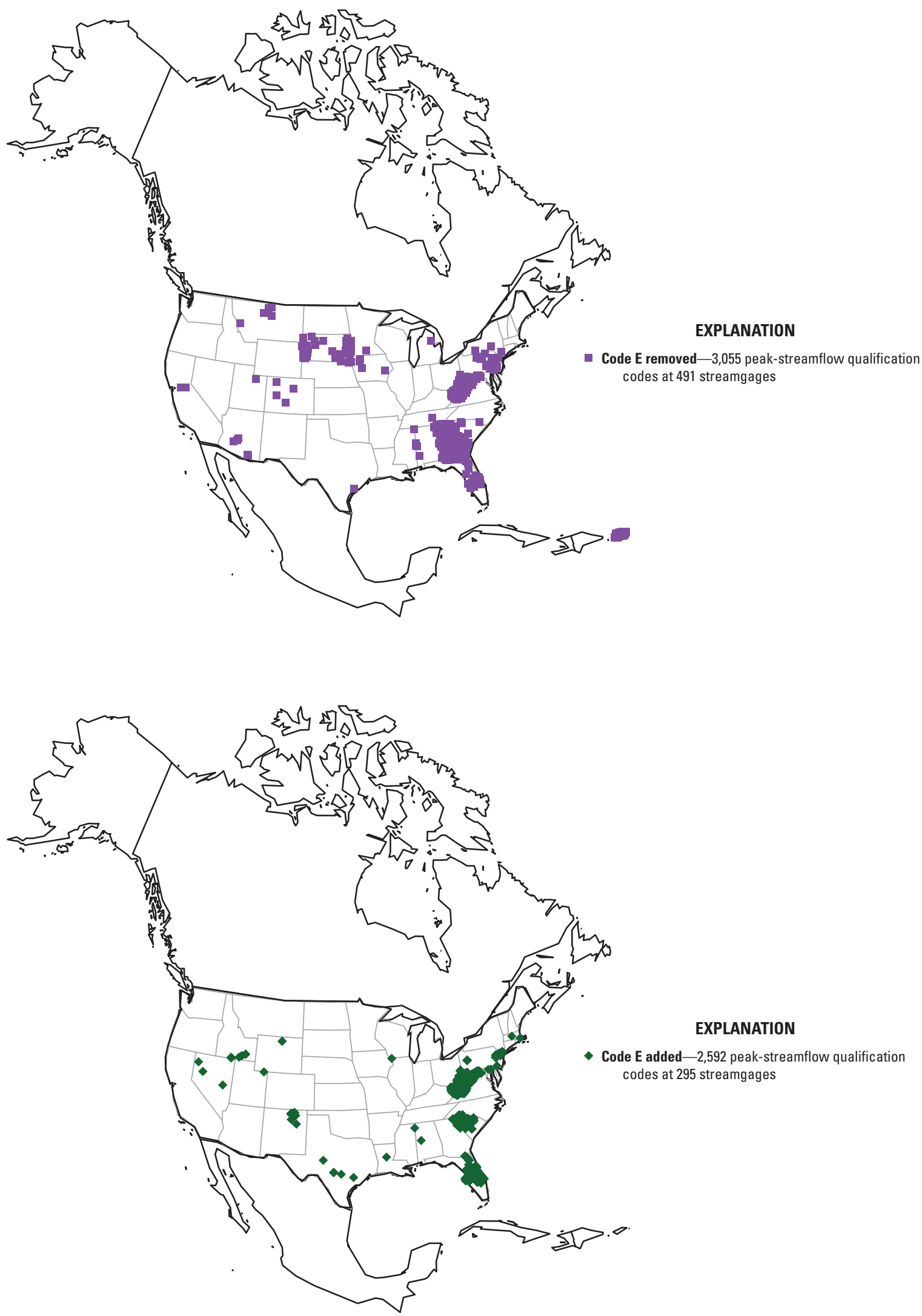

EXPLANATION

$\because$ codes at 295 streamgages

Figure 26. Cartograms indicating streamgages with peak-streamflow qualification code E removed (purple squares) or added (green diamonds). 


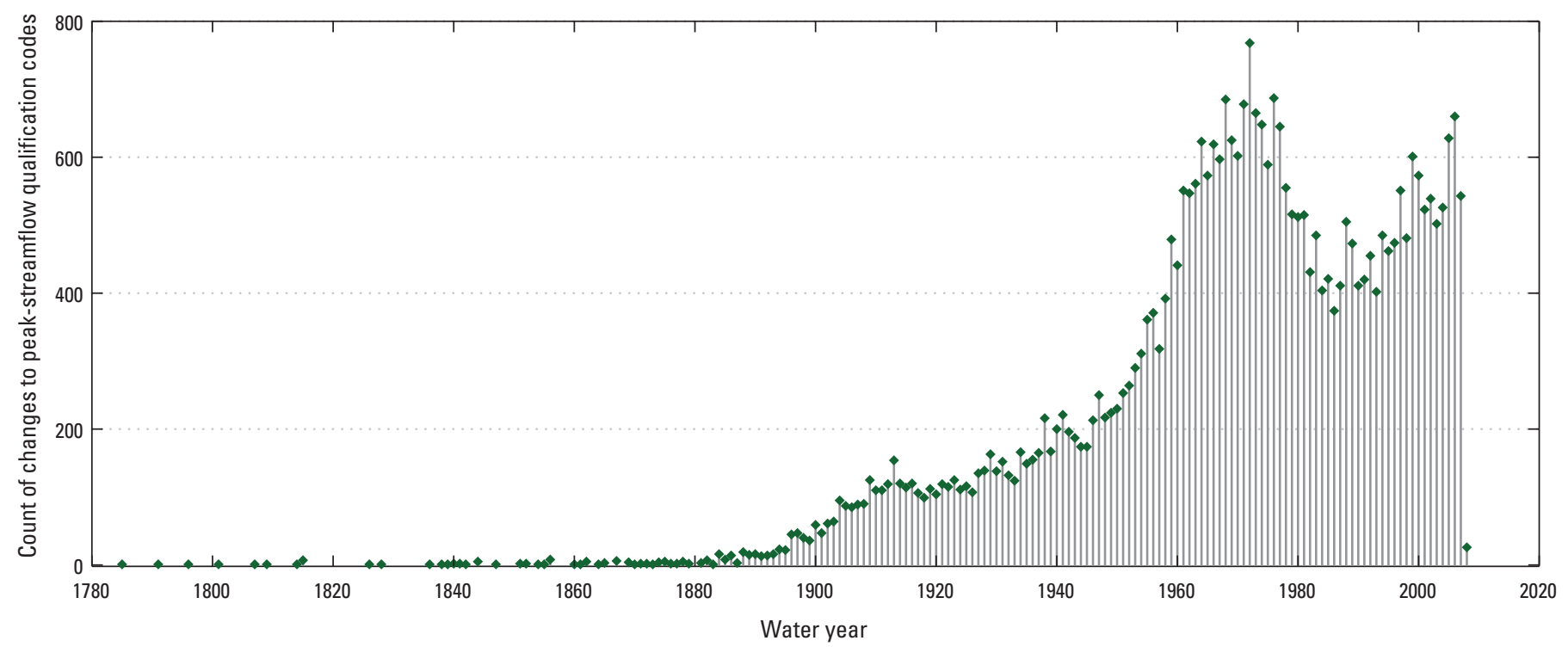

Figure 27. Count of changes to peak-streamflow qualification codes by water year 
$\because$
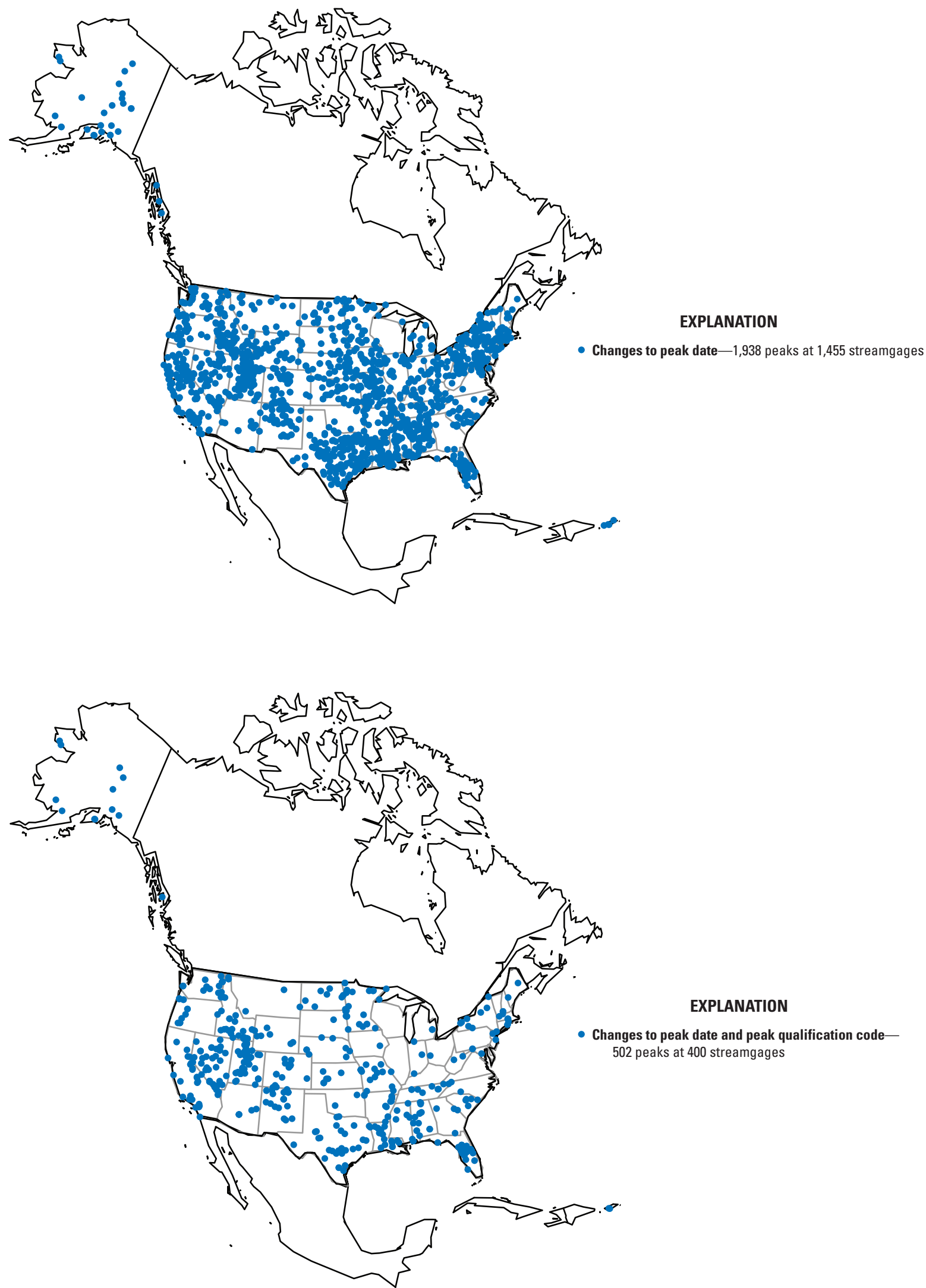

Figure 28. Cartograms indicating streamgages with changes to peak date and changes to peak date and peak-streamflow qualification code. 


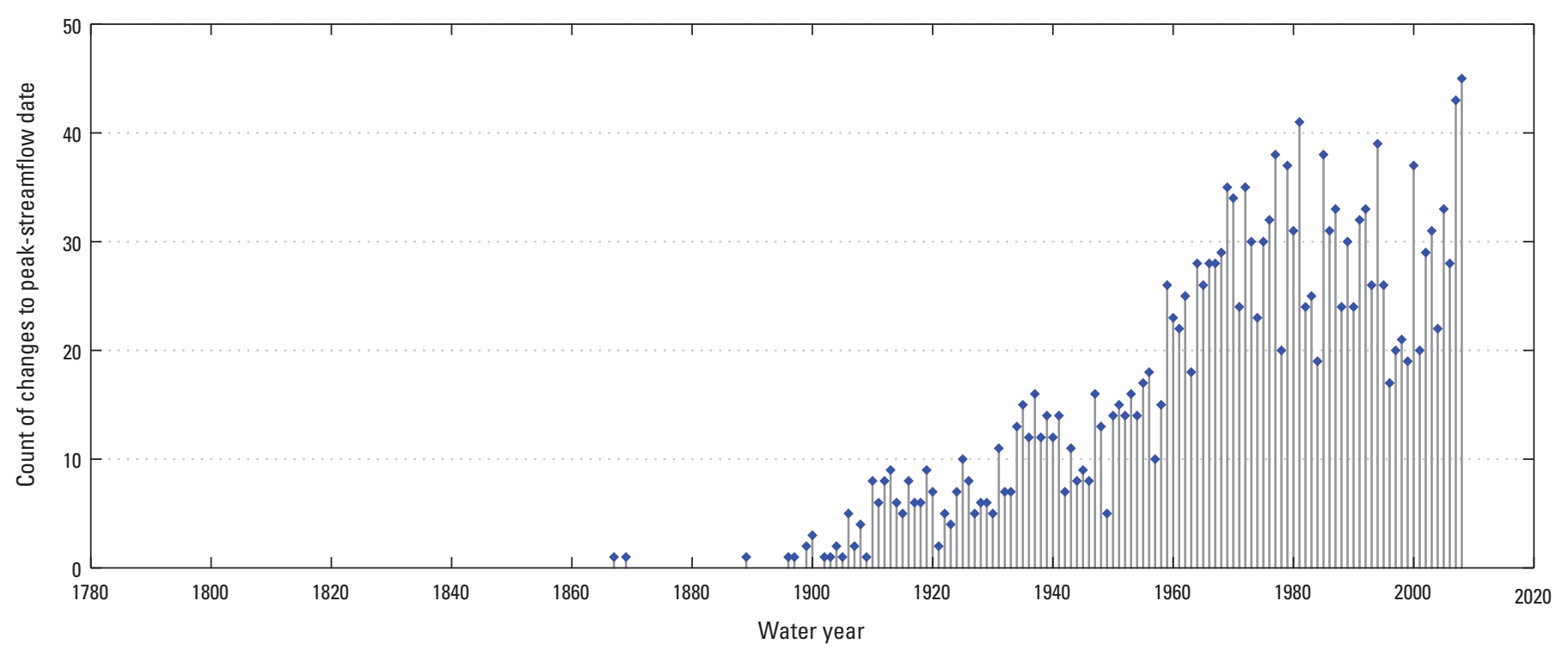

Figure 29. Count of changes to peak date by water year.

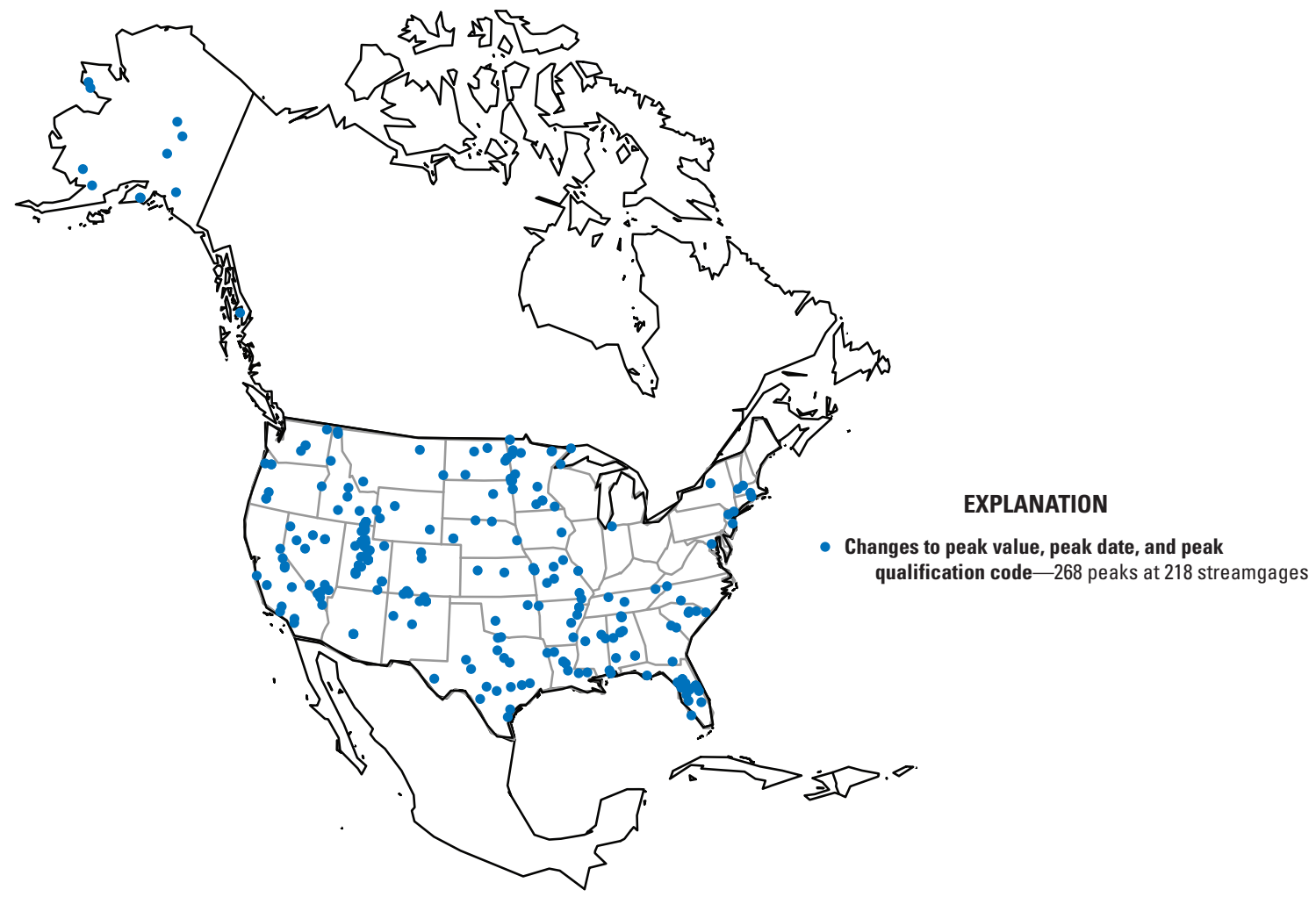

Figure 30. Cartogram indicating streamgages with changes to peak streamflow, peak date, and peak-streamflow qualification code. 
'
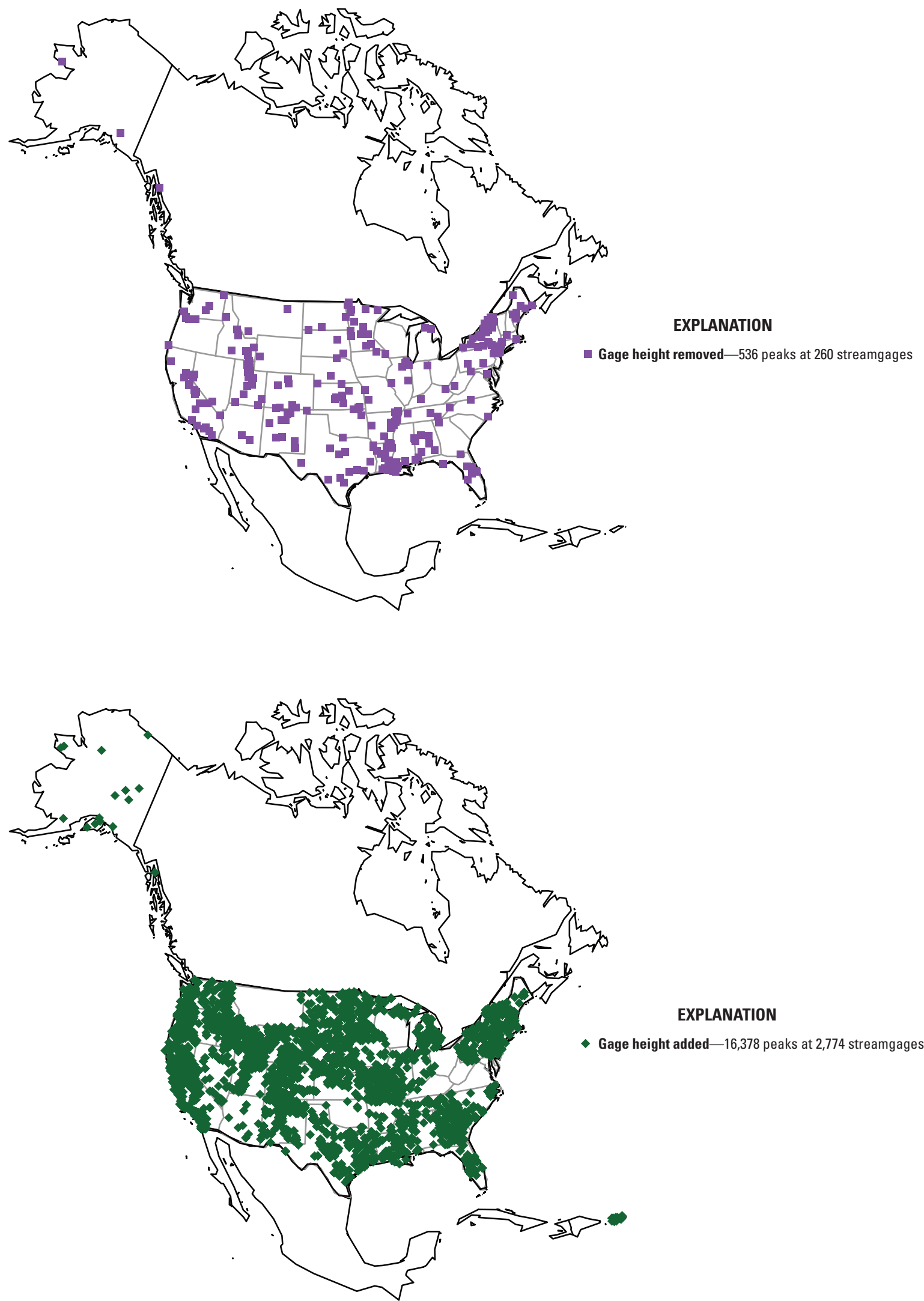

Figure 31. Cartograms indicating streamgages with gage height removed (purple squares) or added (green diamonds). 

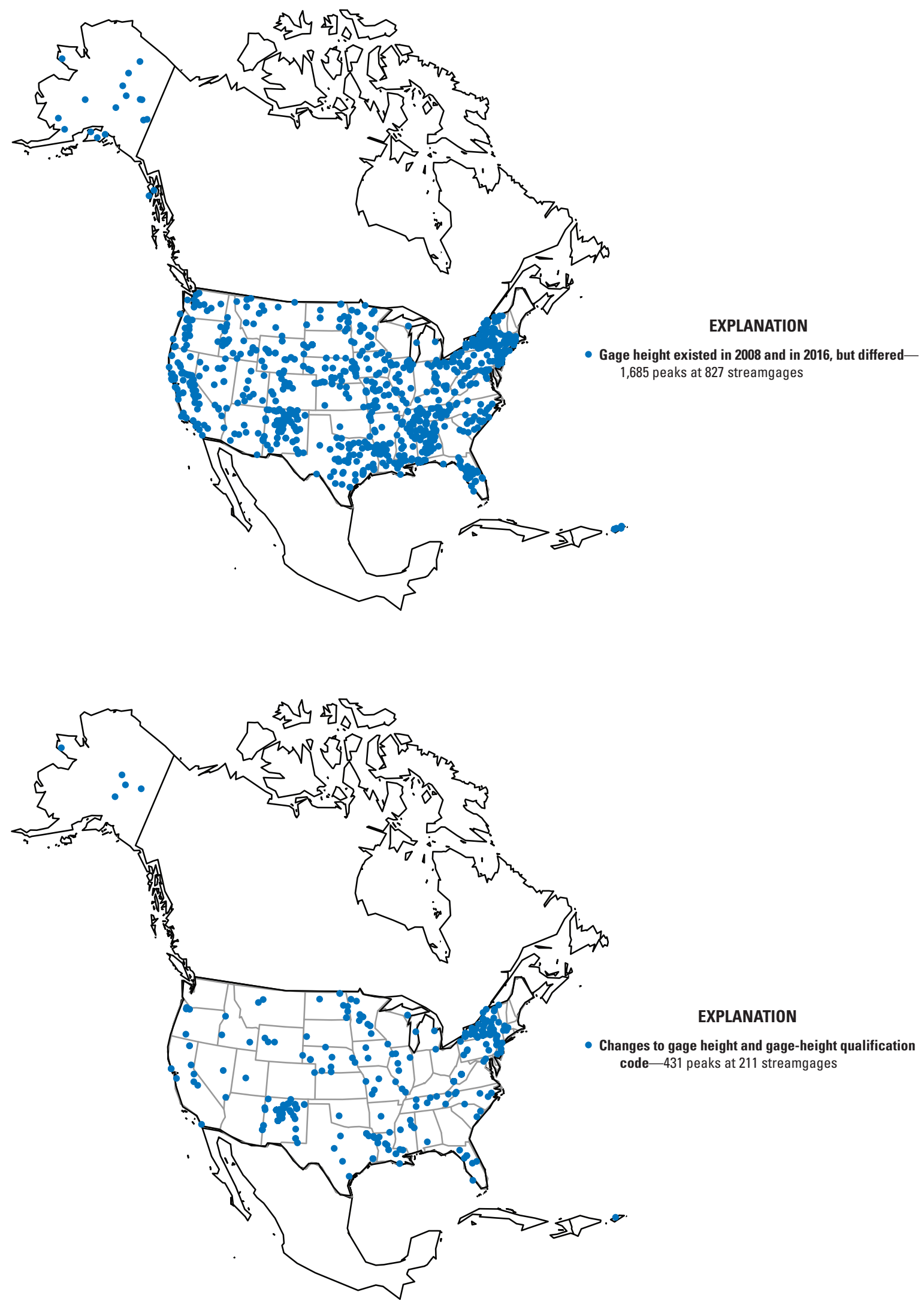

Figure 32. Cartograms indicating streamgages for which gage height existed in 2008 and 2016, but values differed, and streamgages with changes to gage height and gage-height qualification code. 


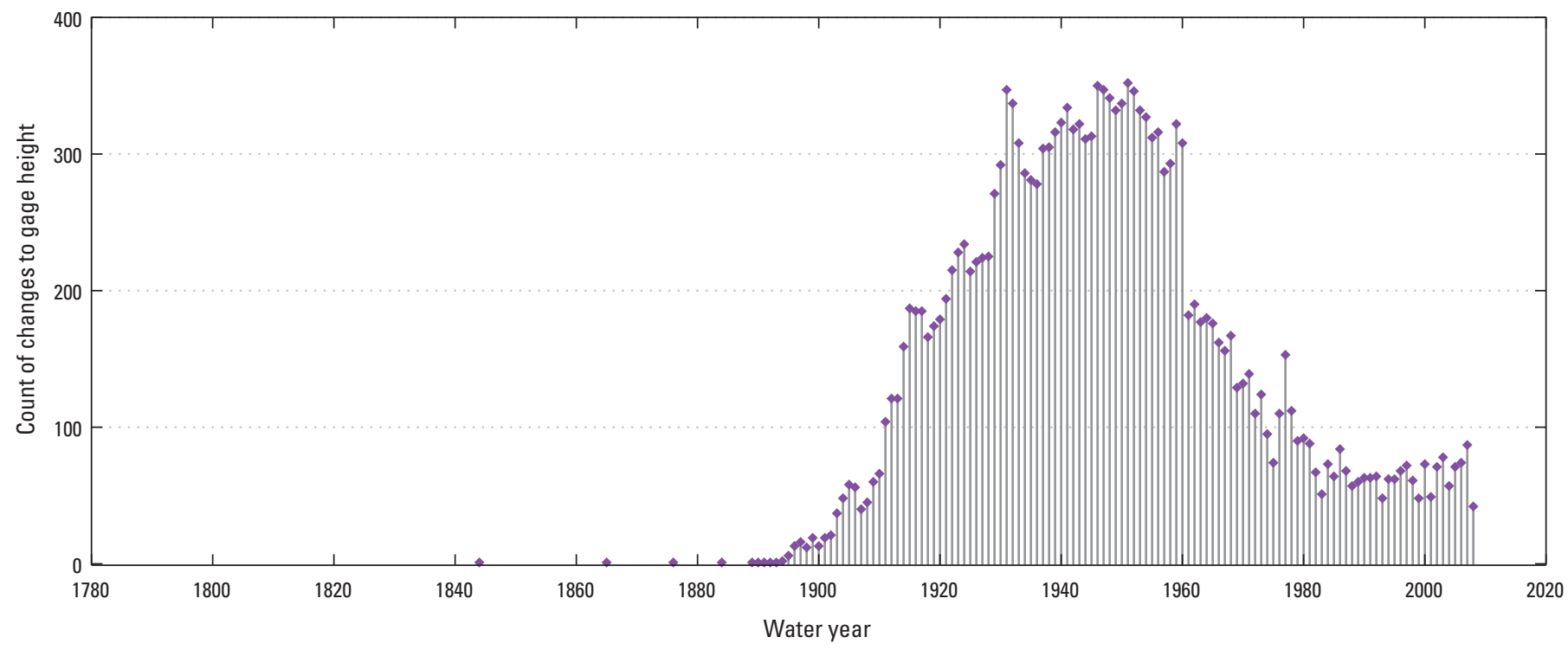

Figure 33. Count of changes to gage height by water year. 

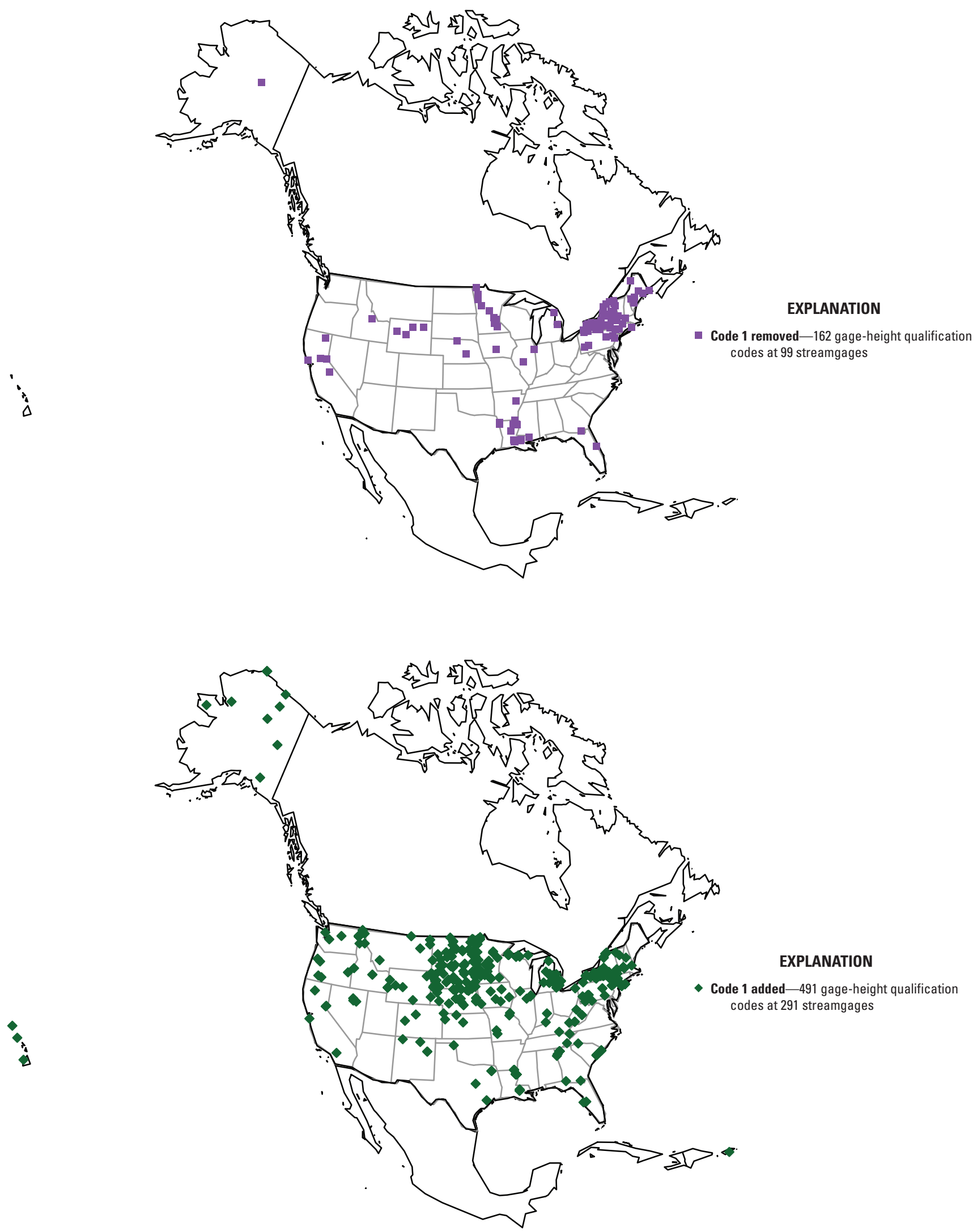

Figure 34. Cartograms indicating streamgages with gage-height qualification code 1 removed (purple squares) or added (green diamonds). 
$\because$

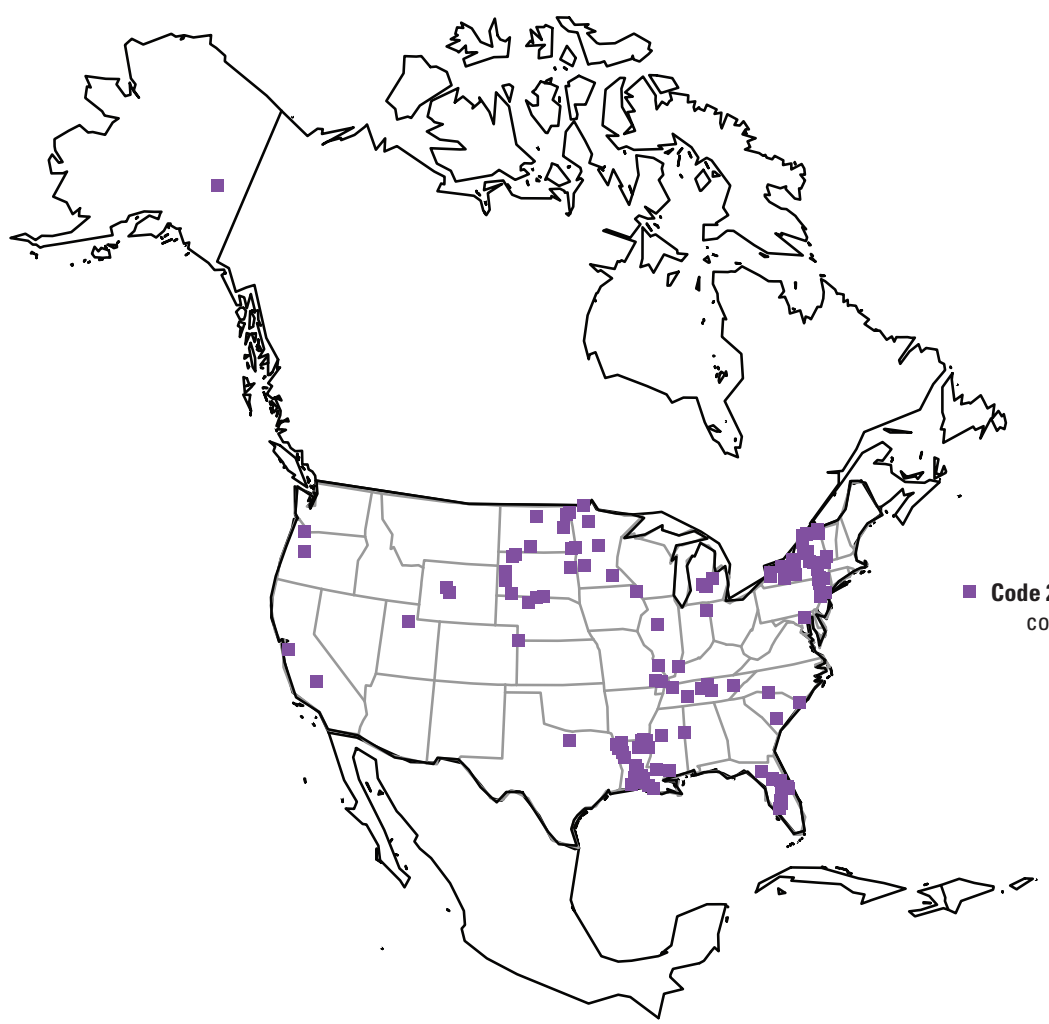

EXPLANATION

Code 2 removed -248 gage-height qualification codes at 123 streamgages

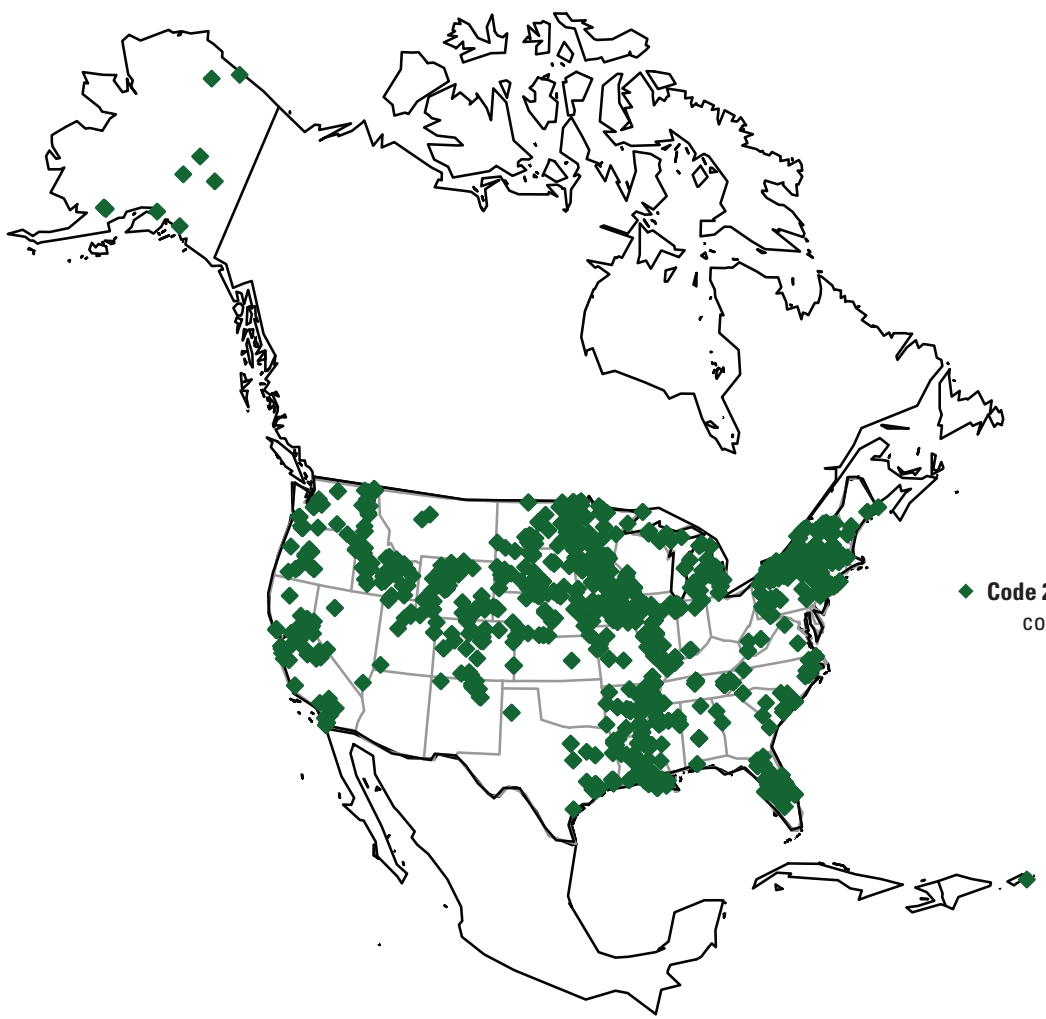

EXPLANATION

-1,938 gage-height qualificatio

$\because$ codes at 822 streamgages

Figure 35. Cartograms indicating streamgages with gage-height qualification code 2 removed (purple squares) or added (green diamonds). 

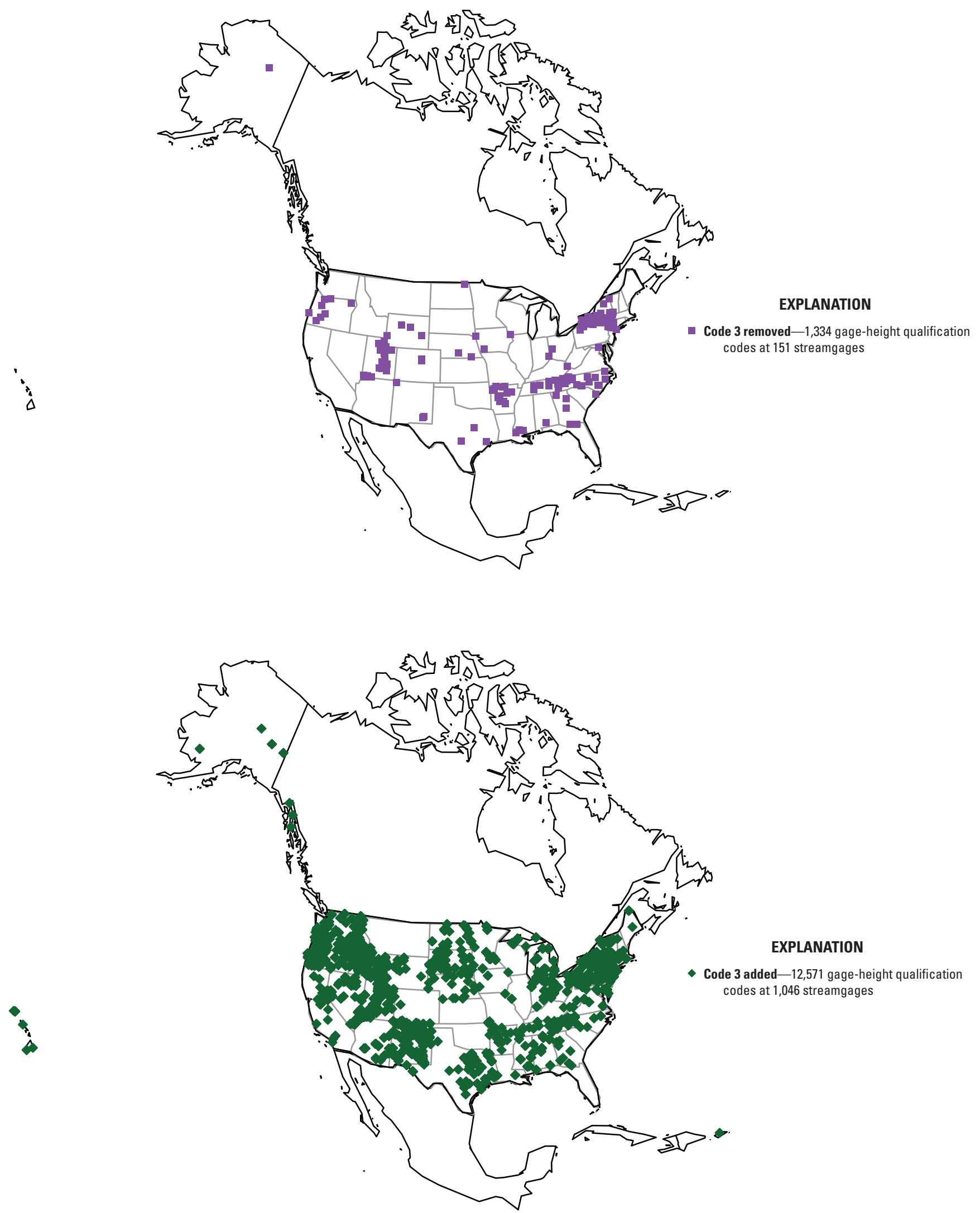

Figure 36. Cartograms indicating streamgages with gage-height qualification code 3 removed (purple squares) or added (green diamonds). 
$\because$
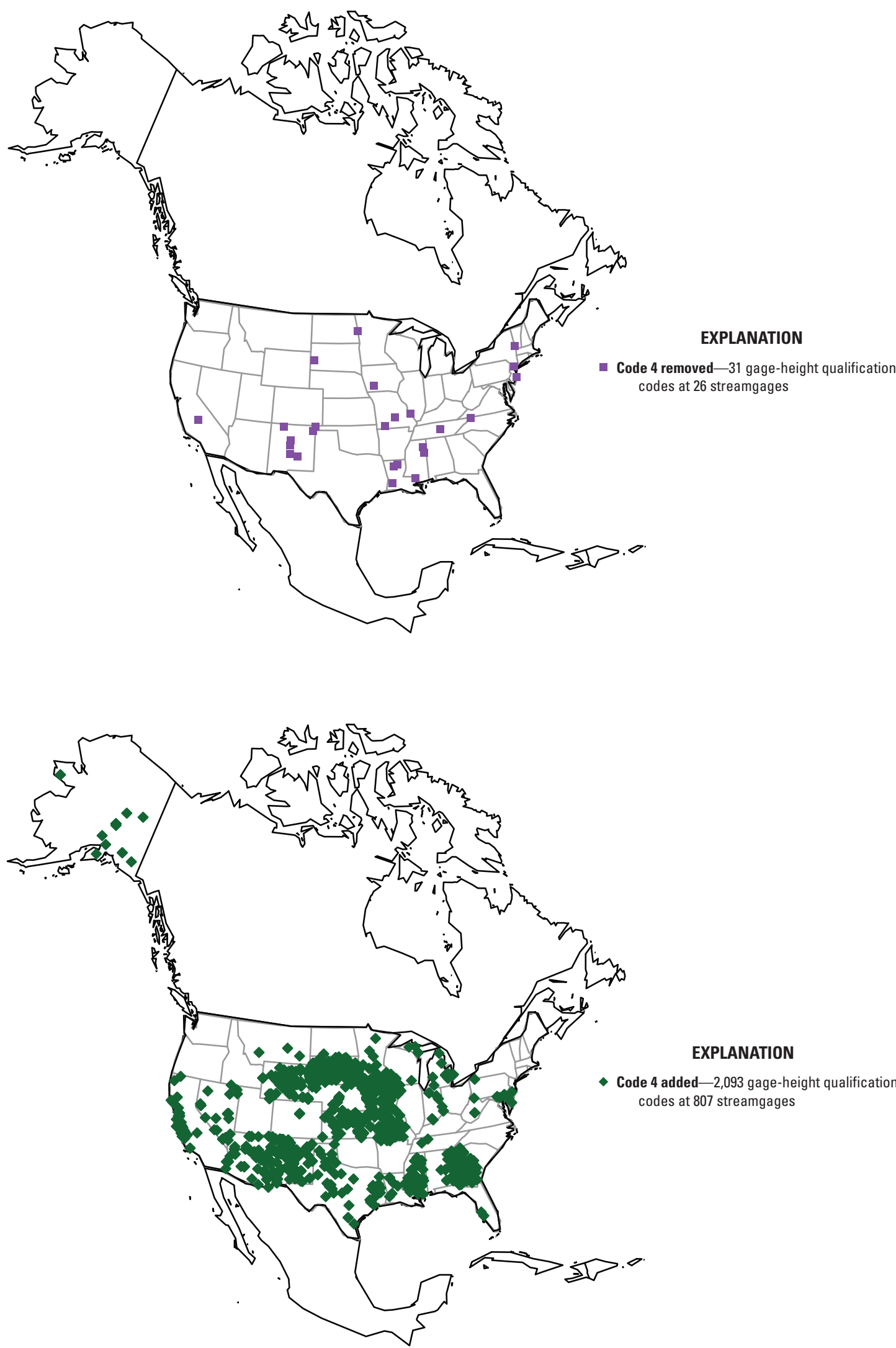

EXPLANATION

-2,093 gage-height qualification codes at 807 streamgages

Figure 37. Cartograms indicating streamgages with gage-height qualification code 4 removed (purple squares) or added (green diamonds). 

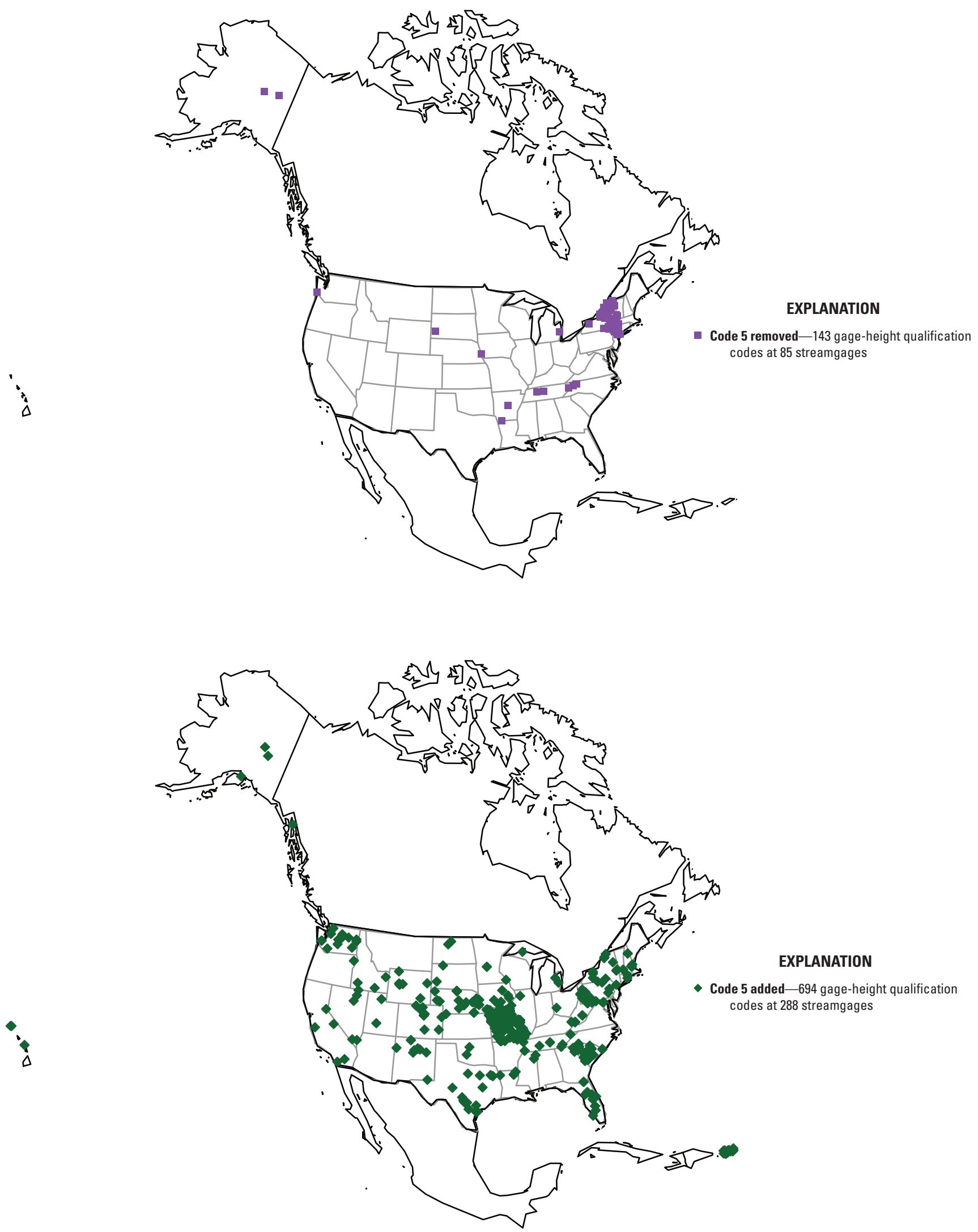

EXPLANATION

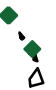
codes at 288 streamgages

Figure 38. Cartograms indicating streamgages with gage-height qualification code 5 removed (purple squares) or added (green diamonds). 
$\because$

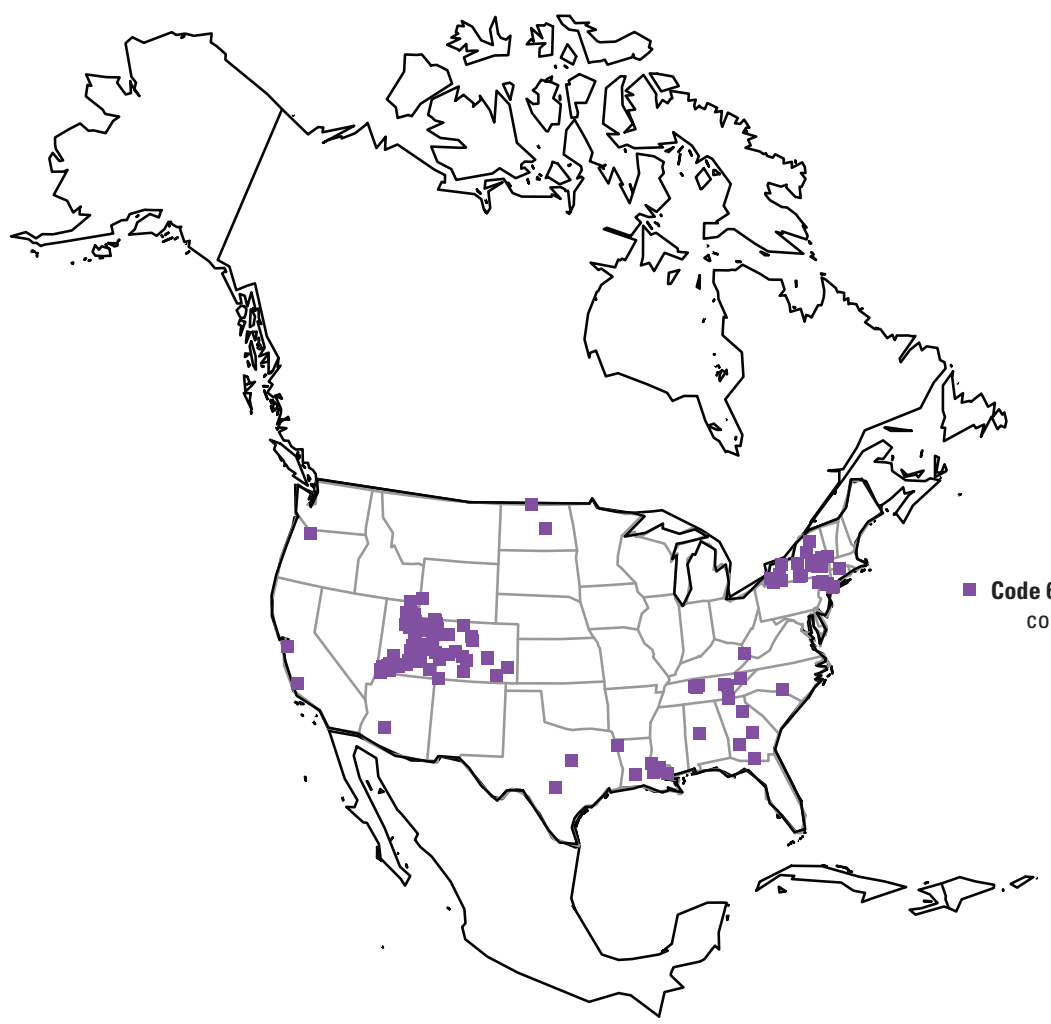

EXPLANATION codes at 132 streamgages

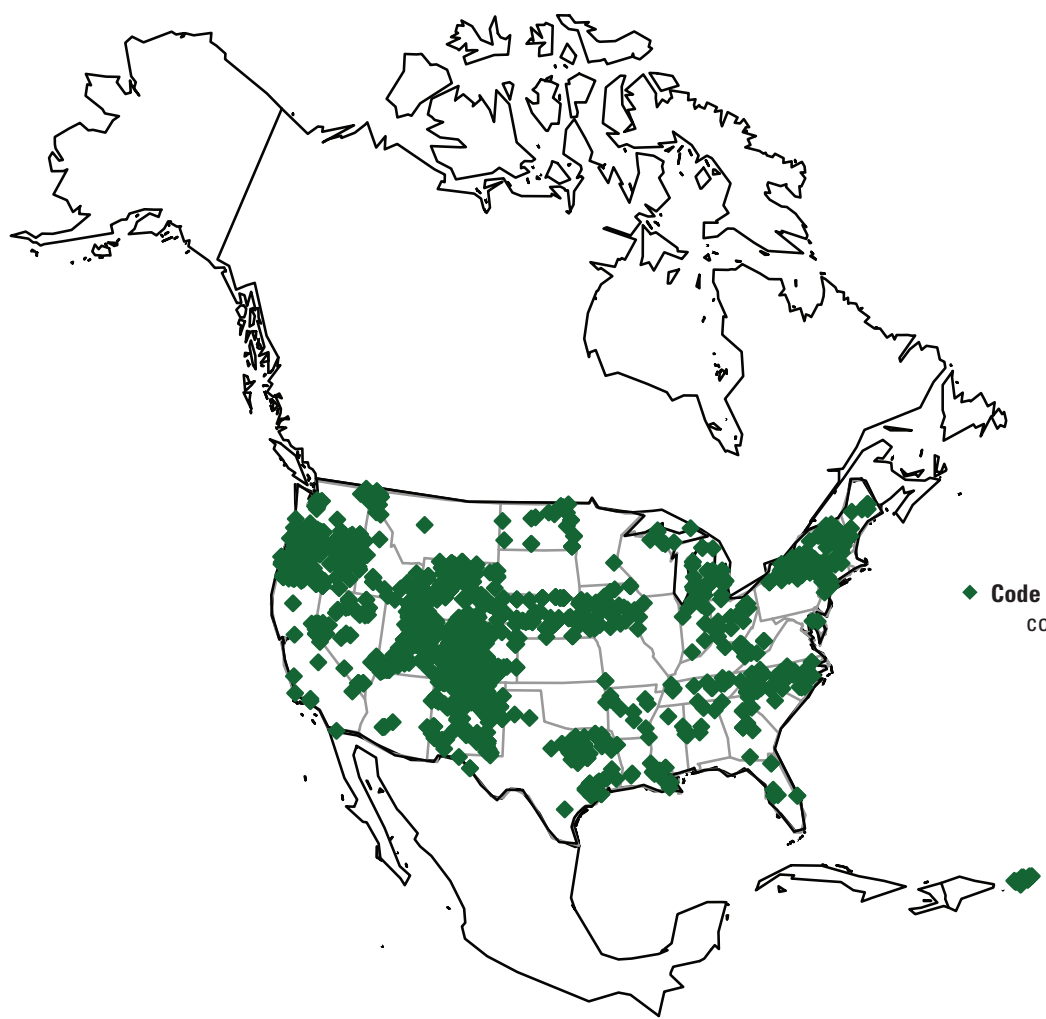

EXPLANATION codes at 1,285 streamgages

Figure 39. Cartograms indicating streamgages with gage-height qualification code 6 removed (purple squares) or added (green diamonds). 


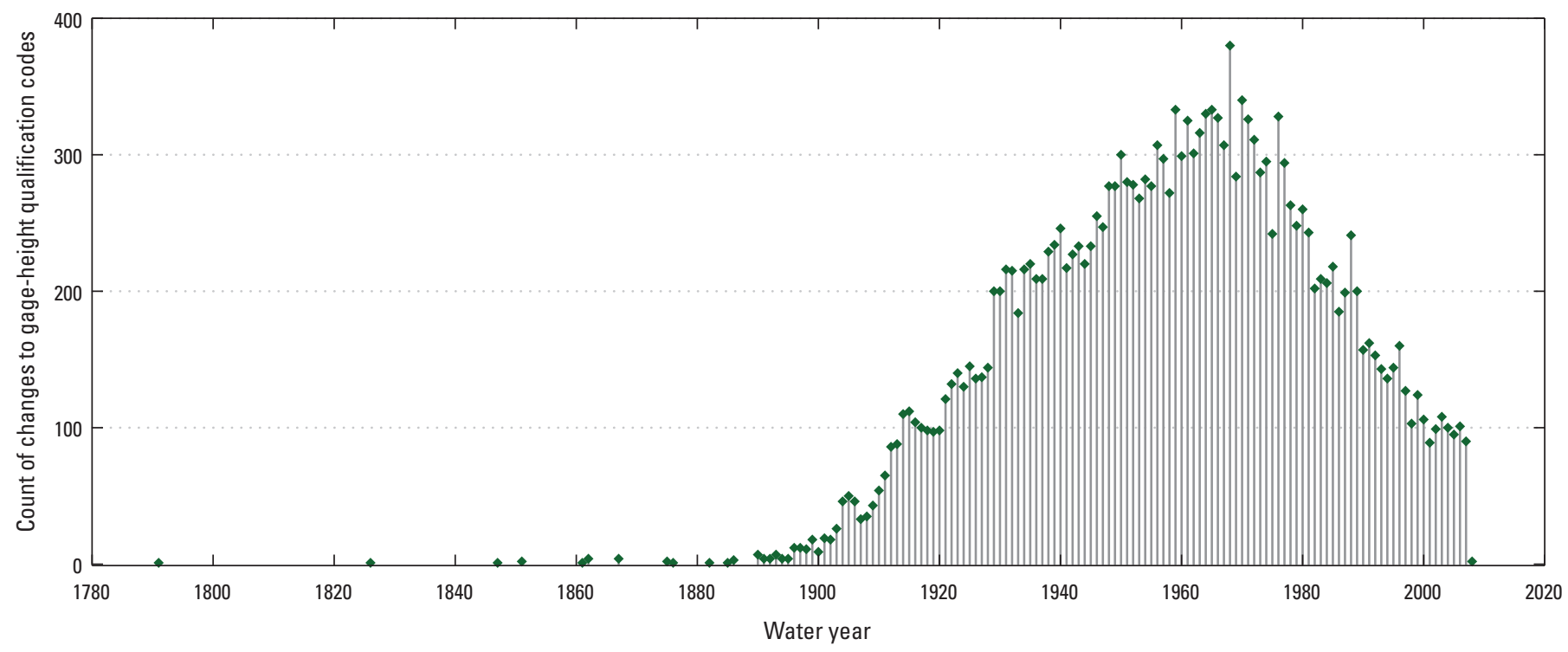

Figure 40. Count of changes to gage-height qualification codes by water year.

\section{All Changes}

The count per year of all peaks with any kind of change (peak flow, peak date, peak-streamflow qualification code, gage height, or gage-height qualification code) is summarized in figure 41.

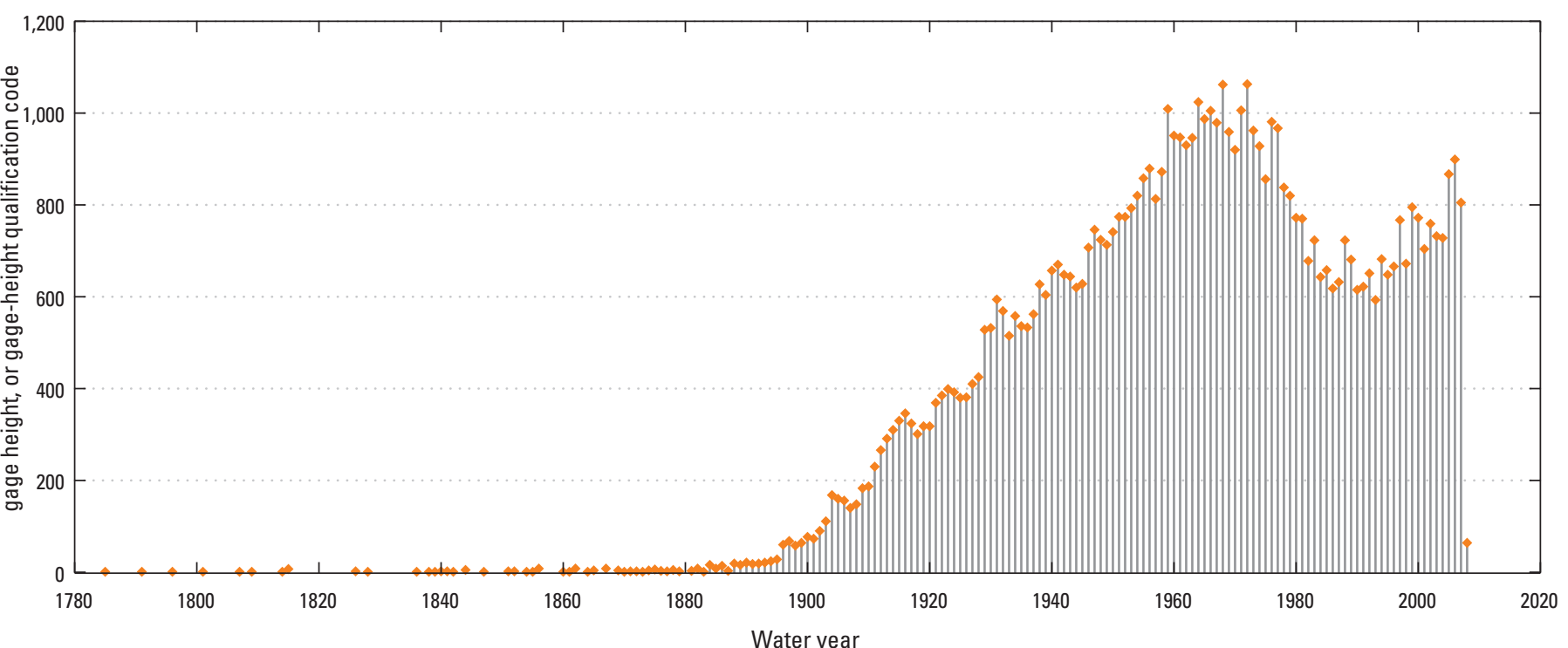

Figure 41. Count of changes to peak streamflow, peak date, peak-streamflow qualification code, gage height, or gage-height qualification code by water year. 


\section{Summary}

Annual peak streamflow (peak flow) at a streamgage is defined as the maximum instantaneous flow in a water year. The accuracy, characterization, and completeness of the data are critical in determining flood-frequency estimates that are used daily to design water and transportation infrastructure, delineate flood-plain boundaries, and regulate development and utilization of lands throughout the Nation and are essential to understanding the implications of climate and land-use change on flooding and high-flow conditions. On November 14, 2016, peak flow existed for 27,240 unique streamgages in the United States and its territories. The data are publicly available as part of the U.S. Geological Survey public web interface, the National Water Information System, at https://nwis.waterdata.usgs.gov/usa/nwis/peak.

In 2008, systematic, nationwide checks of the data began because past internal U.S. Geological Survey surface-water reviews indicated that peak-flow data for many streamgages had one or more problems associated with the peakstreamflow qualification codes, the gage-height values, the streamflow values, or the peak date. Checks were standardized and documented in a program, PFReports, to find potential errors in peak-streamflow values, peak dates, gage heights, and peak-streamflow qualification codes; gage-height qualification codes were indirectly checked. The effort also involved a new user interface, PKEntry, to facilitate corrections and document changes and reasoning for changes. Since 2008, many changes have been made to peak-flow values, gage heights, and qualification codes.

Data representing the November 19, 2008, and the November 14, 2016, U.S. Geological Survey peak-flow file were compared for this report and made available as a U.S. Geological Survey data release. The data can be used to indicate changes to the peak-flow file resulting from dataentry errors, data-processing errors, and data-collection errors. These changes resulted from specific checks of peak-streamflows, peak dates, gage heights, peak-streamflow qualification codes, and gage-height qualification codes.

There were 659,332 peaks in the November 19, 2008, dataset and 731,965 peaks in the November 14, 2016, dataset. The number of changes to peak-flow values from 2008 to 2016 was 5,179 (or 0.79 percent of the 2008 peaks). Of these changes in peak-flow values, 2,638 ( 0.40 percent $)$ were changed to a smaller value and 2,541 (0.39 percent) were changed to a larger value. Peak-streamflow qualification codes changed for 36,506 peaks (5.54 percent). Peak dates were changed for 1,938 peaks ( 0.29 percent). Gage heights changed for 18,599 peaks (2.82 percent), and the gage-height qualification codes changed for 20,683 peaks (3.14 percent). The various types of changes were summarized and mapped to provide users with quantitative and visual documentation of the changes.

\section{Acknowledgments}

Many U.S. Geological Survey staff contributed ideas for the checks of the peak-flow file, including but not limited to Joseph Nielsen, Lamar Sanders (retired), and Larry Bohman. Others examined the results of early testing and helped refine the scripts, including Richard Verdi, Gregg Wiche, and Steve Robinson; however, the authors are most indebted to the scientists and hydrographers in each U.S. Geological Survey Water Science Center (WSC) who reviewed the check results, interpreted the streamgage- and WSC-specific results, and labored to identify and correct errors detected by the programs or, conversely, confirmed the reliability of data that may have been incorrectly flagged. Their efforts, past, present, and future, have resulted in, and will enrich, a robust peak-streamflow dataset that is essential to the ongoing design, development, operation, and renewal of much of the infrastructure in the United States and its territories.

\section{References Cited}

Asquith, W.H., Kiang, J.E., and Cohn, T.A., 2017, Application of at-site peak-streamflow frequency analyses for very low annual exceedance probabilities: U.S. Geological Survey Scientific Investigations Report 2017-5038, 93 p. [Also available at https://doi.org/10.3133/sir20175038.]

Barnes, H.H., and Golden, H.G., 1966, Magnitude and frequency of floods in the United States, pt. 2-B, South Atlantic slope and Eastern Gulf of Mexico basins, Ogeechee River to Pearl River: U.S. Geological Survey Water-Supply Paper 1674, 409 p. [Also available at https://pubs.er.usgs. gov/publication/wsp1674.]

Benson, M.A., 1962, Factors influencing the occurrence of floods in a humid region of diverse terrain: U.S. Geological Survey Water-Supply Paper 1580-B, 64 p., accessed March 3, 2017, at https://pubs.usgs.gov/wsp/1580b/ report.pdf.

Curran, J.H., Barth, N.A., Veilleux, A.G., and Ourso, R.T., 2016, Estimating flood magnitude and frequency at gaged and ungaged sites on streams in Alaska and conterminous basins in Canada, based on data through water year 2012: U.S. Geological Survey Scientific Investigations Report 2016-5024, 47 p. [Also available at https://doi.org/10.3133/ sir20165024.] 
Flynn, K.M., Kirby, W.H., and Hummel, P.R., 2006, User's manual for program PeakFQ, annual flood-frequency analysis using Bulletin 17B guidelines: U.S. Geological Survey Techniques and Methods, book 4, chap. B4; 42 p. [Also available at https://pubs.er.usgs.gov/publication/tm4B4.]

Green, A.R., 1964, Magnitude and frequency of floods in the United States, Part 1-A, North Atlantic Basins, Maine to Connecticut: U.S. Geological Survey Water-Supply Paper 1671, 260 p. [Also available at https://pubs.er.usgs.gov/ publication/wsp1671.]

Hirsch, R.M., and De Cicco, L.A., 2015, User guide to Exploration and Graphics for RivEr Trends (EGRET) and dataRetrieval - R packages for hydrologic data (version 2.0, February 2015): U.S. Geological Survey Techniques and Methods, book 4, chap. A10, 93 p. [Also available at https:// doi.org/10.3133/tm4A10.]

Interagency Advisory Committee on Water Data, 1982, Guidelines for determining flood flow frequency: Bulletin 17B of the Hydrology Subcommittee, Office of Water Data Coordination, U.S. Geological Survey, Reston, Va., 183 p. [Also available at https://water.usgs.gov/osw/bulletin17b/ bulletin_17B.html.]

Murphy, E.C., 1906, Destructive floods in the United States in 1905, with a discussion of flood discharge and frequency and an index to flood literature: U.S. Geological Survey Water-Supply and Irrigation Paper 162, 105 p. [Also available at https://pubs.er.usgs.gov/publication/wsp162.]

Novak, C.E., 1985, WRD data reports preparation guide: U.S. Geological Survey Open-File Report 85-480, 331 p. [Also available at https://pubs.er.usgs.gov/publication/ ofr85480.]

Patterson, J.L., 1966, Magnitude and frequency of floods in the United States, pt. 6-A, Missouri River Basin above Sioux City, Iowa: U.S. Geological Survey Water-Supply Paper 1679, 471 p. [Also available at https://pubs.er.usgs.gov/publication/wsp1679.]

Patterson, J.L., and Gamble, C.R., 1968, Magnitude and frequency of floods in the United States, pt. 5, Hudson Bay and Upper Mississippi River Basins: U.S. Geological Survey Water-Supply Paper 1678, 546 p. [Also available at https://pubs.er.usgs.gov/publication/wsp1678.]

R Core Team, 2016, R-A language and environment for statistical computing: R Foundation for Statistical Computing, Vienna, Austria, accessed July 31, 2017, at https://www.R-project.org/.
Ryberg, K.R., 2008, PFReports-A program for systematic checking of annual peaks in NWISWeb: U.S. Geological Survey Open-File Report 2008-1284, 17 p. [Also available at https://pubs.usgs.gov/of/2008/1284/.]

Ryberg, K.R., and Nielsen, J.P, 2014, Improvements to peak flow file validation tests and reports: Office of Surface Water Informational and Technical Note 2015.03, November 6, 2014, 2 p. [Also available at https://xcollaboration. usgs.gov/wg/osw/OSWNotes/FY2015\%20Notes/OSW\%20 Note $\% 202015.03 \% 20$ Improvements $\% 20$ to\%20Peak\%20 Flow\%20File\%20Validation\%20Tests\%20and\%20Reports. pdf.]

Speer, P.R., and Gamble, C.R., 1964a, Magnitude and frequency of floods in the United States, pt. 2-A, South Atlantic slope basins, James River to Savannah River: U.S. Geological Survey Water-Supply Paper 1673, 329 p. [Also available at https://pubs.er.usgs.gov/publication/wsp1673.]

Speer, P.R., and Gamble, C.R., 1964b, Magnitude and frequency of floods in the United States, pt. 3-B: U.S. Geological Survey Water-Supply Paper 1676, 340 p. [Also available at https://pubs.er.usgs.gov/publication/wsp1676.]

Speer, P.R., and Gamble, C.R., 1965, Magnitude and frequency of floods in the United States, pt. 3-A, Ohio River Basin except Cumberland and Tennessee River Basins: U.S. Geological Survey Water-Supply Paper 1675, 630 p. [Also available at https://pubs.er.usgs.gov/publication/ wsp1675.]

Tice, R.H., 1968, Magnitude and frequency of floods in the United States, pt. 1-B, North Atlantic slope basins, New York to York River: U.S. Geological Survey Water-Supply Paper 1672, 585p. [Also available at https://pubs.er.usgs.gov/publication/wsp1672.]

U.S. Geological Survey, 1962, Surface water records of Colorado: U.S. Geological Survey Water Data Report CO-62-1, 335 p. [Also available at https://pubs.er.usgs.gov/ publication/wdrCO621.]

U.S. Geological Survey, 1992, Guidelines for identifying and evaluating peak discharge errors: Office of Surface Water Technical Memorandum 92.10, accessed July 31, 2017, at https://water.usgs.gov/admin/memo/SW/sw92.10.html.

U.S. Geological Survey, 2008, Review and correction of the peak flow file: OSW Technical Memorandum 09.01, 6 p. [Also available at https://water.usgs.gov/admin/memo/SW/ sw09.01.pdf.] 
U.S. Geological Survey, 2017a, Current Conditions for the Nation: U.S. Geological Survey National Water Information System database, accessed September 24, 2017, at https://waterdata.usgs.gov/nwis/ current?agency_cd=USGS\&site_tp_cd=ST\&index_ pmcode_STATION_NM=1\&index_pmcode DATETIME $=2 \&$ index_pmcode_00060 $=1 \& \overline{\text { format }}=$ station list\&group_key=NONE\&sort_key_2 $=$ site_no\&html_table group_key $=\mathrm{NONE} \& \mathrm{rdb} \_$compression $=$file\&list_of_search_ criteria=agency_cd $\% 2$ Csite_tp_cd $\% 2$ Crealtime_parameter_ selection. [Also available at https://doi.org/10.5066/ F7P55KJN.]

U.S. Geological Survey, 2017b, Peak streamflow for the Nation: National Water Information System-Web interface, accessed January 20, 2017, at https://doi.org/10.5066/ F7P55KJN.

Veilleux, A.G., Cohn, T.A., Flynn, K.M., Mason, R.R., Jr., and Hummel, P.R., 2013, Estimating magnitude and frequency of floods using PeakFQ 7.0 program: U.S. Geological Survey Fact Sheet 2013-3108, 2 p. [Also available at https://doi.org/10.3133/fs20133108.]

Wiitala, S.W., 1965, Magnitude and frequency of floods in the United States, pt. 4: U.S. Geological Survey Water-Supply Paper 1677, 357 p. [Also available at https://pubs.er.usgs.gov/publication/wsp1677.]

Williams-Sether, Tara, Ryberg, K.R., and Goree, B.B., 2017, Data documenting the U.S. Geological Survey peak-flow file data verification project, 2008-16: U.S. Geological Survey data release, https://doi.org/10.5066/F7GH9G3P. 


\section{Appendix 1. U.S. Geological Survey Surface Water Branch Technical Memorandum 69.11—Storage and Retrieval System for Annual Peak Discharges}

Several Office of Surface Water (formerly Surface Water Branch) memorandums are referenced in this report. Most of the memorandums are available online (https://water.usgs.gov/admin/memo/SW/); however, this one, written in 1969, is not available online and was scanned and made available at https://doi.org/10.3133/sir20175119 so that there is an electronic copy. 


\section{Appendix 2. Code that Produced the Results}

The R (R Core Team, 2016) code available at https://doi.org/10.3133/sir20175119 may be run to replicate the numerical and graphical results in the report. The code may be viewed in most text editors.

\section{Reference Cited}

R Core Team, 2016, R-A language and environment for statistical computing: R Foundation for Statistical Computing, Vienna, Austria, accessed July 31, 2017, at https://www.R-project.org/. 
For additional information concerning this publication, contact: Director, USGS Office of Surface Water

415 National Center

12201 Sunrise Valley Drive

Reston, VA 20192

(703) 648-5301

Or visit the Office of Surface Water website at: https://water.usgs.gov/osw

Publishing support provided by: Rolla Publishing Service Center 


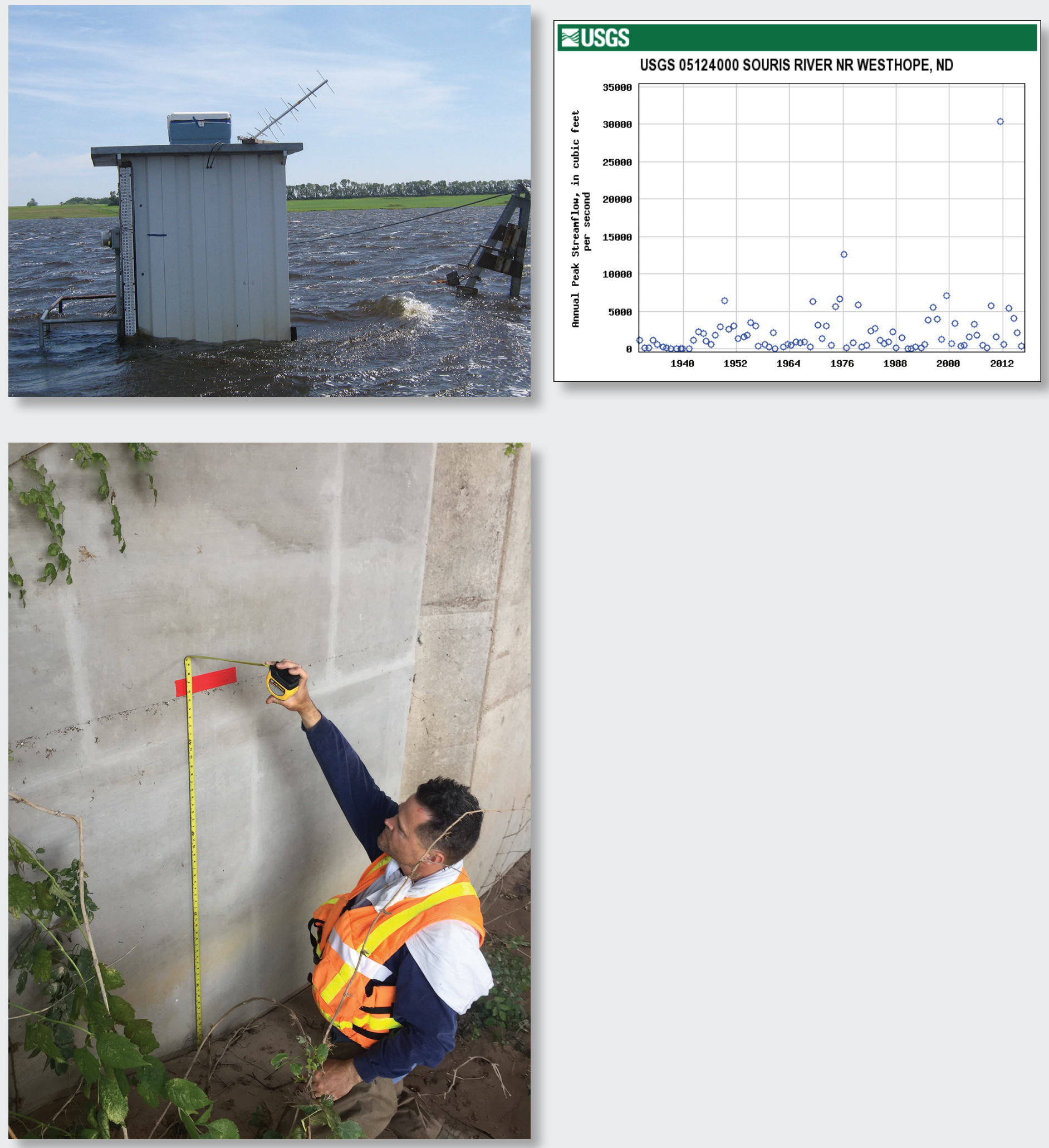

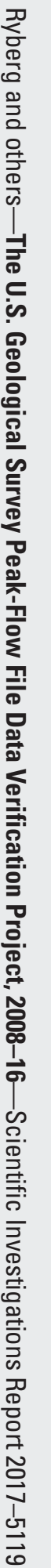

